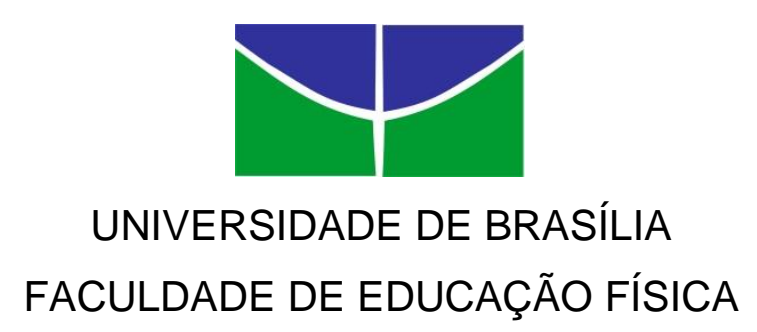

PROGRAMA DE PÓS-GRADUAÇÃO STRICTO-SENSU EM EDUCAÇÃO FÍSICA

\title{
O SACRIFÍCIO NO RITUAL DAS CORRIDAS DE RUA: RELATOS E SIGNIFICADOS DOS PRATICANTES
}

Cláudio José de Arruda

Brasília/DF

2016 
O SACRIFÍCIO NO RITUAL DAS CORRIDAS DE RUA:

RELATOS E SIGNIFICADOS DOS PRATICANTES

CLÁUDIO JOSÉ DE ARRUDA

Dissertação apresentada à Faculdade de Educação Física da Universidade de Brasília, como requisito parcial para obtenção do grau de Mestre em Educação Física.

ORIENTADORA: Prof ${ }^{a}$. DULCE FILGUEIRA DE ALMEIDA 
O SACRIFÍCIO NO RITUAL DAS CORRIDAS DE RUA:

RELATOS E SIGNIFICADOS DOS PRATICANTES

CLÁUDIO JOSÉ DE ARRUDA

Banca Examinadora:

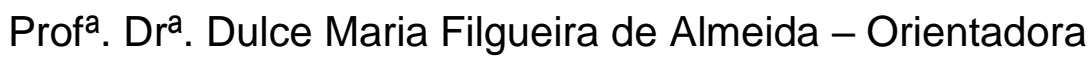

Faculdade de Educação Física - FEF/UnB

Prof. Dr. Luiz Renato Vieira - Membro Externo

Senado Federal/ Consultoria Legislativa

Prof. Dr. Marcelo de Brito

Universidade de Brasília - Suplente

Prof. Dr. Arthur José Medeiros de Almeida - Suplente

Faculdade de Ciências da Educação e Saúde - UniCEUB 


\section{DEDICATÓRIA}

Ao meu "velho" e bom pai, José Paulino de Arruda (in memorian), que dizia a mim, com frequência na minha infância: "vai estudar menino!". Meu grande amigo e companheiro. Ensinou-me a ser responsável e encarar a vida com determinação e simplicidade, preservando boas amizades e a proximidade com a família. No dia de seu falecimento, 07 de julho de 2013, fazíamos o que tanto nos dá prazer: correr! Você foi um bom homem, um bom marido e um bom pai! Esse trabalho é dedicado a você! 


\section{AGRADECIMENTOS}

Ao bom Deus, que desde minha infância o reconheço como Papai do Céu, por ensinamento dos meus pais, por ter me dado a chance de ter saúde e forças para encarar a vida e seus tantos desafios, como o mestrado.

À Eryka Danyelle Silva Galindo, companheira de todas as horas, considerote 'co-orientadora' pessoal deste trabalho, por tamanho respeito e admiração que tenho por sua disciplina, inteligência e rigorosidade com os estudos. Ao longo destes mais de 10 anos, juntos, te admiro e te amo como mulher, forte como és!

À d. Eunice Oliveira de Arruda, minha mãe. À senhora, minha admiração e respeito por tamanha fortaleza! Frágil em momentos difíceis, mas forte e sincera quando necessário. A escrever e a ler, foi você quem me ensinou, bem antes da escola. Aproveito e lhe peço desculpas, pela distância destes anos, mas que não nos afastamos nunca. "Sua bênção, minha mãe!"

À minha irmã querida e amiga, Jaqueline Oliveira, pela paciência e respeito mútuo. Agradeço também pela dedicação e cuidado que tens por sua família e pela nossa família!

Ao meu amigo e também guru acadêmico Enildo Luiz, que com sua dedicação e força de vontade também me ensino a seguir em frente, refletindo e sendo perseverante com os estudos.

Ao amigo e compadre, Renato Fenili e esposa, Giovana Fenili, amigos acolhedores e irmãos por afinidade.

À professora Dulce Almeida que aceitou ser minha orientadora. Desde a primeira disciplina cursada com você, tem meu respeito e admiração pelo acolhimento, carinho e rigorosidade acadêmica.

Aos queridos amigos deste caminho ao longo dos últimos três anos no mestrado, Marisa Melo, que ultrapassando os limites acadêmicos, nos tornamos bons amigos. À Mayrhon Farias, um maranhense determinado a conquistar seus sonhos, um amigo e professor a ser respeitado por sua bondade. À Letícia Teixeira, por seu empenho com a pesquisa e à Ana Amélia, cearense forte e mulher 
guerreira. Agradeço também à Thais Queiroz, responsável por muitas boas sugestões, que foram acolhidas ao longo deste trabalho.

Agradeço ainda à assessoria esportiva Ápice Treinamento Multiesportivo, com seu corpo de professores Rodrigo Albuquerque, Bruno Secundo e Liliane Brito, pelo apoio e paciência ao longo destes anos, quando precisei, muitas vezes, me ausentar do local de trabalho, para poder comparecer às aulas e a outros ambientes na Universidade.

Por fim e não menos especial, à todos os alunos e amigos que me apoiaram ao longo deste processo, trocando figurinhas sobre minha pesquisa e me fazendo reconhecer a importância deste trabalho. À Abel Gilberto, Celizara Silveira, Eva Matos, Marcelo Ávila, Maria Helena e Reinaldo Vergara. Vocês transmitem muita paixão ao falar sobre corrida de rua! 


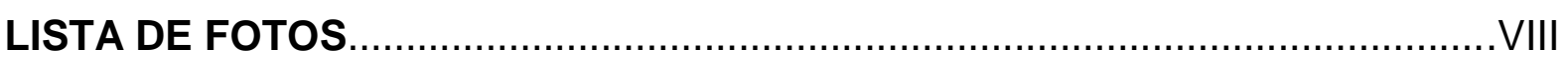

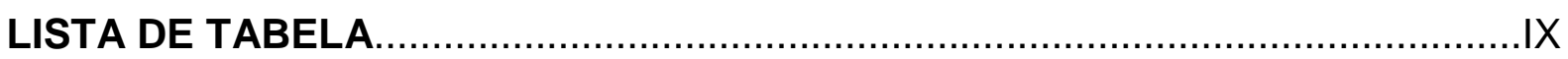

RESUMO

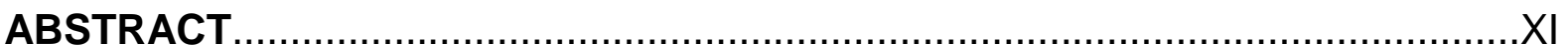

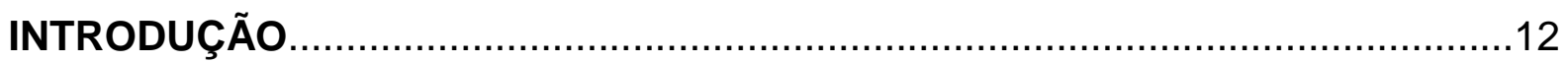

CAPÍTULO I - A CORRIDA DE RUA: ORIGEM E PERFIL DOS

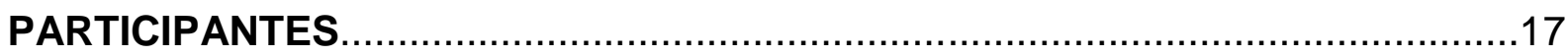

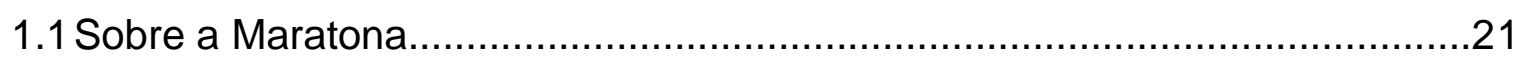

1.2 As primeiras Corridas de Rua no Brasil e em Brasília: breve exposição........23

1.3Buenos Aires: a segunda Maratona........................................................24

1.40 perfil dos corredores de rua........................................................... 34

CAPÍTULO II. "VOU COMPLETAR, MESMO QUE SEJA UM

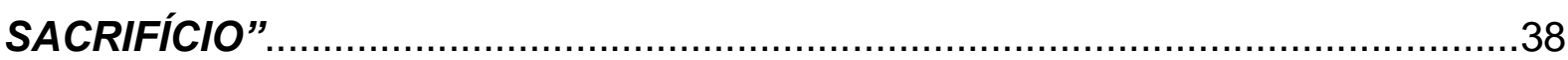

2.1Os Sacrifícios na Educação Física: sobre o que dizem as publicações nas

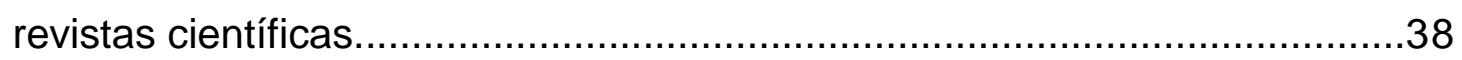

2.2 Sobre o Sacrifício.............................................................................. 48

2.3 Contextualizando o tema Sacrifício nas Corridas de Rua............................50

CAPÍTULO III. APROXIMANDO O TEMA RITUAL COM A EDUCAÇÃO FÍSICA E A

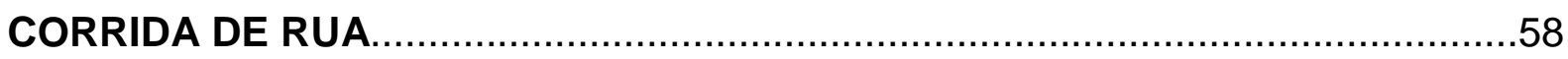

3.1 "E assim eu corro mais" (fala de um atleta amador, 2015)............................58

3.2 Sobre os ritos constituindo o ritual da Corrida de Rua..................................63

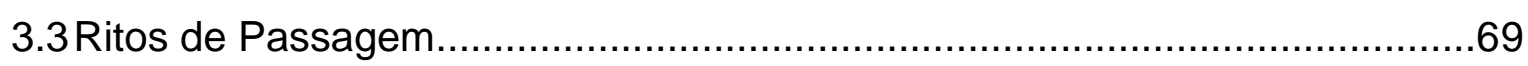

CONSIDERAÇÕES FINAIS: APROXIMANDO-SE DA LINHA DE

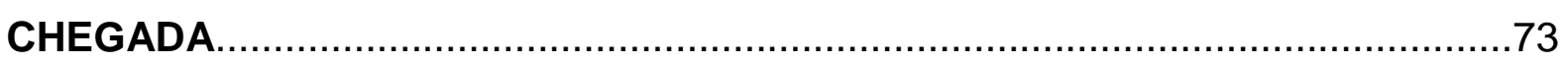

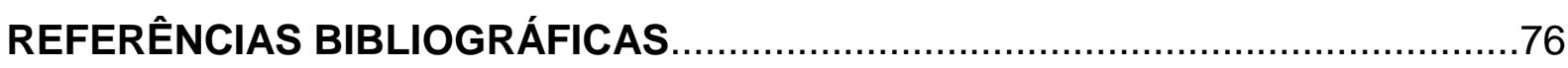

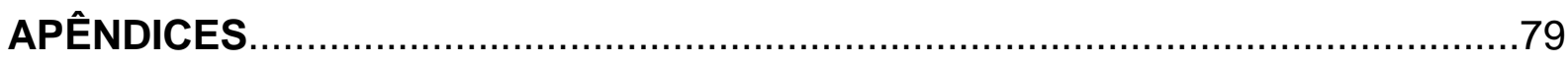

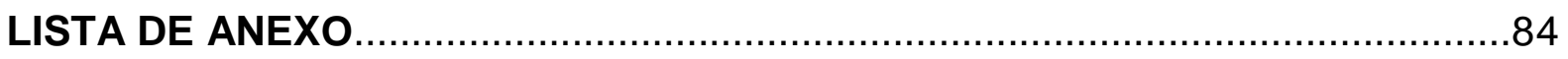




\section{LISTA DE FOTOS}

FOTO 01 - Maratona de Buenos Aires (B.A.) 2014 - Retirada dos kit's .26

FOTO 02 - Maratona (B.A.) 2014 - Momentos antes da largada (aquecer e alongar) 28

FOTO 03 - Maratona (B.A.) 2014 - Ênfase na marcação do quilômetro. .29

FOTO 04 - Maratona (B.A.) 2014 - Registro de amigos durante o percurso. .30

FOTO 05 - Maratona (B.A.) 2014 - A chegada. .32

FOTO 06 - Maratona (B.A.) 2014 - Comemoração pós Maratona. .33

FOTO 07 - Corrida de Reis 2016 - Largada para os 6km. 35

FOTO 08 - Sobre o perfil de alguns atletas. .36

FOTO 09 - Volta da Pampulha 2015 - Atleta correndo com pés descalços. .60

FOTO 10 - Volta da Pampulha 2015 - 'Carmen Miranda'. 61

FOTO 11 - Volta da Pampulha 2015 - 'Batman'. 61

FOTO 12 - Volta da Pampulha 2015 - Um índio e o 'Papai Noel' 62

FOTO 13 - Corrida de Reis 2016 - Corredores aquecendo. .66

FOTO 14 - Corrida de Reis 2016 - Largada para os 10km .68

FOTO 15 - Corrida de Reis 2016 - Entrega das medalhas 68 


\section{LISTA DE TABELA}

Tabela 1 - Lista de nomes fictícios dos entrevistados.. 14 


\section{RESUMO}

As corridas de rua consistem em fenômeno social contemporâneo de relevância (DALLARI, 2009; SILVA, 2009), sobretudo no contexto de Brasília. Em Brasília, cerca de 100 corridas são realizadas anualmente, tendo como participação um quantitativo próximo a dois mil corredores em cada evento (CFBAt, 2016). Além deste aspecto, motivações de ordem pessoal e profissional contribuíram para a escolha do tema de pesquisa. Aliada a esses fatores, também justificamos a importância do trabalho, em razão do baixo índice de publicações científicas voltadas para a temática. Diante do exposto, o problema de pesquisa configurou-se em saber: qual é o sentido/significado das corridas de rua para seus praticantes? A que perfil estes praticantes atendem? Tomou-se como objetivo geral: analisar a corrida de rua como um fenômeno social, considerando a relação que a aproxima do sacrifício corporal e de um sistema ritual para seus praticantes e, como objetivos específicos: (i) descrever o perfil (sexo, idade e fatores socioeconômicos) de um grupo de praticantes de corrida de rua de Brasília/DF; (ii) descrever e analisar a corrida de rua, com base nas experiências vivenciadas por um grupo de praticantes de Brasília/DF, considerando os ritos/o ritual e o sacrifício corporal. Do ponto de vista metodológico, a pesquisa se assenta em uma abordagem qualitativa, tendo como delineamento a pesquisa de campo e como técnica a observação participante. Além da observação participante, no qual o pesquisador também foi corredor, participando ativamente de algumas das corridas de rua, também julgamos importante realizar algumas entrevistas com um grupo de corredores de Brasília. Destacamos como conclusão principal que os sacrifícios fazem parte a todo o momento desta prática corporal, que consiste em um sistema de ritos, conformando um ritual. Desta forma, não apenas os treinos ou o investimento financeiro, as imposições mercadológicas que se projetam para os praticantes, mas também toda conexão existente entre a rotina de um corredor de rua e a busca pela superação de seus objetivos constituem o sentido, que consiste em nossa análise, no significado da corrida de rua, que aqui chamamos de ritual. Finalmente, a dor, o sofrimento, o desconforto físico e mental enfrentados em suas rotinas de corredores de rua, traduzidos para nós como os sacrifícios do corpo, não são um impedimento para seguirem em frente, quilômetro após quilômetro na conquista de seus objetivos, ultrapassar limites; superar sacrifícios.

Palavras-chave: Corrida de Rua, Sacrifício do Corpo, Ritual. 


\begin{abstract}
Road races consist of a relevant contemporary social phenomena (DALLARI, 2009; SILVA, 2009), especially in the context of Brasilia. In Brasilia alone, about 100 races are held annually, with the participation quantitative close to two thousand runners in each event (CFBAt, 2016). Furthermore, personal and professional motivations also contributed to the selection of this research theme. Coupled with these factors, the importance of this work is justified by the low rate of scientific publications focused on the topic. Given the above, the research problem is set up to know: what is the meaning/significance of road races to their practitioners? What profile do these practitioners meet? The general objective is then to analyze the road race as a social phenomenon, considering the relationship that approximates the races to a corporal sacrifice and a ritual system to their practitioners, as well the following specific objectives: (i) to describe the profile (sex, age and socioeconomic factors) of a group of street runners from Brasília / DF; (ii) to describe and analyze the road races based on the life experiences of a group of practitioners from Brasília-DF, considering the rites/ritual and body sacrifices. From a methodological point of view, the research is based on a qualitative approach outlined by field research and active observation as techinique. In addition to active observation, where the researcher was not only a runner but also actively participating in some road races, considerably as important was to conduct some interviews with a group of runners from Brasilia as well. We highlight as the main conclusion that sacrifices are part of every moment of this bodily practice, which consists of a system of rites that forms a ritual. Thus, it is not just the training and the financial investment, marketing impositions on road races practitioners, but also the entire connection between the routine of a road race runner and the search for overcoming goals that constitute our analysis, under the meaning of a road race, which here we call it a ritual. Finally, pain, suffering, physical and mental discomfort faced in the road race runner's routine, translated to us as the body sacrifices, are not an impediment to move on, kilometer after kilometer in order to achieve their goals, overcome limits; overcome sacrifices.
\end{abstract}

Keywords: Road Races, Body Sacrifice, Ritual. 


\section{INTRODUÇÃO}

No Brasil, ao longo de um período de 12 meses, ocorrem mais de 250 corridas de rua, situadas entre corridas de 5 ou 10 quilômetros; meia-maratona, corridas com $21 \mathrm{~km}$; maratonas, que contam com $42 \mathrm{~km}$, e, ultramaratonas, com mais de $42 \mathrm{~km}$, de acordo com a Confederação Brasileira de Atletismo (2016) ${ }^{1}$. Segundo informações do próprio site, as corridas de rua contam com aproximadamente 2 milhões de participantes, que são de diferentes sexos e faixaetária ${ }^{2}$, movimentando cerca de 3 bilhões de reais anualmente, com aumento progressivo de $7 \%$ ao ano desde $2009^{3}$. Esses dados ajudam a ilustrar a importância da corrida de rua como um fenômeno social contemporâneo. Portanto, ela pode ser considerada um prática corporal significativa entre os brasileiros, podendo-se tornarse passível de questionamento como: qual é o significado das corridas de rua?

Sendo assim, compreendemos a prática da corrida de rua como sendo uma atividade realizada por prazer ou lazer, que apesar de possuir um caráter competitivo, também revela traços de socialização (SILVA, 2009, p. 26). Notadamente, a dimensão que concebemos a corrida de rua acontece apenas consoante os limites estabelecidos pelo corpo do indivíduo praticante, isto é, até onde conseguimos superar nossos próprios limites, não estando muito preocupados com outros referencias. Por oportuno, em nosso entender, a dimensão da socialização durante a corrida de rua constitui-se em três etapas. $\mathrm{Na}$ etapa preparatória os corredores de rua amadores procuram realizar treinamento em equipe e buscam a motivação em grupo durante os treinos; durante a corrida, pois há durante o percurso pequenos comentários e estímulos tanto dos que estão participando da corrida, como do público que a assiste e, por fim, a etapa pós corrida, quando a socialização torna-se diversão e confraternização entre aqueles que, após 'sacrificarem' seus corpos durante o trajeto percorrido, buscam celebrar a conquista.

\footnotetext{
${ }_{1}^{1}$ Disponível em: http://www.cbat.org.br/regulamentos/default.asp (acessado em 14/02/2016);

2 Disponível em: http://negociosdoesporte.blogosfera.uol.com.br/2013/02/01/uma-nova-era-para-acorrida-de-rua-no-brasil/ (acessado em 20/06/2015);

${ }^{3}$ Disponível em: http://www.em.com.br/app/noticia/economia/2013/09/21/internas economia,451492/ atletas-de- circuito-de-rua-aquecem-mercado-que-movimenta-mais-de-r-3-bilhoes-ao-ano.shtm (acessado em 20/06/2015).
} 
Motivações de ordem pessoal e profissional, além da relevância que as corridas de rua apresentam como um fenômeno social contemporâneo (DALLARI, 2009) fazem parte da justificativa de escolha da corrida de rua como objeto desta pesquisa. Como praticante de corridas de rua desde os 16 anos, quando corri pela primeira vez os 5 quilômetros em Recife-PE, até os dias atuais já se foram mais de 20 anos praticando esta modalidade, passando a correr com maior frequência após ter vindo à Brasília, em 2006. Em 2008, passamos a atuar como professor licenciado e bacharel em Educação Física em uma assessoria esportiva de Brasília, que tem como foco as modalidades caminhada e corrida, ciclismo, natação e triatlo. O acompanhamento de alguns praticantes em uma assessoria esportiva de Brasília, a fim de iniciar um treinamento de corrida de rua ${ }^{4}$, foi importante para darmos mais relevância à prática corporal, o que também aguçou nossa curiosidade para a pesquisa. Aliada a esses dois aspectos, também justificamos a importância da realização desse trabalho, em razão do baixo índice de publicações científicas voltadas para a temática sobre a corrida de rua, compreendendo-a como um fenômeno de cunho social.

Para tanto, realizamos uma pesquisa de cunho exploratório em periódicos científicos da área da Educação Física brasileira e verificamos que no período de 10 anos, apenas 11 artigos trataram da temática. Deste modo, tais razões, isto é, a atuação profissional, o gosto pela corrida de rua e a curiosidade em entendê-la como um fenômeno social, foram os fatores que nos motivaram a desenvolver o trabalho aqui apresentado. Reconhecemos que, ainda que seja especialista na área de treinamento, a corrida de rua se apresenta como um fenômeno econômico e social de dimensões importantes e intrigantes.

Diante do exposto, visualizamos como um problema de nossa pesquisa entender: qual é o sentido/significado das corridas de rua para seus praticantes? A que perfil estes praticantes atendem? Nosso pressuposto é que a corrida de rua se constitui em um ritual, havendo em seu âmbito o sacrifício corporal.

Para tal nosso objetivo neste estudo passa a ser: analisar a corrida de rua como um fenômeno social, considerando a relação que a aproxima do sacrifício

\footnotetext{
${ }^{4} \mathrm{O}$ treinamento para corrida de rua é diferenciado do treinamento convencional em academias, pois existem vários aspectos relacionados à respiração, postura, lidar com a intensidade adequada a fim de evitar o cansaço físico; adequação do rítmo de corrida, entre outros aspectos.
} 
corporal e de um sistema ritual para seus praticantes. Temos como objetivos específicos:

(i)

Descrever o perfil (sexo, idade e fatores socioeconômicos) de um grupo de praticantes de corrida de rua de Brasília/DF;

(ii) Descrever e analisar a corrida de rua, com base nas experiências vivenciadas por um grupo de praticantes de Brasília/DF, considerando os ritos/o ritual e o sacrifício corporal.

Do ponto de vista metodológico, a pesquisa se assenta em uma abordagem qualitativa, tendo como delineamento a pesquisa de campo e como técnica a observação participante. Além da observação participante, o pesquisador também foi corredor, participando ativamente de algumas das corridas de rua, também julgamos importante realizar algumas entrevistas com um grupo de corredores de Brasília. Baseado em Fonseca (2002), nossa Pesquisa de Campo "caracteriza as investigações em que além da pesquisa bibliográfica e/ou documental, se coletam dados junto de pessoas, utilizando diversos tipos de pesquisa" (FONSECA, 2002, p. 32). E quanto à observação participante, para Flick (2009), ela acontecerá quando "o pesquisador mergulhar de cabeça no campo, que observará a partir de uma perspectiva de membro, mas deverá, também, influenciar o que é observado graças a sua participação" (FLICK, 2009, p. 207).

A tabela 1 compreende os nomes fictícios ${ }^{5}$, o mês de realização das entrevistas, o sexo e a duração aproximada em minutos.

Tabela 1 - Entrevista com os corredores

\begin{tabular}{|c|c|c|c|}
\hline Entrevistados(as) & Mês / Ano & Sexo & Duração (min.) \\
\hline Maurine & Abril / 2016 & Fem. & 47 \\
\hline Paulo & Abril / 2016 & Masc. & 37 \\
\hline Jackeline & Abril / 2016 & Fem. & 39 \\
\hline Sueli & Abril / 2016 & Fem. & 21 \\
\hline Luis & Maio / 2016 & Masc. & 38 \\
\hline Daniel & Maio / 2016 & Masc. & 30 \\
\hline
\end{tabular}

Fonte: ARRUDA (2016), com base em informações de campo.

\footnotetext{
${ }^{5}$ Todos os nomes aqui citados serão fictícios, atendendo-se ao que se propôs como critério junto ao Comitê de Ética em Pesquisa.
} 
As pesquisas de natureza qualitativa nos pareceram mais adequadas para a consecução dos objetivos propostos, tendo em vista que "a pesquisa está cada vez mais obrigada a utilizar-se de estratégias indutivas. Em vez de partir de teorias e testá-las, são necessários 'conceitos sensibilizantes' para a abordagem dos contextos sociais a serem estudados" (FLICK, 2009, p. 21). Assim, por meio de uma abordagem qualitativa, realizamos uma pesquisa de campo revestida de entrevistas com roteiro semiestruturado, realizadas com 6 (seis) corredores que se reconhecem amadores (não profissionais e que amam a corrida de rua). Julgamos importante a maturidade nesse reconhecimento como corredor amador, não apenas por não serem profissionais, mas por praticarem esta prática corporal por mais de 5 (cinco) anos. Realizamos a entrevista com igualdade numérica, tendo os pesquisados entre 38 e 57 anos.

Durante as corridas, como anteriormente mencionado, realizamos a observação participante, tentando imergir no universo pesquisado e buscar o sentido/significado das corridas de rua para seus praticantes. Com vista a isto, utilizamos, quando possível, anotações em 'diário de campo', fotografias e filmagens, a fim de termos a melhor compreensão do fenômeno estudado. Como escreveu De Oliveira, "o diário de campo foi construído para ser o lugar de registro dos movimentos, das leituras, dos tempos, espaços e das observações que ocorrem/ocorreram" (DE OLIVEIRA, 2004, p. 71).

Os corredores de rua $^{6}$, neste trabalho, são os principais agentes das corridas de rua. Quando nos referimos aos corredores de rua ou corredores amadores, nos referimos àqueles que praticam a corrida de rua, em espaços abertos, por cerca de três vezes por semana e que também participam ou eventualmente procuram participar de competições (as corridas de rua competitivas).

Dito isto, descreveremos brevemente como os capítulos desta dissertação foram construídos. Em nosso primeiro capítulo, trataremos de esclarecer em pequenos passos como surgiu a Maratona na história das corridas de rua, como esse surgimento influenciou no aparecimento das primeiras corridas de rua, como competição, e qual é o perfil dos participantes de corridas de rua, sobretudo considerando o contexto de Brasília/DF. Abordaremos ainda, com brevidade, sobre

\footnotetext{
${ }^{6}$ Neste trabalho não trataremos daqueles corredores que praticam esta prática corporal apenas na esteira (em sua residência ou nas academias) ou ainda aqueles que praticam a corrida de rua apenas em pistas de atletismos. Estes dois grupos também são praticantes da corrida, mas não da corrida de rua, objeto deste trabalho.
} 
a história das corridas de rua no Brasil e algumas das principais corridas, como a Corrida de São Silvestre (São Paulo/SP) e a Volta Internacional da Pampulha (Belo Horizonte/MG). Em seguida alguns registros sobre as corridas de rua no Distrito Federal e em Brasília até os dias atuais e uma descrição da nossa segunda Maratona, realizada em Buenos Aires.

No segundo capítulo, o foco estará na temática do Sacrifício, importante conceito da Antropologia, que nos ajudará a compreender como as corridas de rua constituem uma mescla entre prazer, realização e sacrifício corporal, com fundamento nas entrevistas realizadas.

Como parte integrante do tema teste trabalho, a palavra Sacrifício tratará de ser entendida como o sofrimento do corpo dos atletas amadores ao correrem por além de seus limites no intuito de concluir uma determinada corrida. No entanto, por diversas vezes, nas entrevistas, bem como no cotidiano das corridas e em conversas informais, a palavra Sacrifício é bastante recorrente entre os que correm, sendo assim uma categoria de grande representação neste trabalho.

Em seguida, no terceiro capítulo, a ênfase será nos rituais das corridas de rua (a partir da Educação Física), nos rituais com o olhar das ciências sociais e ainda como tratam os corredores entrevistados sobre este assunto, em seu cotidiano, nas corridas. Em seguida, traremos algumas das conclusões advindas deste trabalho. 


\title{
CAPÍTULO I - A CORRIDA DE RUA: ORIGEM E PERFIL DOS PARTICIPANTES
}

\begin{abstract}
"O que você está pesquisando é a história da rotina de todos nós que corremos, pois a dor que sentimos com esse esporte é quase permanente e nada melhor do que algumas rotinas (referindo-se aos rituais) para poder superar e seguir em frente" (atleta amador, que correu a Volta do Lago/Brasília-DF em maio de 2016 pela primeira vez).
\end{abstract}

Pouco antes de escrever algumas destas linhas, conversando com amigos após uma corrida de 100 quilômetros, um deles expressou em palavras o que está mencionado nesta epígrafe.

Correr passou a ser uma paixão, como atleta amador e treinador, assumindo nesta prática corporal da corrida de rua a natureza lúdica da prática esportiva ou do jogo interpretado extensivamente conforme o entendimento de Huizinga (2014, p. 11), para quem o jogo é uma atividade ou ocupação voluntária e livre, exercida dentro de certos e determinados limites de tempo e espaço, que atende às regras que são consentidas e obrigatórias e que possuem um fim em si mesmo. Essa aproximação da corrida com o conceito de jogo parece interessante à medida que, assim como a corrida, o jogo faz parte da cultura humana, consistindo numa prática social que foge a práticas ordinárias, isto é, ultrapassa a esfera daquilo que ocorre cotidianamente. Por outro lado, a associação corrida e jogo podem ser controversas, pois a corrida, sobretudo pela forma como a concebemos, é uma prática de natureza humana, enquanto o conceito de jogo para Huizinga (2014, p. 06) aparece como algo elástico, pois é uma prática que pode ser realizada por todos os animais.

Diversos autores afirmam que o homem nasceu para correr, pois "nossos ancestrais tinham de andar e correr para sobreviver" (GALLOWAY, 2009, p. 7). Os seres humanos se constituem por uma espécie corredora, pois quando crianças, logo após aprendermos a andar, isto é, logo após os primeiros passos, já começamos a correr. Silva em seu livro Run \& Fun, registrou que "podemos dizer que a corrida acompanha a evolução do homem, desde a transição do macaco para bípede, até os tempos atuais, quando correr já não é só mais um esporte, mas sim um estilo de vida" (SILVA, 2009, p. 14). 
Sendo assim, compartilhando das formulações comuns aos autores, pois a corrida é parte de nosso processo evolutivo do ponto de vista fisiológico, mas podese dizer que ela também é parte de nossa cultura.

Mauss, em sua obra intitulada Sociologia e Antropologia, trata também da corrida como uma técnica corporal a partir do "estudo de uma exposição, de uma descrição pura e simples das técnicas corporais". Ele descreve a corrida e suas diversas técnicas utilizadas em sua execução a partir da "posição do pé, posição do braço, respiração, magia da corrida, resistência..." (MAUSS, 2003, p. 227). Numa passagem ainda mais específica sobre as técnicas corporais particularmente pensadas para a corrida, ele diz:

“... ensinou-me a correr com os punhos junto ao corpo: movimento completamente contraditório a todos os movimentos da corrida; foi necessário que eu visse os corredores profissionais de 1890 para compreender que era preciso correr de outra maneira" (MAUSS, 2003, p. 214).

Essa compreensão apresentada por Marcel Mauss (2003) acerca da corrida, mostrando-nos a singularidade cultural da técnica corporal, coaduna-se com a interpretação apresentada por Marta Dallari, que em sua tese de doutorado, defendida em 2009, afirma, entre outras coisas, que "a corrida de rua é um fenômeno sóciocultural contemporâneo" (DALLARI, 2009, p. 16).

Em particular, esse é o aspecto das corridas que nos interessa, isto é, como aliar as corridas de rua, como um fenômeno sociocultural contemporâneo, com aspectos do bem-estar pessoal, como a sensação de prazer trazida pela corrida, por diferentes fatores de ordem fisiológica; como o estímulo produzido pelo nível de endorfina no cérebro até a possiblidade de se emocionar, como ocorreu na Maratona em Buenos Aires/AR ${ }^{7}$, passando pelos novos processos de socialização e seus rituais, que a corrida de rua enseja.

Galloway (2009) advoga que as corridas realizadas cerca de três vezes por semana proporcionam aos praticantes sensações de bem-estar, ao ponto de fazerem com que os corredores não parassem após iniciarem essa atividade. Com base nessa afirmação, ele procura caracterizar os tipos de praticantes de corrida, dividindo em cinco estágios de 'evolução' dos corredores em: o iniciante, o jogger, o

\footnotetext{
${ }^{7}$ Descreveremos mais à frente as sensações da Maratona de Buenos Aires/Argentina
} 
competidor, o atleta e, por último, o corredor. Segundo ele, "o corredor equilibra os elementos de condicionamento, competição, treinamento e vida social, e mistura a corrida com o resto da vida... O corredor é uma pessoa contente" (GALLOWAY, 2009, p. 23).

Brown e Henderson, por seu turno, afirmam que: "O corpo lhe dirá quais esforços consegue e quais não consegue realizar se você o escutar... o problema é que muitas pessoas ativas não querem parar para escutar ou não sabem como responder" (BROWN e HENDERSON, 2006, p. 36). Afirmações como estas corroboram com o 'aspecto humano' da corrida e do exercício. Não são apenas condições objetivas (tempo ou distância) e fisiológicas que fazem da prática da corrida uma rotina mais saudável, é preciso estar atento a diversos sinais, que não se resumem apenas ao batimento cardíaco ou à velocidade, vão mais além.

Pierce, Murr e Moss também dão atenção aos sinais subjetivos do corpo, defendendo que o corpo durante a corrida passa por processos adaptativos e que estão associados a novos fatores de estresse. Desse modo, é preciso estar atento ao que diz o corpo (PIERCE, MURR e MOSS, 2009, p. 152).

Silva (2009) cita o famoso Kenneth Cooper, um médico estadunidense conhecido em todo mundo por desenvolver o método Cooper de treinamento, cujo método foi tão amplamente difundido que, inclusive no Brasil, a palavra cooper é sinônimo de correr. "Cooper levou muitos americanos aos parques e a participar de corridas de rua, antes restritas a atletas de alta performance" (SILVA, 2009, p. 16). 0 mesmo autor afirma ainda, sobre a corrida e suas consequências para a saúde: "à ação desses três campos (saúde física, saúde emocional/cognitiva e saúde social) chamamos de tríade da vida saudável" (SILVA, 2009, p. 18). Mais especificamente sobre a 'saúde social' o autor aprofunda: "correr pode ser um ato solitário, mas cada vez mais cresce a corrida em grupos. E esse crescimento se deve, sobretudo, à necessidade que temos de pertencer a um grupo" (SILVA, 2009, p. 24).

Uma das entrevistas realizadas para compor este trabalho, com um corredor de rua, do sexo masculino, com idade de 47 anos:

"E a corrida te possibilita ter um convívio, quebrar um pouco aquela rotina do trabalho, das relações que você tem no trabalho. E, para mim, eu acabei tendo um círculo novo de amizades, de pessoas de diferentes origens que me ajudam a aliviar um pouco as tensões do trabalho e também a distância que eu tenho... que eu fico a maior 
parte da minha família... E uma outra motivação foi isso, que eu precisava ocupar o tempo [...] então meus filhos ficam fora, minha esposa fica fora, mora em outra cidade e isso também me ajudou a ocupar o tempo e relaxar um pouco a mente, desligar um pouco porque não adianta também você ficar curtindo a saudade o tempo inteiro; a missão da vida aí é o trabalho e é um meio, mas a gente tem que administrar bem essa parte do corpo, para que a mente fique equilibrada. Então o esporte e a corrida me dá equilíbrio, me atenua e os problemas se tornam mais simples" (Daniel).

Como se percebe, a corrida segundo o entrevistado possibilita o convívio, a descotidianização, ruptura da rotina e a constituição de um ciclo de amizades, o que pode nos possibilitar a compreensão do sentido de tribo, conforme Maffesoli (2004). É um sentimento comum, entre as pessoas, o desejo pelo pertencimento a uma 'tribo' e quanto aos corredores, isso não é diferente. Assim como discorrido na experiência relatada no subtítulo Desafiando a segunda Maratona (no capítulo 1 deste trabalho), há uma importância dada ao coletivo, ao grupo de amigos que se aproximam por um fim comum: a corrida.

Maffesoli em "El tempo de las tribos" foi muito feliz ao descrever a empatia que faz com que os grupos se encontrem para um fim comum:

"Frente a la anemia existencial suscitada por un social demasiado racionalizado, las tribus urbanas destacan la urgencia de una socialidad empática: compartir emociones, compartir afectos. Lo recuerdo, el "comercio", fundamento de todo estar-juntos, no es, simplemente, intercambio de bienes; es también "comercio de ideas", "comercio amoroso" (MAFFESOLI, 2004, p.20).

Tribos estas que, em dias de modernizações tecnológicas, demonstram um 'traço' de retorno à outros tempos, se encontrar, neste caso com o fim de se exercitar, correr, partilhar emoções comuns a este público, torna-se um gesto de maior importância quando ele diz:

"La expresión es juiciosa y caracteriza pertinentemente el imaginario de esta competencia deportiva con toda su carga, manera más o menos barroca, de fantasías, de sueños, de alegría de estar juntos y de ludismo compartido. Pero tal "regreso" puede ser aplicado a las 
muchedumbres contemporáneas. Éstas no son más que uma sucesión de tribus que expresan de todo corazón el placer de la horizontalidad, el sentimiento de la fraternidad, la nostalgia de una fusión preindividual" (MAFFESOLI, 2004, p. 19).

A experiência vivenciada na rotina (bem como no ritual do corredor de rua) ou na prática da corrida de rua costuma mesmo ser um misto entre competição e lazer. Não é tão simples separar esses sentimentos ao passo que competir (seja consigo ou com os outros) e se divertir, numa condição de esporte e exercício, se fazem presentes. Muitas vezes e muito comumente, entre os corredores de rua, formar duplas ou até pequenos grupos a fim de correrem num mesmo ritmo, num sentimento de cooperação e ajuda mútua, torna a corrida um momento ainda mais instigante, pois além do 'desafio' de completar certa distância, ainda busca-se isto ao lado de pessoas amigas, com o mesmo intuito, de superarem suas expectativas (de tempo, ritmo ou distância), juntos. Como vivemos em sociedade, ao escolhermos determinados lugares para frequentar, estamos comunicando preferências, status, opções (PEIRANO, 2003, p. 04).

\subsection{Sobre a Maratona}

Neste trabalho decidimos por fazer um pequeno 'passeio' para contar sobre a corrida que, entre os corredores de rua, vem a ser o maior dos desafios a serem superados: a maratona. A distância oficial, atualmente, é de 42.195 metros, no entanto muitos anos se passaram até chegarmos até esta marca oficial.

Participar de uma corrida de rua como competição pode assumir variados sentidos. É necessário esclarecer que o recorde da maratona é pouco mais que duas horas, no entanto, praticamente todas as maratonas, em todo mundo, dispõem aos seus competidores um tempo total de seis horas para conclusão de todo percurso. Ou seja, competir passa a ter um sentido muito amplo, não sendo apenas competir com os demais corredores. Pode-se competir com seu próprio tempo ou competir buscando percursos ainda maiores.

A história da maratona foi contada em muitas versões, por pesquisadores de diferentes áreas. $O$ intuito desta pesquisa inicial não é aprofundar-se em como 
surgiu a maratona, mas verificamos alguns trabalhos publicados que julgamos importantes a fim de destacar alguns destes 'contos'. Por muitos anos acreditamos apenas na 'lenda' dos cerca de 40 quilômetros percorridos por um soldado ateniense para anunciar que a vitória foi alcançada na batalha entre gregos e persas, no ano 490 a.C.

Sobre a guerra há poucas dúvidas que realmente ocorreu, mas que o soldado Filípides ${ }^{8}$ foi o único responsável por levar a notícia da vitória, algo a mais há que se contar. Segundo Rodrigues ${ }^{9}$, após algumas vitórias dos persas sobre os gregos (entre 490 e 479 a.C.), estrategistas atenienses incumbiram um homem de nome Filípides de fazer contato com os Lacedemónios ${ }^{10}$ e se unirem aos atenienses, contra os persas, na grande batalha na Península de Maratona. A distância percorrida por Filípides foi de aproximadamente 220 quilômetros e isso houvera ocorrido em apenas um dia (RODRIGUES, 2010, p. 42).

Só após a vitória dos gregos sobre os persas (conhecida como o fim da guerra Médica) é que todos os soldados que restaram da guerra, vitoriosos, teriam então percorrido os cerca de 40 (quarenta) quilômetros; distância que houvera entre o local da batalha (Península de Maratona) e a cidade de Atenas.

Daí por diante sabemos que entre os aproximados 40 quilômetros iniciais e os atuais 42.195 metros oficiais, alguns fatos verdadeiros ocorreram e o principal deles é que nos Jogos Olímpicos de 1908, em Londres, com o intuito de fazer com que a linha de chegada passasse em frente ao camarote real, no Estádio Olímpico de White City, onde estaria a rainha Alexandra, da Inglaterra, a distância passou a ser acrescida de 2.195 metros (MATTHIESEN, 2012, p. 465).

Após o ocorrido, em 490 a.C. e a primeira maratona oficial, se passaram cerca de 2.500 anos e esta aconteceu nos Primeiros Jogos Olímpicos Modernos, em 1896, na cidade de Atenas, uma homenagem ao soldado Filípides, a pedido do francês Michel Bréal, para ter a maratona inclusa nos Jogos Olímpicos (DALLARI, 2009, p. 25). Assim, entre 1896 (I Jogos Olímpicos Modernos) e 1904 a maratona teve sua distância percorrida em 40 quilômetros.

\footnotetext{
${ }^{8}$ Alguns autores também se referem a este soldado como de nome: Phidippides, Pheidippides, Thersippos e também Euklis;

${ }^{9}$ Nuno Simões Rodrigues: doutor em história pela Universidade de Lisboa;

${ }^{10}$ Os Lacedemónios ou Lacedemônia era uma unidade regional da Grécia. Sua capital é a cidade histórica de Esparta.
} 


\subsection{As primeiras corridas de rua no Brasil e em Brasília: breve}

exposição

Julgamos ainda fundamental para este trabalho o resgate histórico dos primeiros registros das corridas de rua no Brasil e em nossa cidade. Brasília tem sido, no cenário nacional, a segunda cidade com maior número de corridas de rua, ficando atrás apenas da capital São Paulo.

As corridas de rua se enquadram no conjunto de provas que formam a modalidade do atletismo, e por sua vez é regulamentada e regida pelas instituições representantes deste esporte, que no Brasil fica a cargo da Confederação Brasileira de Atletismo - CBAt e internacionalmente pela Associação Internacional de Federações de Atletismo - IAAF (ROJO, 2014, p. 2).

Por muitos anos, na adolescência, acompanhamos em família, a transmissão da corrida de São Silvestre. Acontece sempre no último dia do ano e sua largada ocorria por volta das 17h. Apenas na atualidade descobrimos a importância desta corrida, sendo ela uma das mais antigas corridas de rua no Brasil. Em 2024 ela completará 100 anos de história, sendo sua primeira edição datada de 1925. A Corrida de São Silvestre sempre foi, no Brasil, a corrida com a maior participação de inscritos para percorrer os 15 quilômetros de extensão.

Como escrito por Dallari, a primeira edição da São Silvestre teve largada às 23h40' e apenas 60 atletas largaram (DALLARI, 2009, p. 26). Segundo o regulamento oficial da corrida de São Silvestre, em 2015 o número de vagas disponível para inscrição foi de 30.000 (trinta mil) atletas. A corrida de São Silvestre é, dentre centenas de corridas tradicionais no Brasil, uma das mais desejadas entre os corredores de rua. Atualmente a corrida continua sendo realizada no último dia de cada ano, porém desde 2012 passou a largar às 9h da manhã, oportunizando assim a participação de atletas em maior quantidade.

Em Brasília, o primeiro registro da Maratona, data de 1984, vinte e quatro anos após a inauguração desta cidade (Anexos II e III). Infelizmente não foi possível dar continuidade ao legado da Maratona pois ao longo de quase 10 (dez) anos de atuação neste contexto, percebe-se que por diversos motivos, como questões políticas, falta de patrocínio e falta de interesse por parte dos que promovem eventos esportivos, público e/ou privado, não temos uma Maratona com calendário 
definido anualmente. Em conversas informais, ao longo desta pesquisa, me deparei com um atleta amador que afirmou ter participado de uma Maratona em 1983, porém não encontramos registros deste evento.

Sem dúvida, um acontecimento sobre o qual nos questionamos: porque uma corrida de tamanha importância, que é a Maratona, não tem seu registro com facilidade de acesso? Porque a falta de continuidade nas edições nos anos seguintes?

Diferentemente da história da Maratona, outras três tradicionais corridas permanecem no calendário anual de eventos dessa natureza e com amplo material de registros. A principal delas é a Corrida de Reis (acontece no mês de janeiro), que sempre foi realizada através do governo do Distrito Federal ${ }^{11}$. É, provavelmente, a corrida mais popular no calendário de corridas de rua, visto que não há cobrança no ato da inscrição. Este ano ocorreu a edição 46, sendo esta a corrida de rua mais antiga de Brasília, segundo os registros da Federação Brasiliense de Atletismo, bem como os registros do Correio Braziliense (Anexo I). Além da Corrida de Reis, em 2016 a Meia Maratona Internacional da Caixa ${ }^{12}$, única corrida de rua em Brasília com certificação internacional, sendo ela válida para o ranking mundial nesta distância (21.098 metros), completou 17 anos consecutivos. No passado esta corrida era oferecida apenas na distância completa, no entanto atualmente também são disputadas as distâncias de 5.000 e 10.000 metros. Por fim, acontece em Brasília há 13 anos a Volta da Caixa ${ }^{13}$, uma ultramaratona de 100 quilômetros percorrendo as vias mais próximas do lago Paranoá.

\subsection{Buenos Aires: a segunda maratona}

Em 10 de outubro de 2010, realizamos o 'desafio' de correr a primeira Maratona. Éramos um grupo de aproximadamente 25 pessoas (entre corredores, familiares e amigos), na cidade de Buenos Aires, Argentina. Passados quatro anos,

\footnotetext{
${ }_{11}^{11}$ Atualmente, a inscrição é gratuita e as vagas em 2016 foram de 8.000 (oito mil) inscrições;

${ }^{12}$ No Anexo VI (p. 90) contém as informações contidas no site da prova, acessado em 10 de maio de 2016, ano em que ocorreu a $17^{a}$ edição da corrida;

${ }^{13}$ No Anexo $\mathrm{V}$ encontraremos a divulgação da primeira edição desta corrida. A ultramaratona conta com cerca de 4.500 atletas que vão desde a categoria solo (com 100 ou 60 quilômetros), mas a principal participação dos atletas se dá pela categoria revezamento, podendo ser até de 8 (oito) atletas. A largada ocorre sempre às $6 \mathrm{~h}$ da manhã e a conclusão da categoria solo acontece com 12 horas, enquanto as equipes têm que concluir a corrida em até 10 horas.
} 
em 2014 passamos a nos preparar para uma nova maratona. Havia um grupo grande na assessoria interessado por uma maratona fora do Brasil e mais uma vez a cidade escolhida foi Buenos Aires. O percurso desta Maratona é, na maior parte do tempo plano, o que facilita para correr 42 quilômetros, visto que os esforços desprendidos com subidas e descidas, podem se tornar um fator complicador. A organização da prova é considerada satisfatória, pois oferece condições favoráveis durante todo o percurso, com hidratação e pessoal treinado e distribuídos ao longo de todo percurso; além disso, as avenidas largas e bem conservadas facilitam o deslocamento e condições climáticas no mês de outubro são bem favoráveis, pois acontece num período de temperaturas mais amenas.

Após dois anos de treinamento com o mesmo grupo de praticantes de corrida de rua, em 2010 passamos a acompanhar a preparação daqueles que fariam sua primeira Maratona, uma corrida de rua com $42 \mathrm{~km}$. Para alguns (sejam treinadores ou atletas amadores, que aqui chamaremos, por vezes, de praticantes de corrida de rua), completar uma maratona é o auge a ser alcançado nessa prática.

Como esportista e treinador não concordamos integralmente com a defesa dessa ideia, pois correr uma maratona é também algo excludente, visto que 42 quilômetros é uma distância bastante longa, trazendo, em diversos casos, desgastes físicos e também emocionais bastante severos ${ }^{14}$. No entanto, ao ser 'designado' a treinar alunos que se destinaram a completar, pela primeira vez, uma maratona, nos desafiamos também a treinar, junto com eles, por um desafio pessoal e também profissional, pois vivenciando tal prática, poderíamos também compreender melhor como definir a estratégia mais adequada a ser aplicada para cada um dos praticantes e, assim, levá-los, com alguma segurança, a completar sua primeira maratona.

\section{Os preparativos e a viagem}

Fizemos um planejamento de treinos coletivos aos domingos, a fim de aproximar o grupo, motivar durante o treino e até simular os treinos prevendo a prova, largando às 7h30'. Realizamos algumas reuniões para discutirmos

\footnotetext{
${ }^{14} \mathrm{Na}$ maioria dos casos uma preparação para uma Maratona dura cerca de 6 (seis) meses, somando aproximadamente mil quilômetros a serem percorridos neste período.
} 
estratégias, mostrar o percurso da prova e as atividades que faríamos coletivamente como lazer, durante nossa viagem à Buenos Aires ${ }^{15}$.

Estando às véspera da Maratona, viajamos em pequenos grupos e familiares e só no sábado, dia anterior à corrida, é que todos haviam chegado. A primeira agenda coletiva com todos em Buenos Aires foi na entrega dos kit's ${ }^{16}$, no local indicado pela organização para prova, um Centro de Eventos.

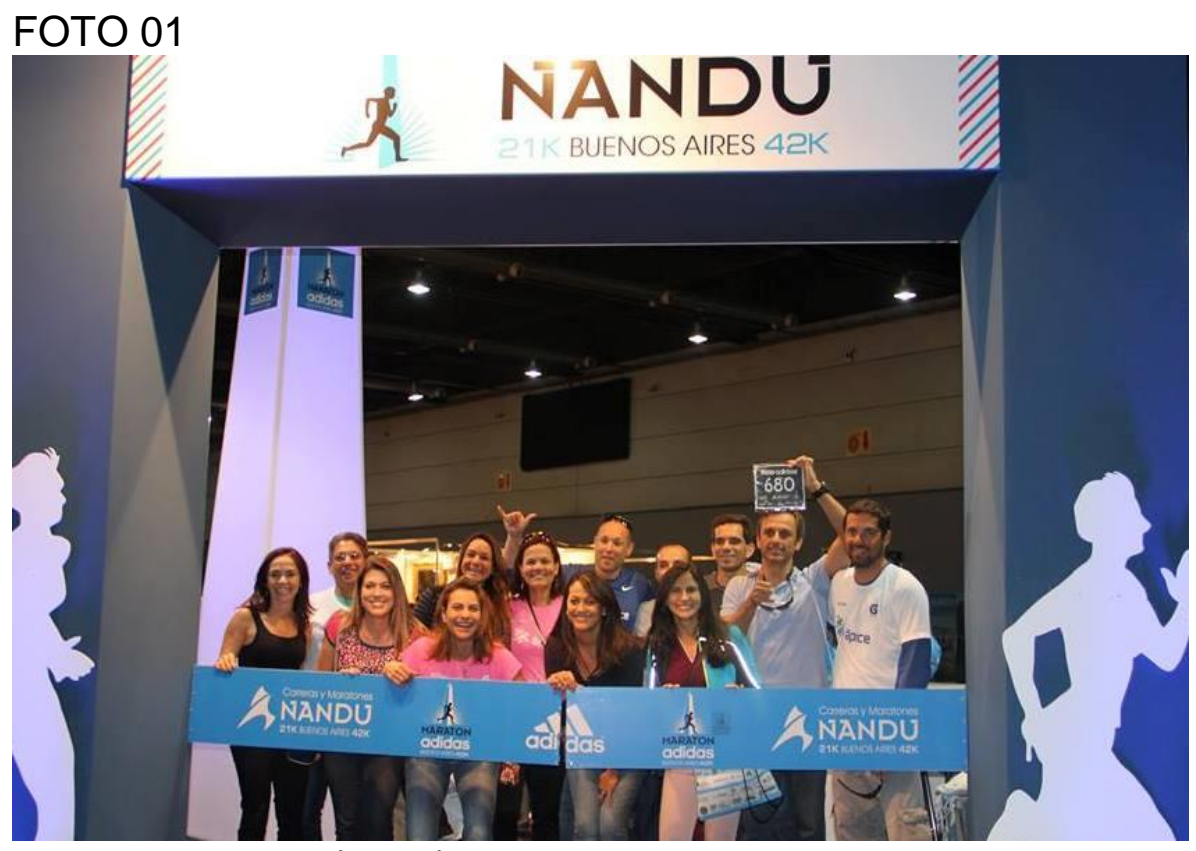

Fonte: ARRUDA (2014). Arquivo de pesquisa.

\section{Correndo 'sem controle'}

$\mathrm{Na}$ semana véspera da prova pude assistir uma entrevista com o maratonista Vanderlei Cordeiro de Lima (atleta brasileiro que foi empurrado por um torcedor para fora da corrida em plena maratona dos Jogos Olímpicos de Atenas em 2004). Na entrevista, o maratonista Vanderlei falava de sua estratégia para correr a prova. Houvera dito que correria sem nenhum controle de tempo (sem relógio), apenas se guiando, subjetivamente pela sensação de esforço durante a prova e tendo como referência de distância as placas postas a cada quilômetro durante o

\footnotetext{
${ }^{15}$ Ao longo dos meses de julho a outubro realizamos diversos treinos longos, juntos, quase todos no Lago Sul/Brasília - um local considerado seguro e com boas condições para treino nos finais de semana;

${ }^{16}$ Kit da corrida - em geral são compostos de uma pequena mochila com a camisa alusiva à prova, o número de peito, o ship de cronometragem e algum outro produto de patrocinadores - como boné ou alguma propaganda.
} 
percurso. Ele justificou que desta forma não ficaria tão preocupado em observar e controlar sua intensidade pelo relógio, a fim de minimizar a ansiedade.

Naquele instante passamos a acreditar na possibilidade de percorrer os 42 quilômetros sem ter o controle da intensidade através de um equipamento, mas apenas correr percebendo outros fatores de ordem subjetiva. Com uma câmera na mão, registramos alguns momentos particularmente importantes durante a prova. Ao longo das próximas linhas iremos incluir alguns comentários sobre as sensações desta experiência.

\section{O primeiro terço da corrida}

A largada da prova acontece às 7h30' (horário local). A previsão do tempo informara cerca de 12 graus no início do dia e aproximadamente 25 graus após às 10h. Levantamos por volta da $5 \mathrm{~h}$ para os preparativos iniciais, que diríamos ser um 'ritual' entre os atletas, seguindo passos fundamentais para a preparação do dia em função da prova, como necessidades fisiológicas matinais, amarração do tênis, conferência da fixação do chip de registro e o número de peito na camisa e finalmente tomar o café da manhã.

Encontramo-nos no 'hall' do hotel logo cedo para uma alimentação leve e em seguida saímos em pequenos grupos, com destino à largada ${ }^{17}$. Um pequeno imprevisto nos fez atrasar, pois poucos taxistas se dispuseram a aventurar-se até a largada, visto que ficara distante do hotel e muitas das ruas e avenidas estavam bloqueadas para a passagem dos Maratonistas.

Chegando ao local próximo à largada, caminhamos cerca de 20 minutos e fomos em direção ao local previamente marcado com os demais, em frente ao guarda-volumes. Nesta caminhada registramos alguns grupos se aquecendo, pessoas se despedindo e desejando uma boa prova a familiares e amigos. Julgamos de grande importância a energia advinda de pessoas próximas num instante anterior à largada de uma prova dessa importância. São gestos como estes que transmitem ao atleta a confiança, o incentivo e o reconhecimento pelo esforço da preparação.

\footnotetext{
${ }^{17}$ (havíamos marcado para nos encontrarmos, todos, em frente ao guarda-volumes por volta das $7 \mathrm{~h}$ no local da largada).
} 


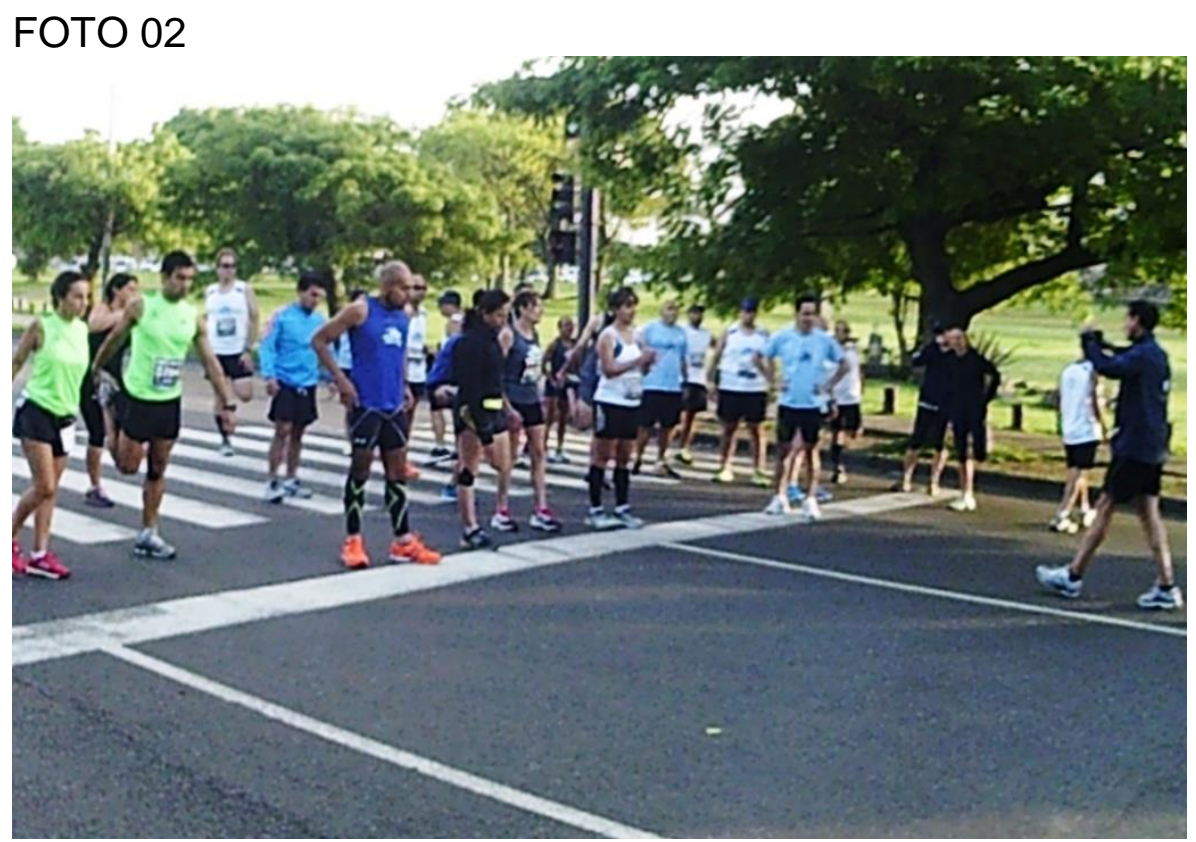

Fonte: ARRUDA (2014). Arquivo de pesquisa.

No instante da largada de uma maratona, uma 'explosão' de sensações que inclusive podem chegar a atrapalhar toda estratégia de prova, como a ansiedade de realizar a prova unicamente dentro de um plano traçado previamente, mas que por uma série de situações, podem não ajudar a manter a calma e o planejamento. Mudança de temperatura, dores, sinais de câimbras são circunstâncias que precisam ser consideradas. Descansar um pouco, caminhar, hidratar-se ou ingerir algum carboidrato, são algumas atitudes necessárias para não causar demasiada fadiga ao corredor.

A temperatura estava agradável (cerca de 15 graus), realizamos os procedimentos como entrega de sacolas no guarda-volumes, nos hidratamos e realizamos um breve aquecimento (numa grande área gramada, ao lado do corredor de largada, local onde centenas de outros atletas também se preparavam). Além de aquecer, esse é o momento de aplicar protetor solar, amarrar/verificar o cadarço no tênis, bem como fazer os ajustes finais nas vestimentas como meias, bonés e outros 'adereços'; são alguns dos registros visuais que percebemos em muitos dos atletas.

Particularmente, ajusto os cadarços do tênis de forma que eles não fiquem 'saltando' ao longo das passadas, deixo-os bem firmes e prendendo as pontas. Às vezes percebo que estou tão concentrado durante a prova que um 'estalo' da ponta do cadarço fazendo contato com o tênis pode atrapalhar a concentração, forçando a parar para um novo ajuste. O gesto de parar e agachar-se no meio de uma corrida 
exige alguns cuidados, para não causar um acidente, pois alguém pode esbarrar sem que perceba.

Chegada a hora de se posicionar, pontualmente às 7h30' foi dada a largada para os 42.195m. Novamente me emocionei na largada ao lembrar o meu pai (s. Paulino) que faleceu de um infarto em 7 de julho de 2013 ao voltar para sua casa após ter corrido $5 \mathrm{~km}$ numa corrida de rua. Sempre que iniciamos uma corrida, sua imagem e sentimento de saudade se fazem presentes. Fizemos alguns registros fotográficos na largada e ao longo dos primeiros $10 \mathrm{~km}$ (parte central de Buenos Aires), passando por diversos monumentos históricos da cidade, como o Obelisco e a Casa Rosada.

Ao longo do percurso diversas situações curiosas ocorreram, como no quilômetro 8, que encontramos com um de nossos alunos e corremos cerca de 1 quilômetro juntos, papeando e expressando palavras de incentivo. Por não estarmos correndo com algum relógio, naquela Maratona optamos por perceber as diversas sensações expressas pelo corpo, desta forma passamos a ouvir 'os sinais ao redor', a fim de nos sentirmos mais concentrados na prova - o carro que buzina, o grito de motivação do atleta, os aplausos proferidos daqueles que assistem a prova, seja na calçada ou ao longo das sacadas dos prédios históricos durante o percurso, nos faz sentir mais atentos, quilômetros afora.

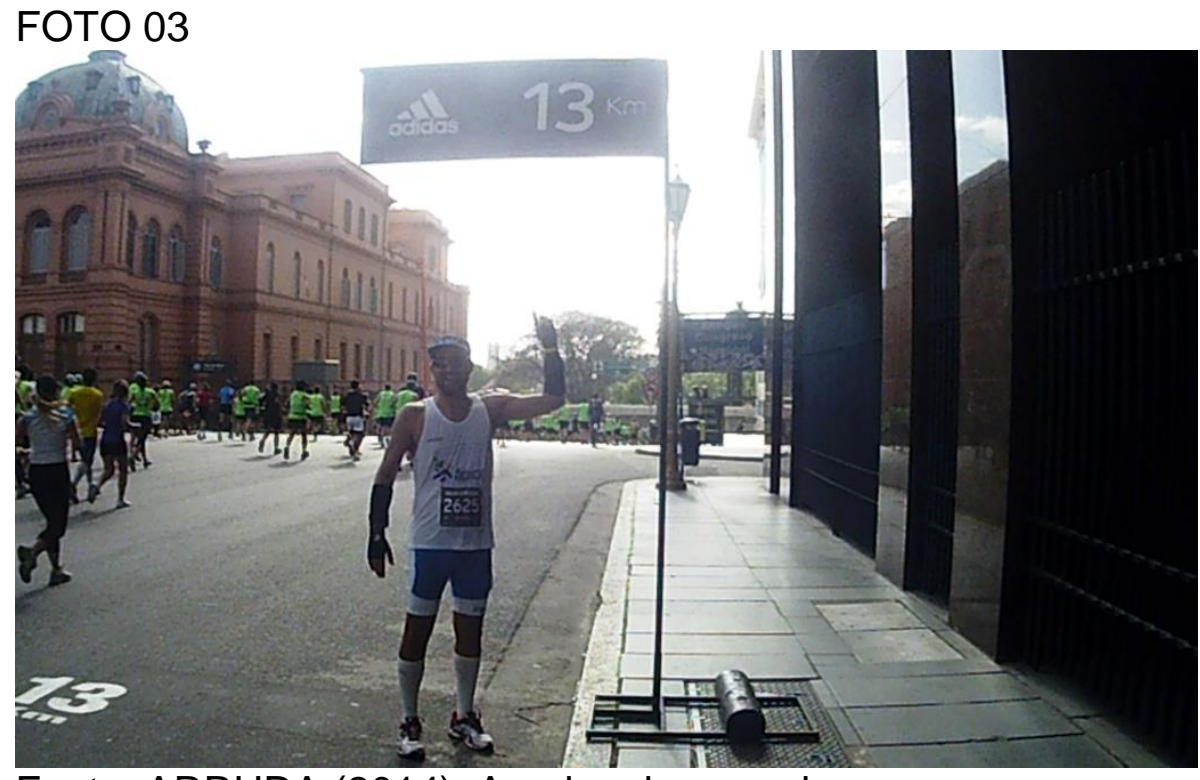

Fonte: ARRUDA (2014). Arquivo de pesquisa. 
E assim se passaram os primeiros 15 quilômetros da maratona, num ritmo tranquilo, sem ansiedades ou dores, como planejado.

Ao aproximar-se do quilômetro 16, no bairro de La Boca, onde encontra-se o imponente estádio conhecido como La Bombonera, do famoso time de futebol Boca Juniors, percebemos nas costas de uma atleta, que estava à nossa frente, um sinal de sangue e numa tentativa de comunicação em espanhol avisei-a, pois não sabia se ela havia percebido. Ela agradeceu, mas na euforia da corrida, não entendi o que ela havia falado. Um rapaz ao seu lado falou: - Obrigado! E foi então que percebmos que estávamos falando com brasileiros.

Num instante de descontração, todos riram e então entendi que estava acompanhada de mais três amigos. Conversamos um pouco, nos apresentamos. Eram da cidade de Vitória - ES. Fizemos uma breve amizade, seguimos juntos por alguns quilômetros sintonizados, pela energia e alegria que eles carregavam consigo e pelo ritmo.

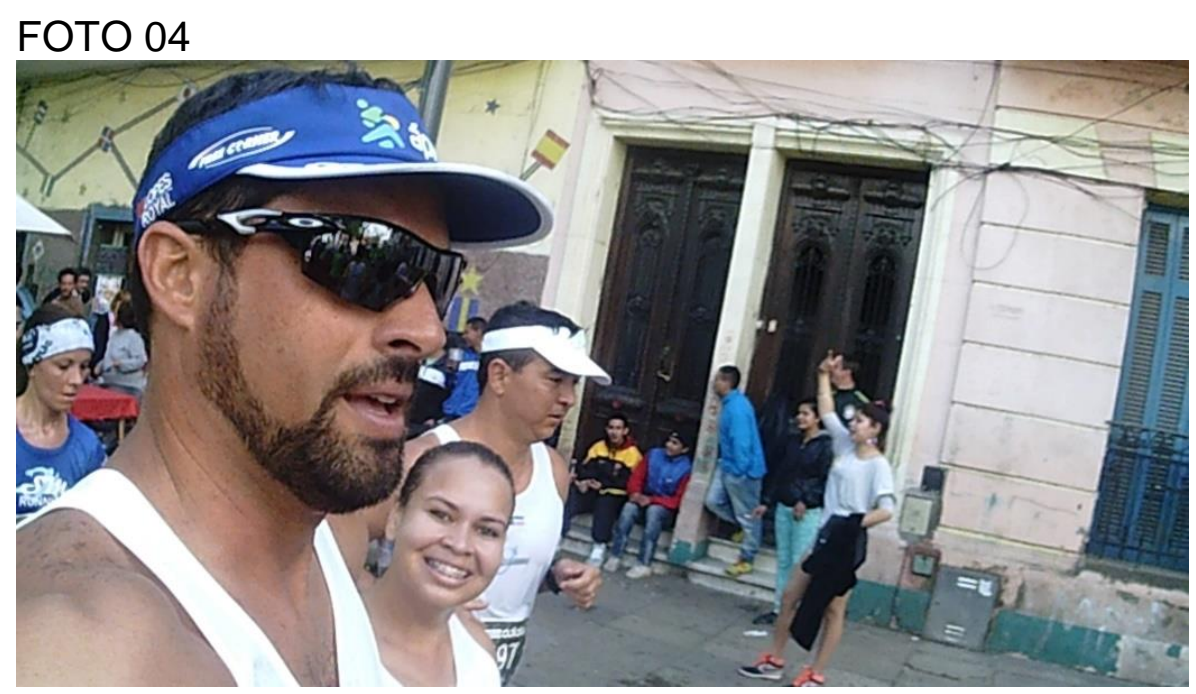

Fonte: ARRUDA (2014). Arquivo de pesquisa.

De forma empírica, e em grande parte dos relatos dos atletas, ao correr uma Maratona, entre o quilômetro 22 e 32 se percebem sinais de cansaço em muitos dos maratonistas. Esse intervalo de quilômetros costuma ser mais 'silencioso', pois já corremos bastante e, no entanto ainda faltam alguns quilômetros para se concluir. Dizem alguns colegas que é a fase em que passará com mais facilidade aquele que está mais concentrado, quem tem mais paciência ou aqueles que têm as motivações mais claras em mente. Podemos sugerir como um período de equilíbrio emocional. 
Já estávamos passando pelo quilômetro 32 e a essa altura já havíamos percorrido todo o bairro do Puerto Madero ${ }^{18}$, quando eles decidiram ir um pouco mais rápido, pois agora faltavam menos que 10 quilômetros. Como já havíamos corrido no mesmo percurso há 4 anos atrás, alertamos a eles que esta última parte da prova merecia uma atenção especial, pois além da temperatura mais elevada e o cansaço mais evidente, os próximos 6 quilômetros seriam percorridos numa região pouco atrativa à corrida, pois não haviam mudanças de paisagem, passaríamos por uma região portuária, descrevo: 'sem graça', com pouca sombra para se abrigar do sol. Só nos últimos 5 quilômetros é que a 'alegria houvera de voltar', pois estaríamos novamente próximos ao centro da cidade e do ponto de chegada (no bairro de Belgrano - mesmo local da largada).

Eles seguiram com o ritmo um pouco mais rápido e eu, então, seguimos com cautela, novamente "sozinho". Aqui vale ressaltar que desde o quilômetro 20 já estava sentindo algum desconforto muscular na perna esquerda e na lateral do joelho, também esquerdo. No caso do joelho, era uma dor que conhecemos como 'joelho de corredor'19. Desta forma, já estávamos correndo com uma pequena limitação na amplitude das passadas e por isto desencadeando a dor muscular. A possibilidade de desistir, por muitas vezes rodeava os pensamentos. Após o quilômetro 35 muitas pessoas já caminhavam por longos trechos, enquanto outros já estavam sentados pelas calçadas (se alongando ou por terem mesmo desistido). No quilômetro 36 havia uma tenda da Cruz Vermelha e a fila para atendimento era uma imagem desanimadora, pois cerca de 10 ou 12 pessoas esperavam para serem atendidas (com gelo, algum analgésico ou mesmo uma rápida massagem), o fato é que faltando 10 quilômetros para a chegada, esses poucos quilômetros 'parecem não ter fim'.

Particularmente, costumamos adotar uma estratégia ao correr percursos mais longos, no intuito de maior preservação visando a etapa final e que tem dado certo. Preferimos dividir uma corrida em 2 (duas) partes, procurando realizar a primeira metade da corrida com uma intensidade mais leve que a metade final. Visto

\footnotetext{
${ }^{18}$ Puerto Madero é um centro comercial e gastronômico moderno, que se diferencia do centro de Buenos Aires, pois seus prédios são bastante altos e com conceitos modernos de arquitetura.

${ }_{19}$ Joelho de corredor é uma expressão que diz respeito a diversas condições associadas à dor ao redor da parte anterior do joelho. Essa dor muitas vezes é consequência de um desalinhamento que provoca irritação no lado inferior da patela.
} 
que ao longo da corrida a temperatura tende a aumentar e o cansaço também, manter as reservas energéticas preservadas para o final tende a ser mais positivo.

Desta forma, naquela maratona, os últimos três quilômetros foram os mais rápidos, sendo o último quilômetro ainda melhor. Ao passar pelo quilômetro 40 uma atleta ultrapassou num ritmo que nos deixou bastante surpreso "uma pessoa, naquela altura da prova, conseguir correr tão rápido", então buscamos ânimo e motivação para segui-la até quando pudesse (e deu certo), pois seguimos acompanhando-a até a entrada do corredor final ${ }^{20}$. Foi então que, para nossa surpresa, estava ao lado dos amigos do Espírito Santo. Nos abraçamos e cruzamos a linha de chegada juntos.

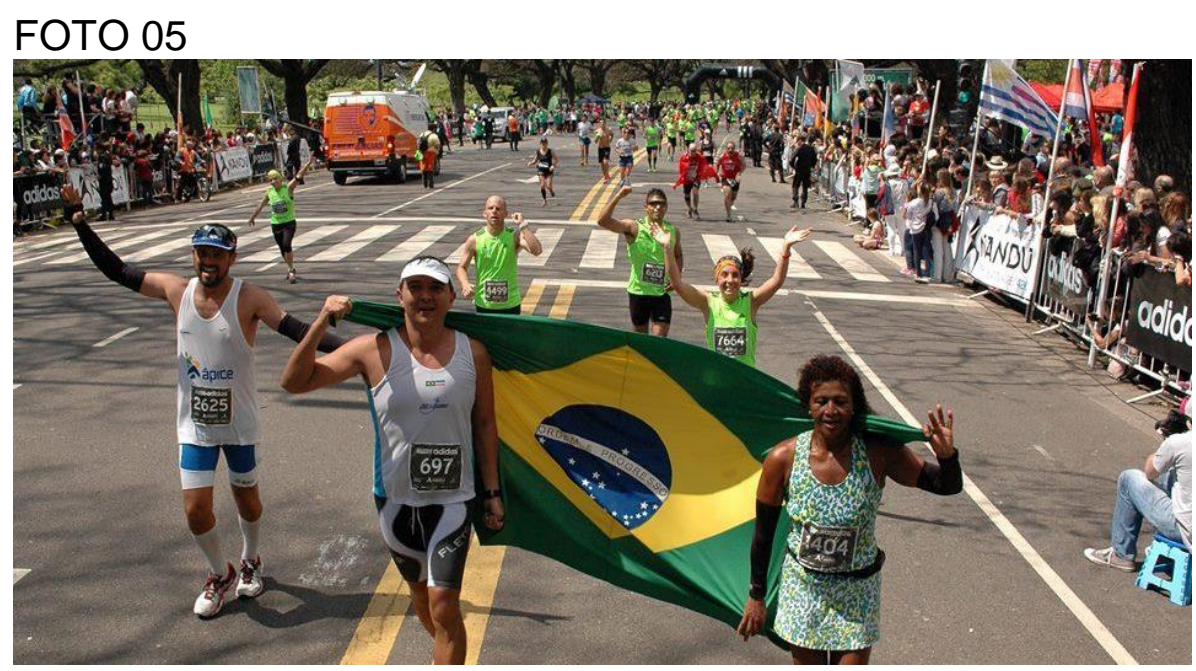

Fonte: http://maratondebuenosaires.org/pt/

Após cruzarmos a linha de chegada encontramos alguns alunos, que acabara de concluir e ali mesmo esperamos os demais e ainda mais ansioso por aguardar os que estavam realizando sua primeira Maratona (eram 4 mulheres). Logo em seguida, nos aguardando na grade após a linha de chegada, encontramos os amigos e familiares. Mais um momento de muita euforia e emoção.

Aos poucos todos chegaram e nos encontramos ao lado da chegada para então irmos ao guarda-volumes fazer a retirada de nossos pertences. Comemoramos, abrimos uma champanhe para brindar mais uma corrida e festejar as estreantes em Maratona, como na foto a seguir:

${ }^{20} \mathrm{O}$ corredor de chegada, em Buenos Aires, tem cerca de $200 \mathrm{~m}$ - onde é montada uma arquibancada em ambos os lados para que familiares, amigos e demais possam acompanhar os últimos metros dos atletas. 


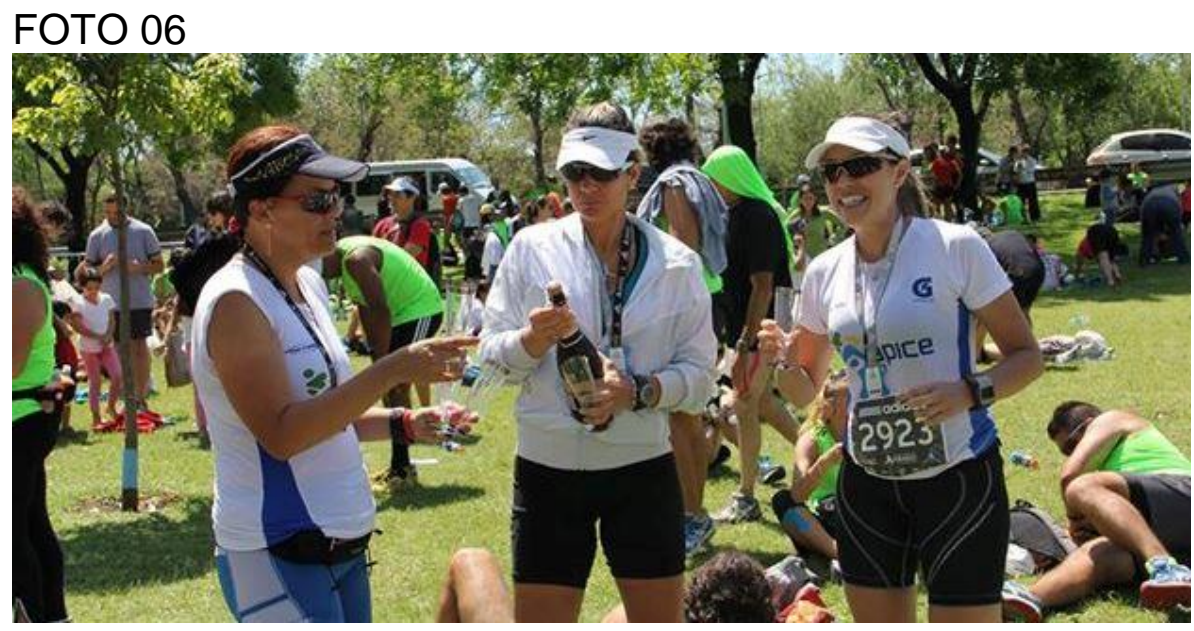

Fonte: ARRUDA (2014). Arquivo de pesquisa.

Ficamos alguns minutos debruçados sobre a grama, a fim de descansar, vestir roupas secas, calçar uma sandália para aliviar os pés, geralmente calejados ou com bolhas de sangue e aos poucos retornamos para onde estávamos hospedados. Em seguida, a maior parte do grupo se reuniu para almoçar, enquanto alguns preferiram descansar ${ }^{21}$.

Para Scalco (2010), o sentimento da chegada pode ser indescritível, um momento único para o atleta. Ela, que em seu artigo descreveu sua vivência como atleta amadora, ao cruzar a linha de chegada em sua primeira corrida na distância de 10 quilômetros expressou:

"vivi um momento subliminar de euforia quando finalmente cruzei a linha de chegada. Entreguei meu chip e recebi os cumprimentos, água e medalha. Nesse momento incorporei o papel de corredora e finalmente consegui entender um pouco sobre a grande emoção que representa para um atleta tal feito" (SCALCO, 2010, p. 329).

$\mathrm{Na}$ linha de chegada é possível observar sensações das mais diversas, rechegadas de histórias particulares de cada atleta. Ter concluído a primeira Maratona seja, talvez, a mais forte delas, pois sem dúvidas muitos sacrifícios aconteceram ao longo de sua preparação. Para os mais veteranos, na maioria dos casos, o tempo passa a ser o maior desafio. Um, dois, três minutos pode ser o motivo da maior alegria ou ainda de uma frustração sem precedentes ao se concluir uma Maratona. Ter se preparado para concluir uma prova de 42 quilômetros em

\footnotetext{
${ }^{21} \mathrm{Na}$ noite deste mesmo dia, um cansaço demasiado nos acometeu, com direito a dor de cabeça e febre. Foi então que preferi descansar enquanto os demais foram jantar e passear um pouco. A febre durou por cerca de 3 horas (entre $21 \mathrm{~h}$ e $00 \mathrm{~h}$ ) e em seguida estava bem. No dia seguinte já estava recuperado e por volta das $16 \mathrm{~h}$ nos dirigimos ao Aeroporto para então retornarmos à Brasília.
} 
menos de 4 horas e realiza-la em 4h10' não chega a ser um resultado ruim, mas a depender da expectativa dada a ela, pode se tornar uma frustação.

Para Scalco (2010), "histórias interessantes não faltam e muito menos heróis, visto que todos se sentem assim ao cruzar a linha de chegada" (SCALCO, 2010, p. 332). Cada um trás consigo as mais variadas motivações para fazer de uma corrida, e talvez ainda mais quando nos referimos a uma Maratona, a corrida mais especial possível. É preciso vivenciar o momento para se entender as lágrimas, o sorriso ou a dor do atleta que chega ao final de uma corrida.

A viagem de volta foi tranquila, embora as pernas precisassem mesmo era de espaço para descansar pelo 'desconforto do dia seguinte'. Segunda Maratona concluída em 12 de outubro de 2014, durante o primeiro semestre desta empreitada no mestrado.

\subsection{O perfil dos corredores de rua}

As pesquisas de cunho sociológico têm como uma de suas preocupações traçar o perfil dos sujeitos da pesquisa, no nosso caso o perfil dos corredores de rua. Aqui merecem menção alguns aspectos por nós elencados como fundamentais para a construção do perfil de corredores de rua. Sexo, idade, tipo físico e perfil sócioeconômico.

Com referência ao sexo, as corridas de rua, apesar de serem de cunho democrático, ainda contam com uma majoritária participação masculina, em todas as faixas de idade, como se verifica na Fotografia 07 e também no cotidiano nas largadas das diversas corridas em Brasília.

No entanto, verificamos tanto em locus quanto na literatura que, ao longo da história, as mulheres vêm ocupando cada vez mais espaços nas corridas, correspondendo a cerca de $35 \%$ por cento das inscrições em corridas tradicionais em Brasília, por exemplo. 


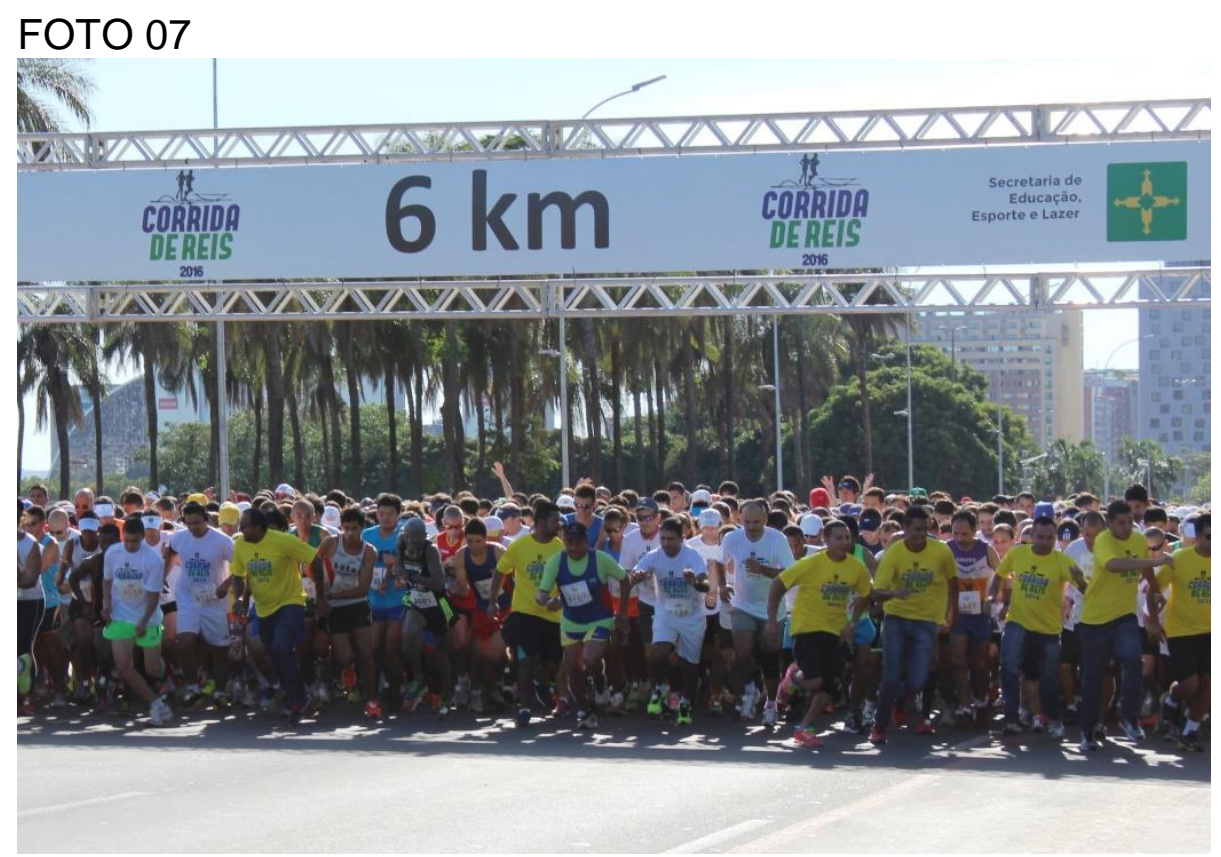

Fonte: ARRUDA (2016). Arquivo de pesquisa

Enquanto a primeira Maratona ocorreu em 1896, apenas no ano de 1972 a AAU, Amateur Athletics Union, órgão regulamentador do atletismo nos Estados Unidos, reconheceu a participação de mulheres nas Maratonas. Apenas em 1984 houvera a primeira disputa da Maratona feminina. A própria corrida de São Silvestre só admitiu a participação das mulheres, após 50 anos de existência. Em 1975, ano declarado pela ONU (Organização das Nações Unidas), como o Ano Internacional da Mulher, a prova passou a realizar inscrições do público feminino (DALLARI, 2009, p. 42).

Com relação à idade, também verificamos que em corridas de rua a faixaetária dos participantes é diversificada. Notadamente, o perfil jovem e atlético é predominante, mas isso não quer dizer que pessoas com mais de 60 anos, caracterizando como idosos, de acordo com nossa legislação, não possam participar. No entanto, o grupo de corredores por nós acompanhados, apresentava um perfil de idade entre 38457 , como se verifica na imagem a seguir: 


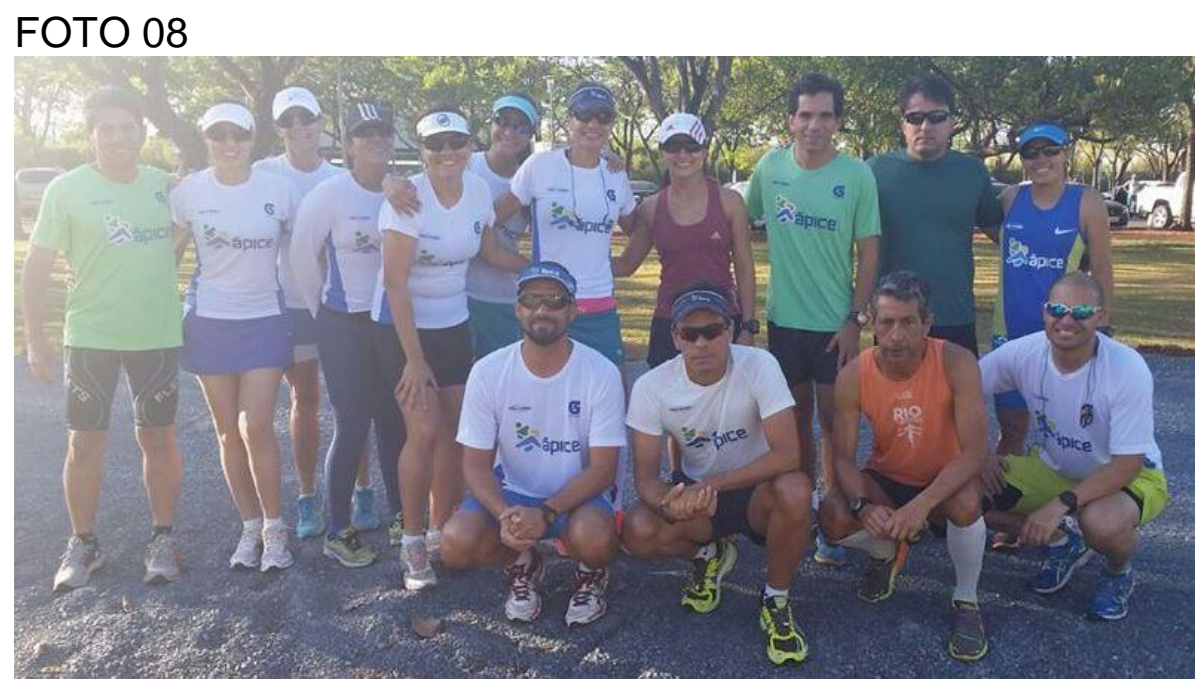

Fonte: ARRUDA (2014). Arquivo de pesquisa

Pensando em nível técnico, para ser um corredor de rua, não há impedimentos para tal prática corporal. Corredores profissionais recebem prêmios em dinheiro quando chegam nas primeiras colocações. Nesta mesma corrida, a imensa maioria dos participantes paga para correr e receber, ao final, uma medalha como reconhecimento por ter completado o percurso, independente do tempo que ele levou para completa-lo.

Ainda se tratando do perfil do corredor de rua, o 'tipo físico' não é condição de exclusão para as corridas de rua. Reconhecemos que entre aqueles que têm menor peso, passa a ser um pouco mais vantajoso no quesito tempo. No entanto, as lesões podem vir de diversas situações, inclusive entre aqueles que são mais leves e que passam a correr mais rápido, expondo-se também a maiores quantidades de lesões. Ser deficiente visual, auditivo, intelectual, ser amputado e/ou cadeirante não é motivo para não participar das corridas. Em todas as corridas há inscrições para estas categorias e percebemos uma constante participação destes atletas (amadores e profissionais).

"A norma publicada pela Confederação Brasileira de Atletismo, órgão responsável pelos eventos oficiais da modalidade esportiva no país, para a homologação e reconhecimento de corridas de rua, evidencia a situação especial dos deficientes físicos nesta atividade. Em documento de janeiro de 2008 a entidade estabelece regras para a participação de portadores de necessidades especiais, depois de fazer constar que o desporto para pessoas nestas condições é regulado e dirigido por entidades específicas. Isto é, simultaneamente reconhece não ser sua alçada a atividade física 
Nesta composição do perfil do corredor de rua, tratamos também do quanto se despende, financeiramente, para ser um corredor de rua. Em geral os custos não necessitam ser tão altos. Um tênis adequado à pisada do corredor, short e blusa basta para se correr. Quem dispõe de maior poder econômico, tem estes mesmos artigos com uma qualidade diferenciada, mas isso não estará necessariamente relacionado ao resultado da corrida. São as rotinas de treinos que tornará o corredor de rua mais bem preparado.

Em Brasília é possível se inscrever em circuitos ao longo do ano pelo valor de cinquenta reais, mas também há outras provas que custam cento e trinta reais. $\mathrm{Na}$ Corrida de Reis, que sempre acontece no mês de janeiro, nos últimos anos a inscrição foi gratuita. Independente do valor pago, em praticamente todas elas o inscrito recebe a camisa alusiva à corrida e ainda a medalha, ao final de sua participação. Hidratação durante a corrida, atendimento médico e guarda volume são outros serviços que encontramos em todas as corridas. Sendo assim, para ser um corredor de rua os custos não são altos. Paga-se o valor da inscrição quando se destina a participar de alguma corrida. Mas reconhecemos que na hora de elencar as corridas a se inscrever, bem como o local onde ocorrerá a corrida, o poder econômico do atleta passa a ser algo determinante. 


\section{CAPÍTULO II - "VOU COMPLETAR, MESMO QUE SEJA UM SACRIFÍCIO"}

O título do capítulo "vou completar, mesmo que seja um sacrifício" foi construído com base na fala de um dos nossos sujeitos de pesquisa, durante uma corrida de rua realizada no ano de 2016. Ao nos apropriarmos de sua fala, temos o propósito de relacionar a noção do sacrifício corporal com o nosso objeto de estudo, a corrida de rua. Com essa intenção desenvolveremos alguns conceitos considerados importantes para o entendimento do sacrifício no âmbito dos estudos das ciências sociais, tendo como norte o sacrifício do corpo de atletas amadores de rua na realização de seus objetivos, a saber: concluir uma corrida.

\subsection{Os Sacrifícios na Educação Fisica: o que dizem as publicações nas revistas científicas}

Como parte da metodologia deste trabalho, realizamos uma pesquisa sobre o tema sacrifício e as publicações em cinco das principais revistas de educação física no Brasil, a fim de percebermos como o temática do sacrifício é entendida na educação física. As revistas em questão são: Revista Movimento (ESEF/UFRGS Escola de Educação Fisica da Universidade Federal do Rio Grande do Sul), Revista Brasileira de Ciências do Esporte (RBCE), Revista Motrivivência (UFSC Universidade Federal de Santa Catarina), Revista da Educação Física (UEM Universidade Estadual de Maringá-SP) e Revista Pensar a Prática (FEFD/UFG Faculdade de Educação Física e Dança da Universidade Federal de Goiás). A opção por estas revistas foi tomada por serem publicações cujos temas pesquisados e publicados são bem diversificados no âmbito da educação física no Brasil. Os artigos encontrados foram publicados num período recente de 10 anos (entre $2006 \mathrm{e}$ 2015) no qual a palavra SACRIFÍCIO deveria estar presente nas palavras chaves ou no resumo do artigo ou mesmo no corpo do texto completo.

Foram encontrados 7 (sete) artigos com a palavra Sacrifício (no título, nas palavras-chaves, no resumo ou no corpo do texto), no entanto um deles tratava da palavra sacrifício como uma referência que se distancia de nosso objetivo de estudo e, portanto, consideramos 6 (seis) artigos contemplando estes critérios descritos no 
parágrafo anterior, no qual 2 (dois) deles publicados na Revista Movimento e os 4 (quatro) restantes na Revista Pensar a Prática. As próximas linhas estão dedicadas a realizar um apanhado dos pontos que julgamos relevantes para este trabalho presentes nestas publicações.

Nos 6 artigos que ora serão objeto de rápida análise, verificamos a palavra sacrifício e os sentidos dados a ela, ao tempo em que observamos haver direcionamentos ou conceituações diversos. Elencamos aqui alguns ambientes distintos a partir das publicações: as academias de ginásticas e também academias de lutas para homens e mulheres; o ambiente escolar (incluindo aqui a discussão do mundo do trabalho - infantil e também adulto); e, também nas corridas de rua (como nas corridas de aventura e nos 'esportes de sacrifício'). Em nenhum dos artigos analisados ocorreram discussões sobre temas voltados para a biologia ou fisiologia do exercício e nem da biomecânica, temas que não nos debruçamos nesta pesquisa. A ordem de apresentação dos artigos foi realizada cronologicamente, por ano de publicação.

O primeiro artigo em questão, intitulado "Reflexões de passagem sobre o lazer: notas sobre a pedagogia da indústria cultural" (Revista Pensar a Prática, 2006) direciona-se para o campo da imagem do corpo e a 'indústria da beleza', no processo de massificação da cultura corporal. Discute ainda a relação entre o trabalho e o lazer, no tempo 'livre'. Na primeira citação, o autor Alexandre Fernandez $\mathrm{Vaz}^{22}$, dá a devida e necessária importância para o momento de lazer, como uma forma de celebrar a dor, o sacrifício e o sofrimento vivenciados no ambiente de trabalho. Para o autor, o termo sacrifício, neste contexto, é o que o trabalhador(a) vivencia no ambiente do trabalho, com atividades repetitivas e cansativas em suas rotinas. Assim ele afirma: "Ao processo de trabalho na fábrica e no escritório, só se pode escapar adaptando-se a ele durante o ócio" (VAZ, 2006, p. 18), e é neste ócio que se celebra o sacrifício.

Numa segunda citação sobre o sacrifício, o autor constrói uma analogia entre os shoppings centers e as academias de ginástica, afirmando que ambos são territórios de consumo de corpos em seus rituais de sacrifício. Ele traz à reflexão o ambiente de compras e o consumo de produtos diversos e também as academias de ginásticas, como sendo ambientes propícios para serem consumidos produtos de

${ }^{22}$ Doutor em Ciências Humanas e Sociais e professor na UFSC - Universidade Federal de Santa Catarina e Pesquisador CNPq. 
satisfação de desejo para o próprio corpo. Todavia, o autor nos traz duas novas abordagens sobre o termo sacrifício, sendo o primeiro associado ao trabalho, como um ambiente cansativo, de sofrimento e de sacrifício. No segundo momento, neste caso mais associado ao exercício físico, o sacrifício assume uma relação com as atividades realizadas dentro das academias de ginástica, em virtude do desejo de adquirir um corpo à altura de uma sociedade consumista.

Publicado na Revista Pensar a Prática no ano de 2007, o segundo artigo que pesquisamos nesta empreitada, de título: Dor e tecnificação no contemporâneo culto ao corpo, de cunho etnográficos, os autores Giselle Torri ${ }^{23}$, Jaison Bassani ${ }^{24}$ e Alexandre Vaz lançam mão de técnicas como observação participante, entrevistas e descrição de atores pesquisados em um academia de ginástica em Florianópolis, próximo a uma universidade pública. Após ampla descrição sobre o ambiente pesquisado e seus arredores geográficos, os autores adentram o universo da academia de ginástica, no intuito de investigarem as motivações que fazem os frequentadores estar naquele ambiente, bem como descrevem algumas atitudes dos professores a fim de motivarem seus alunos a se exigirem ao máximo neste ambiente.

É assim que eles afirmam categoricamente que "o enfrentamento da dor, do sofrimento, do sacrifício e da privação é frequentemente encarado como algo corriqueiro e "normal" por parte dos frequentadores de academias" (TORRI, BASSANI e VAZ, 2007, p. 266). Aqui o tema sacrifício retoma sua ideia de dor e sofrimento ao se realizar o exercício, exigindo de quem o pratica, o máximo de desgaste para se alcançar um objetivo, talvez muito além de suas possibilidades.

Em outra citação, é possível interpretar que para os participantes das academias, o sofrimento corporal e o sacrifício durante o exercício passam a ser absorvidos como um processo de "naturalização". É como se disséssemos que sem dor e sem privação (enquanto se exercita), não haverá bons resultados e assim este passa a ser encarado como um processo 'normal' ou natural. Será mesmo que sem a dor e o 'sacrifício' durante as sessões de exercícios, sejam eles dentro das academias ou nas corridas de rua, não será possível alcançar resultados satisfatórios? Questionamos desta forma porque nos soa uma contradição o exercício (entre praticantes amadores) ter por objetivo a melhoria da 'qualidade de

${ }^{23}$ Especialista em Educação Física Escolar pela Universidade Federal de Santa Catarina (UFSC);

${ }^{24}$ Doutor no Programa de Pós-graduação em Educação da UFSC. 
vida' de quem o pratica, tendo que se expor a níveis de dor e de sacrifício. Por todo o artigo, a palavra sacrifício é citada apenas 2 (duas) vezes, sendo uma delas em um dos subtítulos do artigo, porém a riqueza sobre o tema se estende por toda pesquisa, sendo também um artigo de grande importância e reflexão para nosso trabalho.

O trabalho seguinte, "O corpo e as técnicas para o embelezamento feminino: esquemas da indústria cultural na Revista Boa Forma" escrito por Beatriz Albino ${ }^{25}$ e Alexandre Vaz, tendo sido publicado na Revista Movimento em 2008, fez uma ampla análise de uma revista comercial da editora abril, nas edições de alguns meses (no período do ano que compreende a estação do verão) entre os anos de 2001 e 2006. No artigo, temas como liberdade, felicidade e aparência do corpo tomaram relevância, mas sempre voltados para o público feminino (que é o público para qual se destina a revista). No artigo, a palavra sacrifício fora citada 10 vezes (desde o resumo até a conclusão), sendo assim uma palavra importante durante todo a pesquisa, mencionamos a seguir os trechos que pudemos identifica-la:

"...ensinar a mulher a fazê-lo por meio da dureza, da disciplina e do sacrifício." (ALBINO e VAZ, 2008, p.211)

“Na batalha contra as 'vontades' ...que é a de comer, é imprescindível ter disciplina e se submeter a sacrifícios em nome da Beleza." (ALBINO e VAZ, 2008, p.212)

"O sacrifício exigido justifica-se nos escritos da Boa Forma em benefício de uma satisfação futura, já que é somente um meio para o alcance do prazer prometido." (ALBINO e VAZ, 2008, p.212)

"No processo de potencialização do corpo, o sacrifício é a condição exigida para que se possa conhecê-lo e dominá-lo." (ALBINO e VAZ, 2008, p.213)

"Nesse processo, entendido como civilizador, o sacrifício se faz presente por meio da renúncia e do controle de si." (ALBINO e VAZ, 2008, p.213)

“...a própria mulher deve reconhecer e exercer, por meio do sacrifício, da racionalização e do esquadrinhamento de seu corpo." (ALBINO e VAZ, 2008, p.217)

\footnotetext{
${ }^{25}$ Doutora em Ciências Humanas pela UFSC
} 
Neste contexto, a palavra sacrifício é posta, como elemento principal, num processo de renúncia frente aos objetivos a serem alcançados. Objetivos estes sempre voltados para a vaidade e a beleza do corpo. A palavra satisfação é tomada também como consequência do sacrifício vivido em favor do objetivo esperado. A relação entre 'o melhor resultado' esperado para o próprio corpo parece ter uma relação direta com o 'fazer um sacrifício'.

Para analisar a noção de sacrifício apresentada nos trechos extraídos do artigo acima, nos apoiamos em Mauss e Hubert, para quem "não há sacrifício em que não intervenha alguma ideia de remissão" (MAUSS e HUBERT, 2013, p. 107). O texto assim nos direciona a um contexto de renúncia daquilo que é prazeroso, divertido, desprendido e descompromissado para então passar a oferecer, como forma de adequação ao corpo ideal, um universo de elementos racionais, rígidos, dolorosos e disciplinares, como alimentação regrada e rotina de exercícios rigorosos.

O quarto artigo analisado (publicado pela Revista Movimento, em 2008), de título: "Controle de si, dor e representação feminina entre lutadores(as) de Mixed Martial Arts", conhecido como MMA, é de autoria de Samuel Oliveira Thomazini ${ }^{26}$, Cláudia Emília $^{27}$ Moraes e Felipe Almeida ${ }^{28}$, publicado em 2008. Os autores realizaram uma etnografia por sete meses, tendo sido realizada a técnica de observação participante e entrevistas semi-estruturadas. Além de ter registrado com fotografias e vídeos nos locais dos treinos e provas.

Nas quatro passagens em que o Sacrifício é citado, percebemos a forma, arriscaríamos dizer, mais 'tradicional' de associação do termo, inclusive sem citações referente à palavra, em que a palavra sacrifício é relacionada à dor física. Seja no depoimento relatado de alguns 'lutadores', seja descrita pelo autor, seja no ambiente de treino ou nas competições, o sacrifício tem por objetivo a superação da dor em busca da melhor performance quando se compete ou se treina. Passa assim a ser uma condição "naturalizada, graças ao desenvolvimento de uma pedagogia baseada no controle e na racionalização da dor" (THOMAZINI, EMÍLIA e ALMEIDA, 2008, p. 288).

\footnotetext{
${ }^{26}$ Mestre em Educação Física pela Universidade Federal do Espírito Santo (UFES)

${ }^{27}$ Mestre em Educação pela UFES

${ }^{28}$ Doutor em Educação e professor adjunto pela UFES
} 
Os autores vão mais além quando ele adentra na relação da presença das mulheres nos ambientes de luta. Em suas entrevistas, o autor nos revela que para muitos homens (lutadores), o ambiente das academias de lutas é predominantemente voltado para o público masculino. A cultura viril, forte, musculosa, no enfrentamento da dor e de corpos definidos para a luta ainda predomina entre os homens. Uma tentativa adequada à discussão, a de gênero, revela que para a maioria dos homens entrevistados, a luta é 'coisa' só para homens.

Tomando gancho nesta discussão, a presença das mulheres no ambiente das corridas de rua também tem tomado maiores proporções no número de inscritas participantes das corridas. Em algumas capitais brasileiras, bem como em Brasília, ao longo do ano há algumas corridas que são exclusivamente para a participação das mulheres, como a flower run (que ocorreu em março de 2016), a wrun (uma meia maratona que acontece nas cidades de São Paulo e Rio de Janeiro), dentre outras tantas. Ao contrário de alguns resultados encontrados pelo autor do último artigo que analisamos, nas corridas de rua nos parece haver uma aceitação de sua presença, inclusive com propósitos de aceitação e acolhimento ao público feminino, dedicando provas exclusivas para mulheres.

No quinto artigo analisado, que tem por título: "Sobre corporalidade e escolarização: contribuições para a reorientação das práticas escolares da disciplina de educação física", publicado em 2008 na Revista Pensar a Prática, os professores Marcus Aurélio Taborda de Oliveira ${ }^{29}$, Luciane Paiva Oliveira ${ }^{30}$ e Alexandre Vaz, nos ampliam o horizonte da temática sacrifício vinculando ao mundo do trabalho na discussão advinda da educação.

A pesquisa acontece num contexto escolar, no qual se propõe uma Educação Física voltada para a corporalidade e humanização das aulas de educação física que busca romper com as aulas apenas baseadas nas competições advindas do Esporte e do movimento vindos da motricidade, sugerindo assim um encaminhamento de atuação do trabalho docente, no estado do Paraná em torno de alguns eixos de discussão. São eles: 1. O corpo que brinca e aprende:

\footnotetext{
29 Doutor em Educação pela Pontifícia Universidade Católica de São Paulo (PUC-SP) e prof. Associado pela Universidade Federal de Minas Gerais (UFMG);

${ }^{30}$ Doutora em Educação pela PUC-SP e professora adjunta pela Universidade Federal do Paraná (UFPR).
} 
manifestações lúdicas; 2. Potencial expressivo do corpo; 3. Desenvolvimento corporal e construção da saúde; 4. Relação do corpo com o mundo do trabalho.

Um novo direcionamento é dado para a palavra sacrifício, que neste contexto não se aplica ao esporte e nem ao esporte de competição, por isto desta forma não iremos nos aprofundar no artigo, mas também não descartaremos o trabalho, pois ele nos amplia a temática do sacrifício publicado em revista de nosso interesse, além disso, nos abre a mente para novas dimensões do tema em questão.

A palavra sacrifício é citada 4 vezes ao longo do artigo na discussão do direcionamento das aulas de educação física no ambiente escolar. Para a aplicação dos eixos propostos durante as aulas de educação física, o autor ressalta que é preciso superar a visão, muitas vezes fragmentada, que os professores têm do ser humano e da cultura. É preciso assim ir além de uma visão, comumente percebida apenas a partir de um conjunto de ossos, músculos e nervos.

Apenas nos eixos 3 e 4 aparecem a palavra sacrifício e o contexto está relacionada à saúde, como uma conquista coletiva e constante, válida por toda vida e não apenas que ela deva ser alcançada com dor e sacrifício. A saúde deve acontecer num processo 'natural', fruto da coletividade, num ambiente em que hajam políticas públicas que permitam a todos uma vida saudável. Enfim, não é pelo esforço ou sofrimento individual que a saúde é promovida, mas fruto de uma ação coletiva.

Por fim, no eixo 4 (quatro), retomamos ao estudo de Vaz (2006), analisado anteriormente, que faz uma relação entre o ambiente de trabalho e o sacrifício do corpo do trabalhador, num contexto, muitas vezes, carregado de injustiças. Aqui o autor vai além, discutindo a exploração da força do trabalho; ele destaca também a exploração do trabalho infantil, em que crianças são levadas à prostituição desde cedo, bem como adolescentes e jovens que são expostos à exploração sexual e pornográfico. Cita também o mundo do trabalho infantil no campo e também nos centros urbanos, no qual muitas vezes os próprios alunos são submetidos a longas horas de trabalho (de sacrifícios), os impedindo de terem uma vida saudável e digna, comprometendo, por consequência, seu desenvolvimento humano. Aqui o sacrifício do corpo expressa as marcas desse lado desumano do trabalho.

Por fim e publicado na revista Movimento em 2013, sobre o título: "EI deporte, proyección, espejo y símbolo cultural: reflexión sobre los deportes de 
sacrificio y su transmisión de valores en el contexto socioeducativo" (Esporte, projeção, espelho e símbolo cultural: reflexão sobre os esportes de sacrifício e sua transmissão de valores no contexto socioeducativo) este é o artigo que, sem dúvida mais nos aproxima da discussão posta neste trabalho. Seu autor, Roberto Cachán Cruz $^{31}$, traduziu bem o 'sentimento' existente entre o termo sacrifício e os esportes que ele intitulada de: esportes de sacrifício; sendo estes os esportes de longa duração, como a Maratona ou o Ironman (triatlo que envolve as modalidades natação, ciclismo e corrida). Em uma de suas versões clássicas, o Ironman tem por distâncias 1900 metros de natação, 180 quilômetros de ciclismo e 42 quilômetros de corrida (Maratona). Para ele, os esportes de sacrifício (segundo ele esportes contemporâneos) parecem apontar para projetos, representações e valores que o corpo e a mente vão adquirindo em nossa sociedade.

"El deporte de sacrificio es una manifestación de nuestro tempo donde las situaciones personales parecen estar por encima de las deportivas a la hora de fijar sus motivaciones, generando además sólidas expectativas en el terreno educativo, sobre todo a través de los medios de comunicación. En línea con esa perspectiva, este estudio considera que el deporte construye una serie de creencias, sentimientos y comportamientos que se vivencian en forma de ritual, incitando auna especifica orientación hacia el sacrificio." (CRUZ, 2013, p. 330)

No artigo, o autor faz uma reflexão pertinente entre os valores do 'esporte do sacrifício' e o surgimento de valores arcaicos, o sincretismo religioso, o culto extremo ao corpo e assim chegando ao esporte de sacrifício. Características como o culto ao corpo, o apoio ao colega que com ele compete, o cumprimento de distâncias longas ou em terrenos de extrema dificuldade, como as corridas de montanha ou as competições de bicicleta em longa duração com terrenos de alto grau de dificuldade.

Isso ainda remetendo ao cuidado com o corpo e alimentação com suplementações de alto custo financeiro, a dedicação rigorosa com a alimentação, sem falar naqueles que cuidam do corpo com tal dedicação após cada sessão de treino ou competição, expondo seus corpos a baixíssimas temperaturas dentro de 'baldes' de gelo ou investindo em massagens e terapias para o corpo, a fim de obter

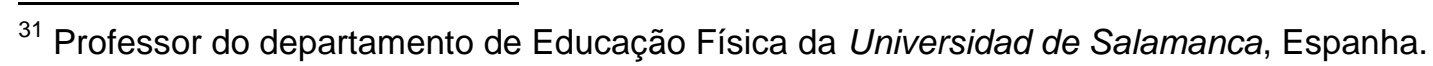


o máximo de repouso após a exposição prolongada e contínua de seus corpos durante o esporte.

O autor faz ainda um paralelo entre os esportes de sacrifício e os rituais de passagens de origem indígena. Assim como o índio de menor experiência passa por um ritual em que seu corpo é exposto à dor, que muitas vezes deixam marcas, os que buscam os esportes de maior exposição do corpo também sofreriam um processo de ritual de passagem, como cumprir uma meia maratona (21 quilômetros) e passar a se preparar para correr a Maratona.

"Se ha establecido entonces una ritualística emergente, un instinto de modelo deportivo para el esfuerzo, de superación y de sufrimiento, aumentando su práctica sobre todo en grupos sedentarios. Entre estas actividades destacamos los deportes de ultrafondo, maratones singulares (de montaña, en condiciones climáticas severas, em desiertos), ascensos a cumbres sin oxígeno, los 100 kilómetros, el triatlón o el Camino de Santiago. Estas disposiciones nos aproximan a una realidad que parece tener respuesta en determinadas poblaciones deportivas: al igual que se recuperaron las termas em sofisticados spas y ciudades termales, se están recuperando las roezas físicas épicas." (CRUZ, 2013, p. 324).

O autor ainda cita dois estudos que apontam como principais fatores para os corredores se disporem a treinar e completar a Maratona, que são: o prazer de correr e alcançar seus objetivos e realizações pessoais e também que a conclusão da Maratona estaria ligada muito mais ao alcance de uma meta pessoal do que a importância pelo desempenho físico.

$E$, por fim, ainda sugere que há um desejo dos atletas atuais em se relacionarem com suas ancestralidades, com a origem do homem. Para tal fenômeno ele chama de "comportamento fóssil". Neste sentido seria um desejo dos homens a prática pela atividade de longa duração com baixos índices de lesões, sendo isto fundamental para ir mais longe. Como na obra intitulada "Nascidos para correr", um best-seller escrito pelo jornalista nascido nos Estados Unidos, Christopher McDougall, que se dedicou a pesquisar uma tribo indígena no México, os Tarahumaras e que têm por hábito percorrer longas durações usando apenas uma sandália de couro, tendo como princípio a corrida 'natural' e com a menor 
possibilidade de lesão. Há inclusive uma ultramaratona nesta mesma cidade, com 82 quilômetros de distância para serem percorridas (sendo assim uma ultramaratona), onde a maior parte dos competidores são os nativos deste lugar. Além dos 82 quilômetros a serem percorridos, os participantes têm que se expor a dificuldades que exige muita preparação, física e psicológica, como altitudes demasiadas altas e temperaturas elevadas.

Abrimos aqui um breve relato sobre algumas destas corridas, definida neste trabalho como esportes de sacrifícios, pois já estivemos presentes em algumas delas, como a ultramaratona de revezamento da cidade de Santa Catarina, intitulada de Volta à llha e também da ultramaratona de revezamento de Brasília, realizada anualmente no mês de junho, onde o clima nesta cidade tem o início de característica fria e seca nas primeiras horas do dia e à noite. Já durante o dia o clima é quente e também seco. A Volta do Lago é uma ultramaratona que pode ser realizada individualmente (categoria solo) e também por revezamento (com equipes que podem variar de 3 até 8 participantes). A prova principal tem distância em todas as categorias de 100 quilômetros, onde o percurso se estende ao redor de todo lago Paranoá. Desde 2008 que participamos desta ultramaratona (sempre em equipe), sendo a mais difícil delas na categoria trio (equipe com três atletas). A conclusão da corrida deve acontecer, para as categorias de equipe, em até 10 horas consecutivas e de 12 horas para a categoria solo. Durante o percurso há 14 trechos pré-definidos pela organização da prova e cabe a cada equipe dividir, antecipadamente, os trechos entre os participantes.

Além destas (que são ultramaratonas coletivas), estivemos presentes também em algumas corridas 'fora do asfalto', conhecidas como 'corrida de aventura' ou 'corrida de montanha'. Em Brasília há diversas corridas ao longo do ano que se incluem nesta categoria, bem como na cidade de Pirenópolis - GO, iniciada em 2013 acontece a 21k Piri.

Esta última também poderia ser incluída como um esporte de sacrifício, pois além de ter um percurso de 21 quilômetros, a corrida tem dificuldades, como grandes altitudes e alta temperatura que aumentam consideravelmente o esforço necessário para sua conclusão. Ao longo dos 21 quilômetros a serem percorridos pelos atletas, é possível constatar com muita frequência o 'sofrimento', a dor e o 'sacrifício' necessário para se concluir toda distância. Fisicamente, eventos como 
câimbras ou dores musculares, bem como quedas provocadas por um percurso de muita dificuldade, apresentando-se durante o percurso pedras soltas, lama, terreno escorregadio, galhos e troncos de árvores, dentre outros; expressões faciais de desconforto e cansaço (físico e também mental), nos faz perceber que os esportes de sacrifícios são corriqueiros entre aqueles que praticam esta prática corporal, apesar das tantas dificuldades apresentadas em corridas com esta natureza.

Numa de nossas entrevistas a atleta relata um trecho sobre sua Maratona, relatando uma angústia sobre a possibilidade de parar e abortar a corrida: "Mas naquele dia eu dizia: 'Não, já estou realmente chegando, vou seguir em frente, vou até onde der'. E onde não desse, eu realmente ia caminhar e ia chegar até o final." (Maurine).

Completando ainda tais dificuldades, tendo concluído corridas com esta natureza, eventos como calos de sangue e bolhas nos pés são um tanto comum entre os participantes, além disso, as dores musculares que se perduram por alguns dias após a corrida, só aumentam esta sensação de desconforto gerada pelo evento, sendo estes, resultados positivos, visto por autores como Albino e Vaz (2008, p. 205).

\subsection{Sobre o Sacrifício}

Faz-se aqui apologia ao título da obra de Mauss e Hubert (2013), para quem o sacrifício possui uma estrutura que o organiza.

Referimo-nos a uma estrutura formada pelo momento da entrada do sacrifício, pelos elementos: sacrificante, sacrificador, o lugar e os instrumentos utilizados no sacrifício. O sacrificante é aquele que oferece o sacrifício, o sacrificador é o mediador (ou o Sacerdote) do sacrifício a ser ofertado e o lugar e os instrumentos devem ser utilizados no ato do sacrifício: "o próprio local da cena deve ser sagrado" (MAUSS e HUBERT, 2013, p. 33). E finalmente a saída do sacrifício, ou seja, é o ato conclusivo do sacrifício realizado.

Existe ainda uma série de tipos ou denominações de sacrifícios e suas estruturas que pretendem explicar o contexto no qual ele acontece. Sacrifícios expiatórios, sacrifícios de ação de graça, bem como sacrifício por demanda. Eles podem se dividir ainda em constantes ou ocasionais, compreendemos isto a partir da frequência pelo qual ele acontece. São bem amplas as categorias encontradas 
por Mauss e Hubert, mas talvez o mais importante afirmado por eles seja: "na verdade os limites dessas categorias são indecisos, sobrepostos, muitas vezes indiscerníveis; as mesmas práticas se verificam em certo grau em todas" (MAUSS e HUBERT, 2013, p. 22).

Esta afirmação nos deixa claro que a estrutura sugerida na organização do Sacrifício, para Mauss e Hubert, é um tanto flexível, aberta a interpretações que possam trazer a este trabalho, um enriquecimento prático e claro na relação entre o Sacrifício e a Corrida de Rua, ao passo que as fases da estrutura do sacrifício, citada anteriormente, se adequam com facilidade ao que reconhecemos como fundamental para a preparação de uma corrida.

Gláucia De Mello, indo em acordo com Mauss e Hubert, no que se refere à teoria do sacrifício, faz uma reflexão ainda mais profunda quando o assunto é sacrifício, indo além, tomando o sacrifício como redenção, merecimento, busca pelo sagrado e pelo desapego. O sacrifício torna-se o meio para obter o merecimento ao universo sagrado. "Se quisermos reconquistar o paraíso, precisaremos provar a nossa descendência divina pelo exercício de solidariedade, de compaixão e pureza de propósitos" (DE MELLO, 2015, p. 12).

Mas afinal, o que é Sacrifício? Ao contrário do que parece, o sacrifício nem sempre carrega em seus rituais a dor ou o sofrimento, não ao menos humano. Muitos rituais de Sacrifício se utilizam de animais ou alimentos como vítimas de oferenda ou como elemento a ser sacrificado e não o próprio corpo (humano), assim como os rituais apresentados por Mauss e Hubert. No entanto, em algumas tribos citadas na obra, a vítima podia ser algum membro dela. Nestes casos, o sofrimento era eminente. Mas mesmo assim a importância do Sacrifício é, em essência, a mesma.

Isto também fica claro nas religiões contemporâneas, quando vemos um romeiro ou um 'penitente' subir centenas de degraus de joelho ou mesmo com um peso levado na cabeça ou em suas costas, afim da busca da redenção ou penitência, em busca de algo a ser alcançado ou em agradecimento por alguma graça. Estes também poderiam ser exemplos claros de rituais de sacrifício na presença da dor e do sofrimento humano.

Para Rigoti (2008, p. 89) o sacrifício é composto de atos e rituais que servem para colocar em contato o mundo do sagrado e do profano, justificando assim que o 
Sacrifício é, em essência, um ritual de ordem religiosa de povos primitivos, mas que se faz bastante atual.

\subsection{Contextualizando o tema Sacrifício nas Corridas de Rua}

Por algumas vezes nos foi questionado por amigos e alunos (corredores de rua) sobre qual a importância de pesquisar sobre o tema sacrifício associado à corrida de rua. O questionamento se faz no sentido de parecer não acreditarem ser este um tema relevante para o cotidiano vivido por nós, que corremos. Percebi então que o tema sacrifício tem mesmo, em sua essência, uma relação fundada com a 'questão do sagrado' e por vezes, do religioso, o que poderia desta forma, não ser relevante para ser estudado, visto que a corrida de rua se materializa na esfera do profano ou mundo da rua (DAMATTA, 1997) ${ }^{32}$. Mas fomos à busca de argumentos para entender uma possível relação e isto se deu num dado momento quando um de nossos alunos em um determinado treino (com 22 quilômetros) me falou após ter concluído 10 quilômetros: "vou completar, mesmo que seja um sacrifício"!

Portanto, o tema do sacrífico deixa de ser apenas uma conjectura e passou a ser evidenciado nas informações de campo, à medida que um dos sujeitos da pesquisa, enfatiza literalmente essa expressão, que de antemão já imaginávamos ser um aspecto importante a buscar o entendimento na temática da corrida de rua. Então, nos questionamos: se em princípio a noção de sacrifício está associada ao âmbito do sagrado, como ela poderia estar presente nas corridas de rua, uma prática corporal que, em tese, nada tem a ver com a dimensão religiosa da humanidade? Buscaram-se assim alguns estudos que pudessem primeiramente nos esclarecer um pouco mais sobre o sacrifício e desta forma, posteriormente, entendermos a relação que a corrida de rua possa nos revelar.

Mauss e Hubert nos ajudam a conhecer, diria que profundamente, as teorias do sacrifício, em sua obra intitulada "Sobre o Sacrifício", cuja primeira edição é de 1899, mas que possuímos a de 2013. Mauss e Hubert foram os primeiros a sintetizar as diversas teorias sobre o sacrifício. Para eles, há um universo que está sendo

\footnotetext{
${ }^{32}$ Aproveita-se aqui de duas noções básicas dos estudos socioantropológicos. A primeira diz respeito a separação já reconhecida entre sagrado e profano, que ganha evidência a partir dos estudos de Marcel Mauss. A segunda está relacionada à diferenciação entre a esfera pública e a esfera privada, que pode ser encontrada nos estudos realizados por DaMatta (1997) quando o mesmo se remete à clara distinção entre os aspectos cotidianos que separam a vida privada - restrita muitas vezes ao munda da casa - e aqueles que estão relacionados à esfera pública, o mundo da rua.
} 
influenciado quando ocorre um sacrifício. Participa do ato do sacrifício aquele que o oferece, aquele ou aquilo (animal, por exemplo) que é sacrificado, aquele que conduz a cerimônia do sacrifício e até os familiares próximos daquele que ofereceu o sacrifício. Independente da distância de uma corrida à ser concluída, por diversos motivos percebemos acontecer no corpo de quem corre, um sacrifício.

Ao longo dos últimos 8 (oito) anos de imersão profissional e pessoal com a corrida de rua ${ }^{33}$, com um olhar mais sensível, durante uma corrida de rua, é possível perceber o quanto os atletas expõem seus corpos a um sacrifício. É bastante comum perceber nas expressões corporais dos atletas mais cansados durante uma corrida, um sofrimento que se assemelha ao que podemos traduzir como sacrifício do corpo. Podemos aqui trazer o exemplo de uma atleta que se dispôs a correr num mesmo ano (em 2014), cinco Maratonas e que de fato completou, mas às duras penas. Pequenas lesões (em geral articulares e/ou musculares) que poderiam tê-la feito parar de correr, talvez por muitos anos, sob advertência médica; mas sua insistência em completar um desafio pessoal, a fez concluir as Maratonas que se dispôs.

Esta é uma situação que extrapola a normalidade (embora seja possível contar algumas histórias como esta neste ambiente da corrida de rua), mas casos mais simples como bolhas e calos de sangue nos pés, unhas que se machucam tanto ao longo de uma corrida a ponto de cair após alguns dias, queimaduras causadas por excesso de exposição ao sol por longa duração, dentre outros, são algumas das formas em que expomos nosso corpo a um verdadeiro sacrifício enquanto corremos e também após.

Dráuzio Varella ${ }^{34}$, em recente obra, Correr - o exercício, a cidade e o desafio da Maratona, nos relata com detalhes o quanto ele sofreu para completar a Maratona do Rio de Janeiro ${ }^{35}$ em 2013, ano em que nesta mesma prova corremos a meia maratona na companhia de diversos alunos:

\footnotetext{
${ }^{33}$ A primeira corrida que participamos enquanto assessoria esportiva, atuando como estagiário, foi na 9a edição da Meia Maratona Internacional da Caixa, que acontece no Eixo Rodoviário Sul e Norte;

${ }^{34}$ Médico, cientista e escritor, correu sua primeira Maratona em Nova York no ano de 1993, ano seguinte ao seu aniversário de 50 anos;

${ }^{35}$ A Maratona Internacional do Rio de Janeiro ocorre desde 1979 e em seu formato atual (a desde 2003) passou a ter também o percurso de Meia Maratona - atualmente a corrida tem por nome oficial Maratona Caixa da Cidade do Rio de Janeiro.
} 
Ao chegar à praia de Botafogo, com o Pão de Açúcar e os barcos da enseada, minhas pernas já não me pertenciam, meus mamilos deixavam duas rodas concêntricas de sangue na camiseta, as unhas dos pés doíam, o sol ofuscava os olhos, a careca desprotegida ardia sob aquela bola de fogo que não dava um minuto de trégua. O corpo era um fardo torturante, impermeável à menor sensação de prazer. A fisionomia de meus companheiros de infortúnio não pode ser mais lamentável. É possível que achassem o mesmo da minha. Como fui esquecer o esparadrapo e o boné, em pleno Rio de Janeiro? E as unhas dos pés, que nunca havia machucado? Pela primeira vez, iria perdê-las como tantos maratonistas? (VARELLA, 2015, p. 90).

Ao questionar um dos entrevistados se o mesmo já havia participado de alguma corrida sentindo dor, eis a resposta:

“... agora, se você está com lesão, como eu corri, realmente corri com lesão do tendão, tendão de Aquiles da perna direita, doendo e com medo até, né, de rompimento e tudo, mas dentro do que eu vi do nível de lesão, que eu tinha feito exame, não era dos mais graves. Então, doía o tempo todo, dificultava de eu correr, mas dava, dava para correr. Eu fiz meia maratona de montanha que foi Pirenópolis, prova dolorida o tempo todo. E cheguei, né? Então essa é a dor que mais dificultou" (Paulo).

Ainda sobre correr sentindo dor, outra entrevistada respondeu, se referindo a ter corrido uma de suas Maratonas: "Insisti correndo, mesmo com o movimento irregular, e levei isso até o final. Assim que eu ultrapassei a linha de chegada, eu procurei imediatamente a tenda do atendimento médico” (Jackeline).

Ainda sobre o tema, um terceiro entrevistado assim descreveu seu sentimento após ter sofrido uma queda durante uma corrida de montanha: “...Nessa prova, realmente, eu confesso que eu pensei em desistir, né, pensei em desistir, já... assim que eu verifiquei que estava tudo ok, né, assim, não tinha tido nenhum ferimento mais grave [...] afinal não tinha ido ali para fazer dez quilômetros, né, tinha ido para fazer mais, já que eu me propus a tal atividade. Acho que o desafio ficou maior, né, mas, realmente, não foi uma situação também confortável' (Luís).

$\mathrm{Na}$ fala do entrevistado Luís, a dor e o sofrimento após uma queda não foi suficiente para fazer com que ele desistisse, mesmo sendo ele um atleta amador e não almejar ser, um dia, um profissional da corrida de rua. 
Expressões como cansaço, desânimo e dor são bem frequentes entre os que têm em sua rotina de exercício a corrida de rua. Fica mais claro perceber esses sinais de desgaste 'corporal' tendo como ponto de partida e sustentação, aspectos biomecânicos (de ordem muscular e articular), embora não seja este nosso foco de abordagem, uma vez que muitas destas causas vão além do 'físico', abarcando esferas emocionais e também de ordem sociais. E não só na corrida de rua, mas também em outros ambientes próprios para a prática de exercícios, pois "o enfrentamento da dor, do sofrimento, do sacrifício e da privação é frequentemente encarado como algo corriqueiro e 'normal' por parte dos frequentadores de academias" (TORRI, BASSANI e VAZ, 2007, p. 266).

$\mathrm{Na}$ prática cotidiana da corrida de rua, a expressão "sacrifício" não é encarada como um "gesto de boas vindas". Não é pensando em sacrificar-se que se pratica a corrida de rua; o que se busca é uma prática prazerosa, que remeta a bons resultados, sejam esses biológicos, emocionais e/ou sociais; sendo eles agradáveis e muitas vezes visíveis, assim como descreve Vaz (2001, p. 95) sobre "a dor, antes de ser entendida como uma expressão irrenunciável da corporeidade, passa a representar um obstáculo a ser suportado, superado, ou, inclusive, tornado fonte de prazer".

Neste contexto, em que superar a dor se torna necessário para alcançar o prazer, uma das entrevistadas responde: "...nesse período eu consegui melhorar, me recuperar e consegui treinar para fazer a prova sem nenhum problema. Foi sacrificante porque correr 4 dias seguidos e... sendo a primeira experiência em uma maratona não foi uma... uma coisa fácil" (Sueli). Neste caso, a entrevistada se referia ao Desafio do Dunga ${ }^{36}$, uma sequência de quatro provas, que acontece no parque de diversões Walt Disney World, na cidade de Orlando, estado da Flórida, Estados Unidos.

As palavras dor e sacrifício, neste trabalho - entendidas como expressões resultantes da corrida de rua - nos leva, portanto a caminhos que 'parecem' se encontrar. Em muitos casos, na prática da corrida de rua, o atleta tem consciência de que será, na maioria das vezes, uma consequência previsível desta expressão corporal. Mais uma vez, os gestos técnicos advindos desta prática, remetem a um

\footnotetext{
${ }^{36}$ O Desafio do Dunga compõe uma corrida de cinco quilômetros na quinta-feira, dez quilômetros na sexta-feira, 21 quilômetros no sábado e a Maratona no domingo, somando assim aproximadamente 78 quilômetros em dias consecutivos e acumulando, desta forma, 6 medalhas de reconhecimento pelo cumprimento de todo desafio.
} 
contexto em que para se adquirir os resultados esperados por quem os pratica, 0 sacrifício e a dor terão que ser enfrentados ou vivenciados em algum momento (senão a todo instante). Mas então como explicar que a cada ano, mais pessoas se interessam por esta prática realizada em praças, parques, vias públicas (aqui entendidas como a rua)?

Como se sabe, a dor não é uma "aliada" do treinamento corporal, mas, do ponto de vista subjetivo, o inimigo a ser combatido, superado, suportado, ignorado - ou ainda, num registro mais fronteiriço, a experiência a ser glorificada, desejada, certificação de que de fato se está indo além dos limites e que, portanto, há mérito na dilaceração do próprio corpo (HANSEN; VAZ, 2004, p. 142).

Nas palavras de Hansen e Vaz (2004), ao trazerem a relação entre a dor e os resultados esperados, o papel do corpo é poder superar os momentos que diríamos como 'difíceis' e até acredito que mais que difícil: é superar o insuperável, os limites de cada um, é buscar tornar-se um super herói. Ter a certeza de que além da dor existe o mérito pelo esforço apresentado move o praticante a ir além dos seus próprios limites conhecidos, chegando em estágios de satisfação e prazer. Talvez aqui possamos remeter a outra expressão bastante conhecida na prática de exercícios, que é o 'vício bom', a partir da certeza de que a prática cotidiana (rotineira e assídua) da corrida de rua irá viciar o atleta em uma prática corporal que Ihe trará resultados positivos. Para tanto, Hansen e Vaz (2004, p. 143) justificam que: "esta submissão a privações e a uma árdua rotina de exercícios muitas vezes torna-se algo imprescindível, um 'vício"'.

Adentrando um pouco mais no significado da palavra sacrifício, Mauss e Hubert em sua obra: Sobre o Sacrifício, nos ajudam a refletir o tema, oferecendo dimensões que vão além do cotidiano dos corredores de rua. Na obra citada, os autores tomam como exemplo os sacrifícios hindu e hebraico. Para eles, mais que uma oferenda, o objeto do sacrifício: o corpo (neste caso, na corrida de rua) devia ser total ou parcialmente destruído ou consumido.

Muitos autores traduziram bem esta obra, trazendo um contexto atual para os rituais do sacrifício, escritos por Mauss e Hubert. Rigoti (2008, p. 87), por exemplo, escreveu que "o modo como o corpo estava presente nos rituais citados pelos autores não é o mesmo nos dias atuais, mas o fato é que ele ainda se constitui 
como o principal "objeto" utilizado pelo homem religioso na busca do sagrado". Santos (2011) traduziu bem a palavra Sacrifício. Ela, parafraseando a obra de Mauss e Hubert, em sua introdução afirma: "A palavra sacrifício significa cumprir um ato ou ofício sagrado. Sendo assim, o sacrifício é um mecanismo social produtor do sagrado" (SANTOS, 2011, p. 21)

Ainda na obra "Sobre o Sacrifício", uma estrutura (do sacrifício) nos chama a atenção, pois é possível pensar numa analogia com a corrida de rua, uma vez que os elementos se encaixam. Esta estrutura tem cinco etapas, sendo a primeira delas a entrada do sacrifício. O elemento seguinte é o próprio sacrificante, sendo este, aquele que oferece o sacrifício. O terceiro elemento, o sacrificador, é o mediador do sacrifício a ser ofertado. Ele é também conhecido como o Sacerdote; é aquela 'figura' com um status que the permite intermediar o sacrifício a ser realizado. $O$ quarto elemento se refere ao lugar e os instrumentos a serem utilizados no ato do sacrifício. E finalmente, o elemento: saída do sacrifício, ou seja, é o ato conclusivo do sacrifício realizado.

Para esta estrutura, Santo traduz: "os ritos sacrificiais, de um modo geral, compartilhavam a crença de que no ato de sacrificar ocorria uma união mística com a divindade. O ser que oferece o sacrifício e o próprio sacrificado participa da esfera sagrada" (SANTOS, 2011, p. 25).

Ensaiando uma relação possível entre estes cinco elementos que compõem a estrutura do sacrifício para Mauss e Hubert, poderíamos afirmar que na corrida de rua o elemento "entrada" se traduz como todo contexto que prepara o atleta amador para a realização de uma corrida: os treinos, sua alimentação/hidratação, descanso pré-treino ou pré-corrida.

O elemento entendido como o sacrificante, aqui conhecido como aquele que faz a intermediação entre aquele que sacrifica e aquilo que é sacrificado (o orientador, o mediador), é assumido como o papel do professor, do técnico, do treinador. Entende-se aqui que a este elemento é dada a confiança para fazer com que o sacrifício possa obter o melhor êxito ou os resultados esperados positivamente após o sacrifício. Muito poderíamos escrever sobre este elemento, visto ser a ele dada a competência pela construção do planejamento e pela condução dos treinos cotidianos e específicos no intuito de levar o corredor de rua a encontrar o melhor caminho para que seu objetivo seja contemplado. Como a 
intenção aqui é de realizar uma analogia sobre o tema, não iremos nos ater a discutir profundamente sobre o papel do professor/treinador e sim sua participação neste contexto de sacrifício e de corrida de rua.

Talvez seja o sacrificador o elemento principal nesta descrição. É o corredor de rua, nosso personagem protagonista neste trabalho. Completar uma corrida com distância de 5 quilômetros ou ultrapassar distâncias como 42, faz do corredor de rua uma pessoa capaz de superar seus limites, que para muitos, ainda eram desconhecidos. Não é a distância (apenas) que está posta como desafio, mas seu alcance. O quanto isso possa valer para cada um dos corredores de rua, é o quanto este 'sacrifício' valerá a pena de ser completado. "As ocasiões de sacrificar são inúmeras e os efeitos desejados muito diferentes, e a multiplicidade dos fins implica a dos meios" (MAUSS e HUBERT, 2013, p. 21). Cada atleta tem uma expectativa diferente sobre onde quer chegar e o quanto ele irá investir para alcançar os resultados esperados (não apenas financeiramente). Neste caso, mesmo tendo na estrutura do sacrifício o papel claro do 'Sacrificante' (ou o professor/técnico), muitos corredores de rua se aventuram em correr e buscar o sucesso de seus objetivos sem a participação deste elemento.

$\mathrm{O}$ ato de correr ou a prática da corrida de rua, nesta estrutura, assume 0 quarto elemento, entendida aqui como o lugar e instrumentos. Para Mauss e Hubert (2013, p 26) "há continuidade entre as formas do sacrifício. Elas são ao mesmo tempo muito diversas e muito semelhantes". Por isso correr 5 quilômetros ou uma ultramaratona $^{37}$, não faz do atleta ultramaratonista um corredor de rua com maior importância ao realizar o sacrifício, pois a estrutura é a mesma, diferenciando apenas a forma do sacrifício a ser realizado. Para uma pessoa sedentária que inicia um 'programa' de corrida de rua e almeja um dia correr seus primeiros quilômetros, exige dela e do professor/treinador tantos cuidados necessários para se alcançar seu objetivo quanto os teria um atleta que planeja, um dia, correr uma Maratona.

Destacamos ainda elementos mais evidentes no cotidiano das corridas, como o calçado a ser utilizado e a importância que cada atleta se atém com este item. Vestimentas em geral e acessórios como aparelho para ouvir suas músicas

\footnotetext{
${ }^{37}$ Uma Ultramaratona compreende uma corrida que tem sua distância maior que $42.195 \mathrm{~m}$ (distância da Maratona). Há ultramaratonas de 48 horas, onde o atleta vencedor chegou a 473 quilômetros de distância, é o caso do grego Yiannis Kouros, no ano de 2008.
} 
preferidas (enquanto se corre), relógios para orientar o tempo e a distância a ser percorrida.

Chegamos então no estágio final desta estrutura: a saída do sacrifício. O dia em que a meta prevista será realizada. Em geral a própria corrida de rua a ser realizada pode ser traduzida como este dia. A maior parte dos corredores de rua que buscam um planejamento e acompanhamento de seus treinos almeja completar uma corrida específica. Concluir esta corrida seria a conclusão do sacrifício e também o 'fechamento' de um ciclo de treinamentos especificamente pensados para este fim. A conclusão deste 'ciclo' toma assim o papel de saída ou conclusão, em que o corredor de rua, após ter completado seu planejamento previsto, finalizou esta etapa.

Com isto percebemos a importância do tema sacrifício na rotina dos corredores de rua. Pouco abordado nos treinamentos e nas próprias corridas, 0 sacrifício se faz presente a partir do momento em que cabe ao corredor de rua superar situações que vão contra seus objetivos: cansaço, dor e até lesões tornam os caminhos a serem percorridos por estes praticantes um verdadeiro sacrifício, mas possíveis de serem superados. Assim também as superações destes sacrifícios tendem a tornar seus praticantes ainda mais fortes e prontos para iniciarem novos ciclos. 


\section{CAPÍTULO III - APROXIMANDO O TEMA RITUAL COM A EDUCAÇÃO FÍSICA E A CORRIDA DE RUA}

No universo das corridas, considerando já a partir de sua preparação, a corrida de rua em si pode ser considerada como um processo ritual. $O$ aspecto extraordinário ou liminar da corrida de rua se manifesta antes mesmo da própria corrida, com os treinos e exercícios preparatórios, sendo eles, geralmente, realizados em grupos. Este capítulo tem a intenção de discutir, com base nos conceitos de liminaridade de Turner e de ritual, trabalhado a partir de Maus e Hubert (2013), as corridas de rua.

3.1. "E assim eu corro mais" (fala de um atleta amador, 2015).

Nesta etapa trataremos de temas como Liminaridade e Performance (temas amplamente estudados por Victor Turner) e ainda dos Ritos de Passagem, sendo seu precursor o antropólogo francês, Arnold Van Gennep. Estas linhas de pensamento estão imbricadas entre si e, portanto trataremos nesta relação o ritual e a corrida de rua.

Momentos liminares, únicos, específicos, marcantes ocorrem em nosso cotidiano, bem como no cotidiano dos atletas amadores nas corridas de rua. Situações que marcam profundamente as corridas, como a largada de uma nova prova; completar uma corrida pela primeira vez numa nova distância (tendo corrido um dia 5 quilômetros e passar a correr 10); terminar uma corrida com um tempo desejado ou até abaixo; correr em homenagem a alguém ou por alguma causa são momentos liminares que ficam marcados neste contexto, bem como correr com os pés descalços.

$\mathrm{Na}$ Volta Internacional da Pampulha ${ }^{38}$, em 2015, registramos nos quilômetros finais, um corredor com os pés descalços. Coincidência ou não, foi o único que conseguimos identificar ao longo dos 18 quilômetros de toda corrida. Se correr com tênis pode causar algumas bolhas nos pés, o que dizer de quem corre

\footnotetext{
${ }^{38}$ A corrida de rua chamada Volta Internacional da Pampulha ocorre desde 1999, onde seu percurso é uma volta inteira ao redor da Lagoa da Pampulha, localizada em Belo Horizonte, MG. São 17.800 metros e nos fazemos presentes desde a edição de 2008
} 
sem nenhuma proteção para os pés. É uma questão de adaptação. Talvez nem todos consigam este feito, mas com alguma insistência e técnica, seja possível se adaptar.

Na obra citada no capítulo anterior (Nascidos para Correr), os indígenas da tribo Tarahumara, que corriam, desde seus ancestrais, com pés descalços, corriam com prazer e não para competir. No entanto, ao desenvolver a habilidade de correr com os pés no chão, eles não se machucavam com lesões comuns entre os corredores de rua, pois desenvolveram a postura natural de correr. E correr por alegria e não por competição.

Esse era o verdadeiro segredo dos tarahumaras: eles nunca esqueciam como era gostar de correr. Tinham em mente o fato de que a corrida foi a primeira arte que o ser humano dominou, o nosso ato original de criação inspirada. Ao mesmo tempo que desenhávamos imagens em cavernas e tirávamos sons de troncos ocos, também aperfeiçoávamos a técnica de ajustar a respiração, a mente e os músculos, buscando uma ágil autopropulsão sobre superfícies íngremes. E, quando os nossos ancestrais finalmente fizeram os primeiros registros nas cavernas, o que eles retratavam? Um rápido raio, um ataque vigoroso - veja só, o Home Corredor (MCDOUGALL, 2010, p. 127).

A imagem revela o corredor em contato com o chão no último quilômetro da corrida em Belo Horizonte, em dezembro de 2015. Acreditamos sim que este momento seja de liminaridade, pois como dizia Duarte e Menezes "a liminaridade é uma forma expressiva que os atos culturais assumem, ela possibilita a criatividade e, por isso mesmo, também a transforma" (DUARTE e MENEZES, 2005, p. 47).

Registramos, ao longo desta edição da Volta da Pampulha (2015), dezenas de imagens e apenas numa delas, que também registra a distância que estávamos no momento da imagem (quilômetro 17) este atleta amador encontrava-se descalço (FOTO 09).

Quanto à performance, este termo, muito falado nas corridas e nos demais esportes, geralmente se refere ao resultado obtido durante uma corrida (ou numa competição), em que o atleta está voltado para o alto desempenho. No entanto, aqui trataremos com outro olhar a palavra performance, percebendo nuanças como correr descalço ou correr vestido com algum personagem folclórico ou um super herói. Trazemos a seguir ilustrações registradas em 2015, durante a Volta 
Internacional da Pampulha, alusivas a essas observações, que dão à corrida um caráter mais lúdico e menos competitivo, ao menos para quem desta forma se dispõe a correr.

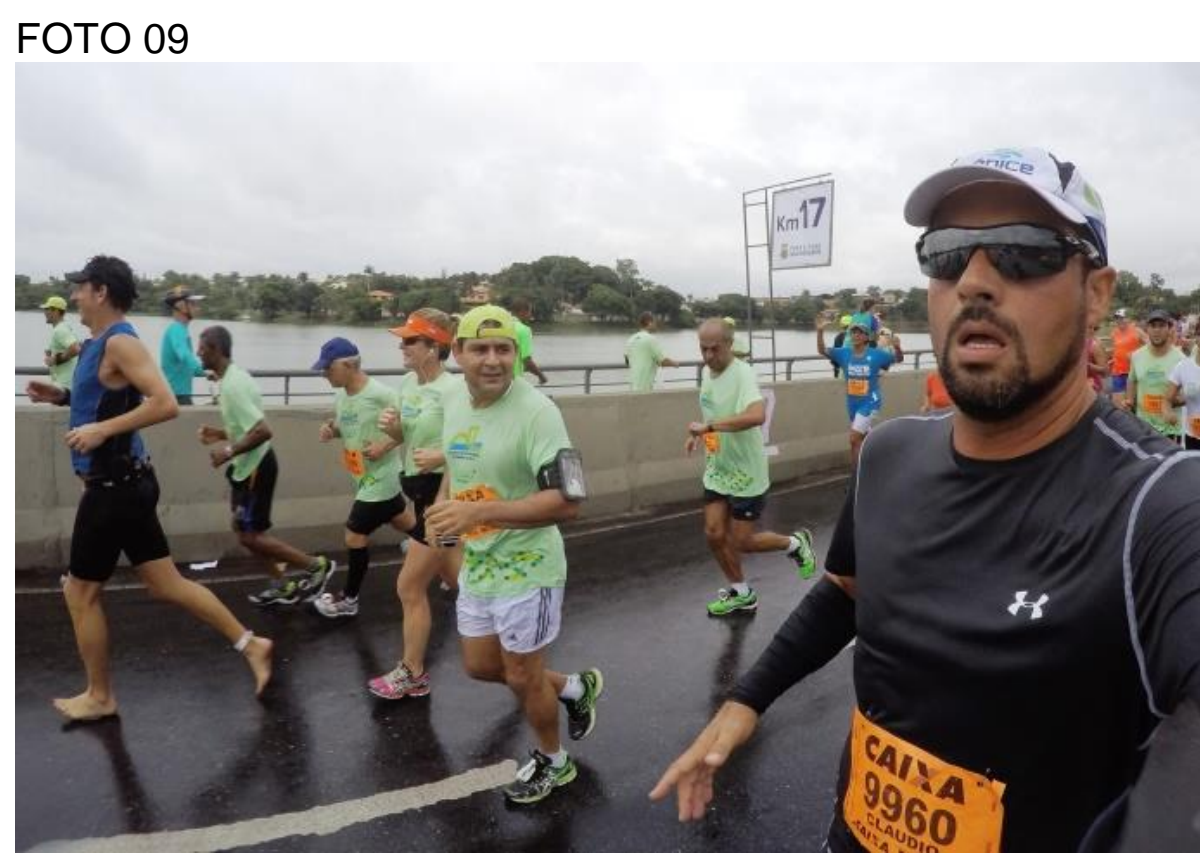

Fonte: ARRUDA (2015). Arquivo de pesquisa.

Não percebemos competitividade entre os atletas que se dispõem a correr vestidos de personagens ou super-heróis. Eles estão, na maioria do tempo, interagindo com os demais, brincando, sorrindo, dispostos a serem fotografados e sempre bem humorados.

Nas imagens 10, 11 e 12 o destaque também se deve pela disposição dos atletas em se preparar para correr com roupas fora do habitual da corrida. Recomenda-se correr com roupas leves, que facilitem a transpiração e a liberdade do movimento corporal. Enquanto recomendamos que se corra com vestuário que facilitem o resfriamento do corpo, percebemos nestes atletas uma característica diferenciada. 


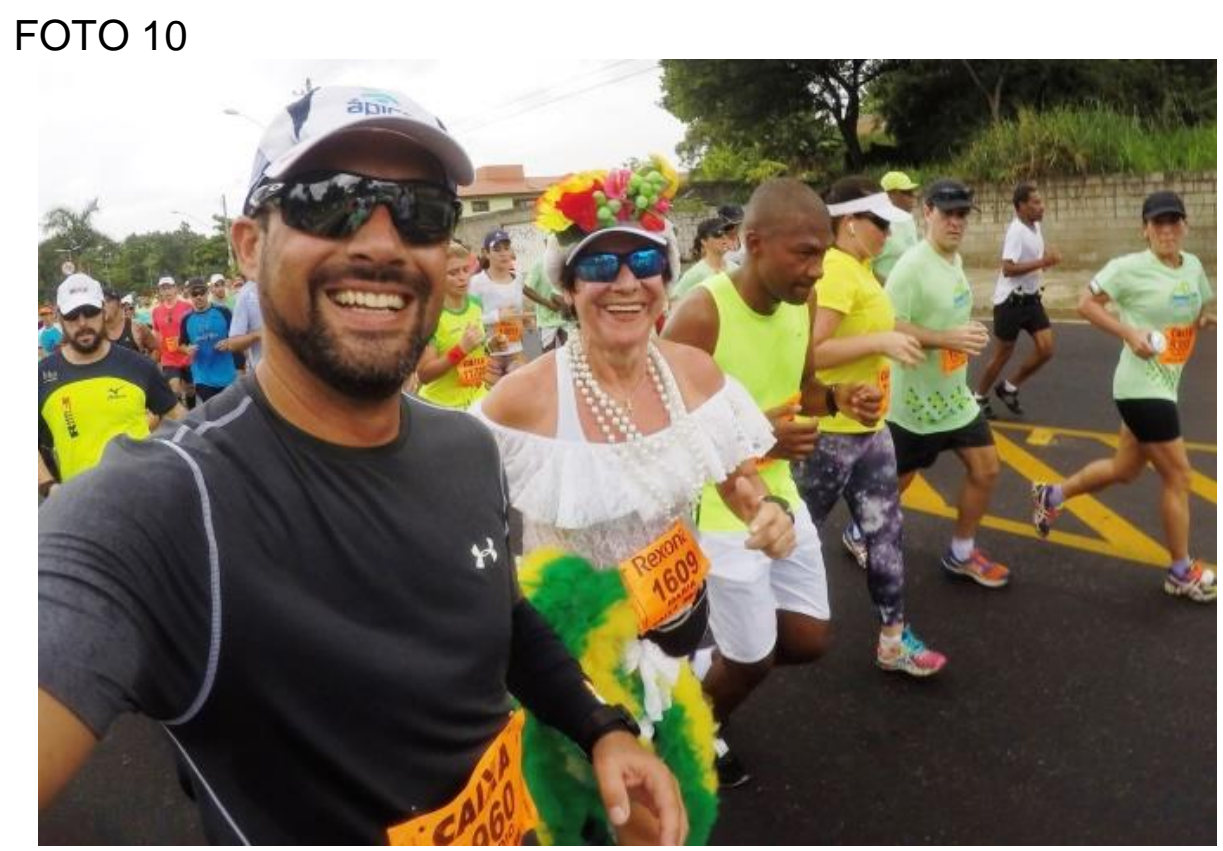

Fonte: ARRUDA (2015). Arquivo de pesquisa.

Ainda mais o caso do 'batman', com roupas escuras, máscara e capa. A alegria de correr e o aspecto não competitivo se apresentam com maior clareza.

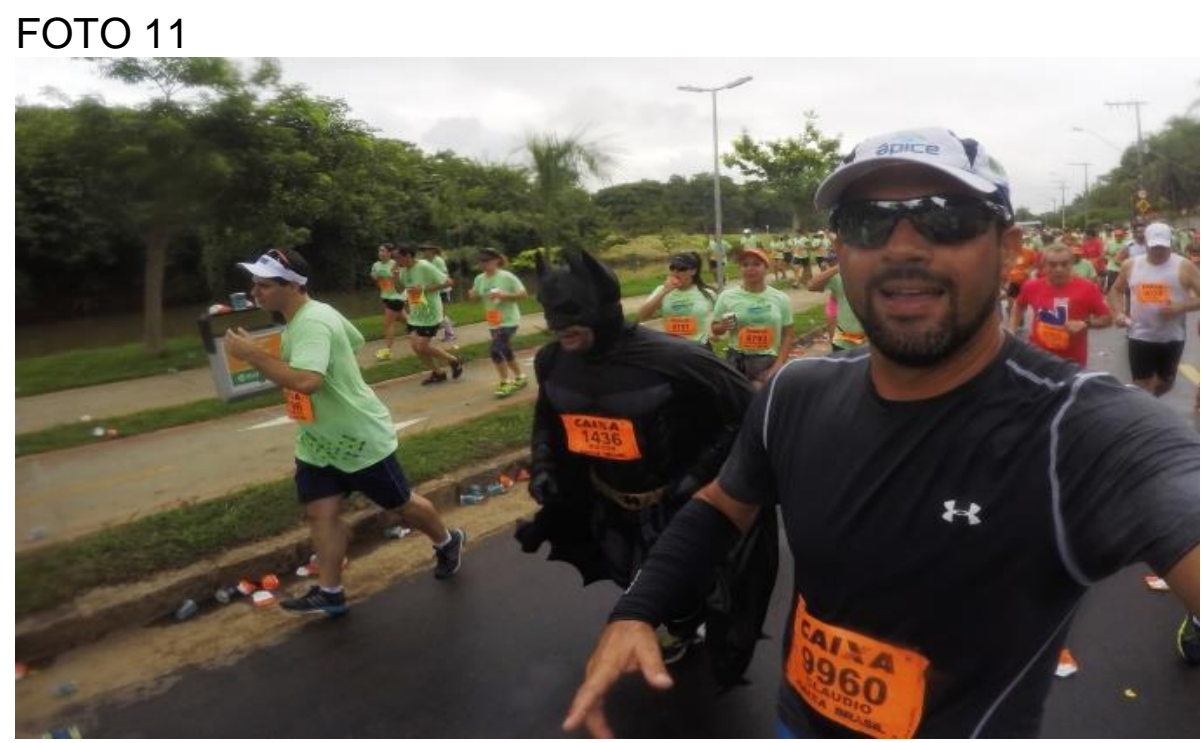

Fonte: ARRUDA (2015). Arquivo de pesquisa. 


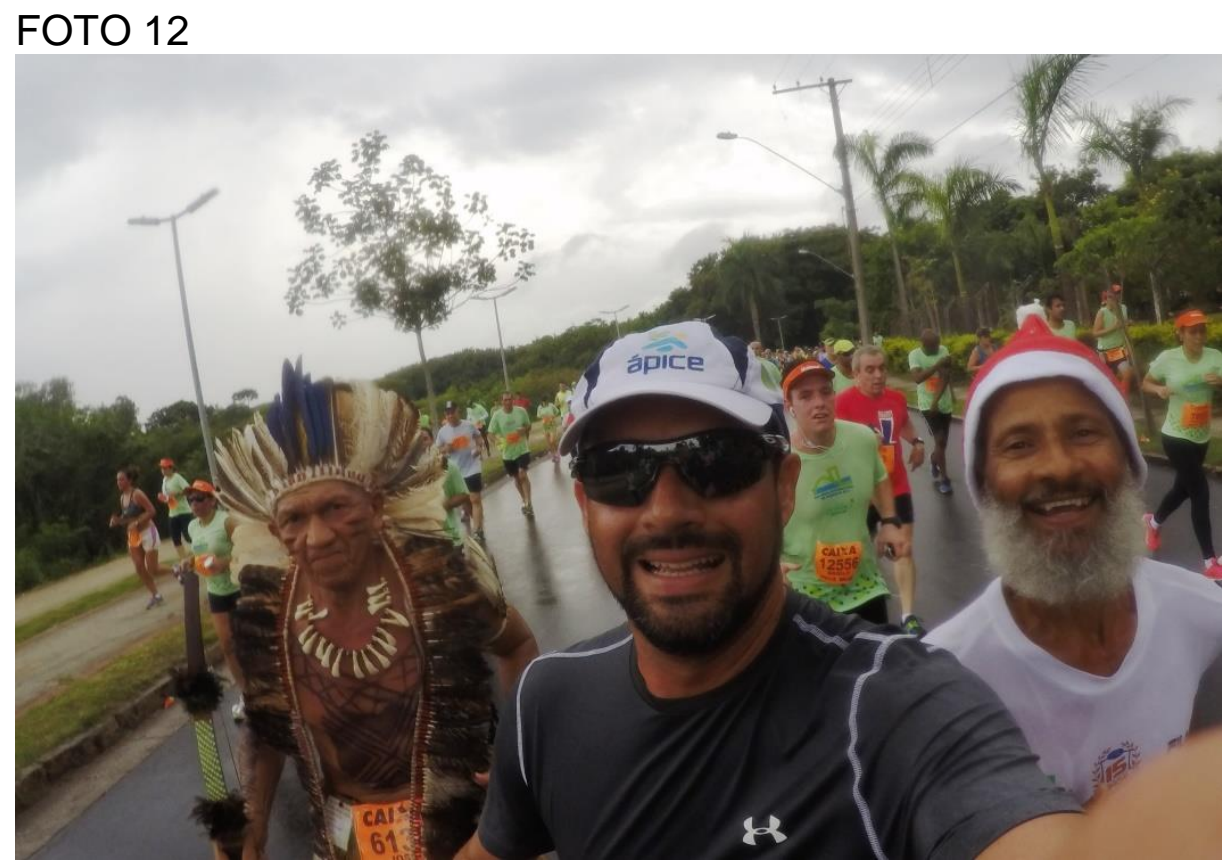

Fonte: ARRUDA (2015). Arquivo de pesquisa.

A alegria de percorrer diversos quilômetros caracterizado, fantasiado, muitas vezes revela uma homenagem ou reverência a algo ou alguém. Sair dos parâmetros tradicionais faz destes atletas, inscritos da mesma forma que outros atletas, na mesma corrida, diferentes dos demais enquanto propósito, mas são igualmente reconhecidos como atletas amadores.

Assim se revela o caráter lúdico da corrida, o despropósito com o tempo, com a performance física e o propósito pela performance citada amplamente por Gennep (2011) Duarte e Meneses (2005), Cavalcanti (2012), Costa (2013) dentre outros. Desapegar-se de ideias como ser mais rápido ou chegar antes de demais é algo ainda a ser superado pela grande parcela dos atletas, mesmo amadores.

Por diversas vezes, percebemos que a competição se sobressai nas corridas de rua, entre amigos. No entanto é importante esclarecer que não somos discordantes da competição, que até julgamos importante, motivadora e por vezes saudável. Registramos apenas que parece haver, entre aqueles que de forma distinta dos demais, se caracterizam de personagens, um descomedimento com a competição, deixando sobressair o lado hedônico e muitas vezes até mais saudável da corrida, pois somos amadores e não profissionais da corrida. 


\subsection{Sobre os ritos constituindo o ritual da Corrida de Rua}

A repetição cíclica, criando rotinas que organizam com frequência determinados acontecimentos faz parte dos rituais, como nas corridas, quando o atleta repete certos gestos (corporais ou de outra natureza) que o trarão resultados esperados, como sua alimentação ou como sua preparação momentos antes de uma corrida (PEIRANO, 2003).

"De maneira geral, o que Turner destaca [...] é que o ato ritual é uma manifestação povoada de simbologias e representações que podem estar associadas a uma cosmogonia ou a aspectos diretamente ligados ao cotidiano da sociedade" (COSTA, 2013, p. 52).

Fenômenos culturais e esportivos se transformaram numa espécie de produto de consumo, envolvidos pela sedução constantemente insistente da "indústria cultural" (incluindo aí a indústria desportiva). Nestas sociedades, os atores sociais desfrutam do livre arbítrio para decidirem, por si mesmos, a participação ou não em determinados tipos de atividades esportivas.

Uma corredora de rua, com 56 anos de idade, por nós entrevistada em 2016, sobre que tipo de cuidado ela toma antes de correr, respondeu:

"Deixo o tênis, olho se o relógio está carregado, se não está eu ponho para carregar, se não carregar eu vou sem. Então eu não tenho muita frescura não. Mas algumas coisas assim, do ritual da corrida que eu preciso de um boné para proteger, de um protetor solar... E assim, roupa não tenho muito isso. Eu gosto da bermuda de compressão, mas ela... pra corridas mais distantes, assim; mas meia maratona na para cima. Porque ela realmente protege, eu acho que ela não deixa a perna ficar batendo uma na outra. Mas assim, no geral, para treino, para outras corridas, eu geralmente não tenho muita frescura não. Pego uma roupa e vou embora" (Maurine).

A preparação de um corredor para uma corrida de rua já é um evento relevante, considerando aqui a preparação como uso de materiais e instrumentos como vestimentas, calçados e demais assessórios, bem como os treinos 
preparatórios. As assessorias esportivas ${ }^{39}$ ou academias de ginástica oferecem o serviço de treinamento em grupo e/ou individual para a corrida de rua. Pensamos que diversos são os motivos que fazem um sujeito 'treinar' ou se preparar para sua participação na corrida de rua, fazendo parte de um 'grupo de corrida'. O aspecto coletivo é aparentemente um motivo que faz com que ocorra este interesse.

Para Cruz (2013) os rituais tornam o esporte mais humanos, não apenas com aspectos competitivos. Para ele:

"el deporte construye una serie de creencias, sentimientos y comportamientos que se vivencian en forma de ritual" (CRUZ, 2013, p. 318). Para ele, o esporte é sinônimo de uma boa conduta humana, oferecendo respostas diversas de interpretação na vida: "ensalzan el aspecto humano del deporte que, por su total implicación corporal, ritual y espiritual, está llamado a desempeñar cada vez más un profundo rol de garantia humanística" (CRUZ, 2013, 319).

Nessas atividades, o destaque se volta para o agente, que neste trabalho se revela como o corredor de rua, sendo algo individualizado (mesmo quando as atividades acontecem em equipe, citando aqui as assessorias esportivas); e com a grande quantidade de corridas ao longo do ano ofertadas e a diversidade de materiais esportivos, se torna possível, de acordo com o "gosto" e o interesse particular, a seleção do tipo de atividade ou estilo singular preferido pelo respectivo sujeito. Corridas de 5 quilômetros ou até uma Maratona, corridas em trilha (também conhecida como 'corrida de montanha'), corridas de revezamento e ainda ultramaratonas são alguns exemplos da ampla diversidade do tipo de corrida de rua praticada nos dias atuais.

Em Brasília, duas ultramaratonas fazem parte do calendário das corridas: citada no capítulo anterior, a mais antiga delas é Volta do Lago, que em 2016 completa 13 anos de história. Além da categoria revezamento há as categorias solo (individual) com as distâncias de 60 ou 100 quilômetros.

Outra ultramaratona que vem ganhando espaço é a Corrida 24 horas de Brasília. Acontece há 4 anos e seu percurso é de apenas 4 quilômetros no Parque da Cidade. As categorias podem ser por equipes (com qualquer número de atletas)

\footnotetext{
${ }^{39}$ Empresas do ramo da Educação Física, geralmente voltadas para o treinamento de exercícios ao ar livre, como corrida, ciclismo, exercícios funcionais, dentre outros.
} 
ou na categoria solo - sendo esta de 12 horas ou 24 horas. O atual campeão da prova percorreu, em 2015, pouco mais de 200 quilômetros em 24 horas.

Duarte e Menezes (2005, p. 43) diriam também que a corrida de rua se tornou um fenômeno 'liminar', pois diversos podem ser os motivos que fazem o corredor de rua participar de uma determinada corrida, como uma ultramaratona de 24 horas. As motivações empregadas numa nova corrida podem torna-la um momento liminar, ao passo que as expectativas a ela agregada tornam o sujeito repleto de euforia ao participar. Uma nova distância, um lugar diferente, uma corrida com um grupo de amigos (revezamento ou individual), que envolva também uma viagem; nas corridas de rua é muito comum que grupos de amigos viajem para outras cidades ou para outros países, em busca de 'novas paisagens'. Para tal, Duarte e Menezes diz que "é uma liminaridade que consegue romper com a 'ordem natural' da sociedade e transformar as performances e os ritos em eventos significativos para as sociedades em questão" (DUARTE e MENEZES, 2005, p. 43).

Sobre o estado liminar, Costa ainda afirma:

"o estado liminar suscita esta união ou sentimento de igualdade entre os indivíduos, pois neste instante as vaidades relacionadas aos status sociais deixam de existir uma vez que a própria noção de status não se aplica àquele momento" (COSTA, 2013, p. 53)

A fim de discutirmos a questão da liminaridade, destacamos aqui 3 (três momentos) que ao longo dos registros feitos de campo realizados durante a Corrida de Reis. O primeiro deles foi a chegada e a preparação dos corredores. Chegamos ao local da corrida, o Estádio Mané Garrincha, uma hora antes da previsão da largada. Em geral os atletas amadores e profissionais chegam cedo, afim de melhor se prepararem para a corrida. Um momento de aquecimento e alongamento, além de eventuais encontros com amigos antes da corrida são situações bem comuns.

$\mathrm{Na}$ imagem a seguir (FOTO 13) é possível descrever vários momentos peculiares dos instantes antes da corrida. Enquanto alguns atletas realizam um alongamento em preparação ao evento, outro se curva para poder fazer a amarração de seu cadarço e do chip que irá registrar sua participação e seu tempo após a corrida. Enquanto isso, vemos ainda um atleta fixando em sua camisa o número de peito, que o identifica dentre os demais em meio aos milhares de corredores. 
Citando Turner, através das performances, e particularmente, da corrida de rua como performance, é possível examinar a experiência vivida do ator como uma experiência singular da liminaridade, na qual afloram os mais diversos tipos de sentimentos.

\footnotetext{
"O pesquisador deve, portanto, desenvolver a capacidade de apreender o que os nativos estão indicando como sendo único, excepcional, crítico, diferente [...] a pesquisa precisa ser etnográfica - apreendida pelo pesquisador em campo junto ao grupo que ele observa" (PEIRANO, 2003, p. 06).
}

Vale aqui ressaltar que o termo 'performance', em Turner, se distingue da expressão 'performance', também utilizada no treinamento desportivo. No segundo caso, e também associado à corrida de rua, a performance é tratada frequentemente como performance física ou também alta performance, sendo direcionado para o alto rendimento físico, na busca do melhor resultado em competições, sendo também utilizado entre atletas amadores. A figura a seguir ajuda a evidenciar a liminaridade da manifestação, bem como a sua constituição como um ritual.

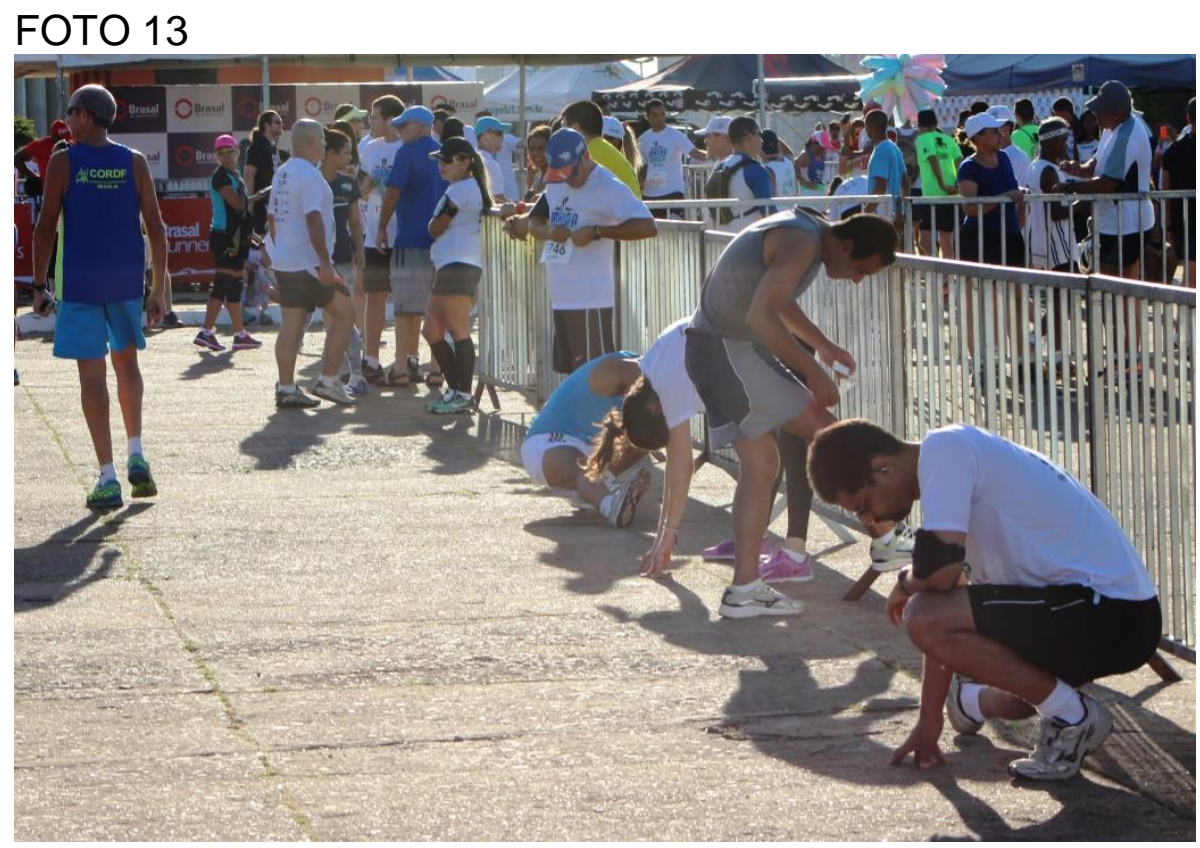

Fonte: ARRUDA (2016). Arquivo de pesquisa.

De acordo com a Figura acima, percebemos alguns corredores realizando um momento de reflexão antes da corrida. $O$ fato de alguns deles estarem em concentração, como uma espécie de instante de introjeção pessoal, em que além 
dos cuidados com questões como o calçado (amarração do tênis), hidratação, há uma preocupação com o sentido daquilo que estão fazendo, seus objetivos com a corrida, tanto que alguns desses corredores fazem o sinal da cruz, tão logo a corrida se inicia. Todos esses elementos podem ser entendidos como ritos, que se inserem no ritual da corrida.

Particularmente na Corrida de Reis, nos últimos anos, quando houve um acréscimo importante no número de inscritos, no momento da largada houve uma divisão de posicionamento entre os inscritos nos 10 quilômetros e nos 6 quilômetros $^{40}$. Além disso, o fato de ser corrida dos Reis Magos também compreende um valor simbólico importante. Falando nesse aspecto, duas grandes e tradicionais corridas brasileiras. Uma que é realizada no fim do ano e representa um período de realização por algo que já ocorreu, que é a Corrida de São Silvestre, realizada em São Paulo, capital, e a outra, a Corrida de Reis, que ocorre em Brasília/DF, são corridas que estão de acordo com o calendário de santos católicos e que se referem ao fim ou início de um período ou tempo cronológico, mas em que os corredores depositam expectativas em realizações pessoais, profissionais. Esse tipo de organização facilita o posicionamento dos corredores e possibilita que haja maior organização geral no mento da largada, em corridas com número elevado de participantes.

Nas imagens seguintes registramos os dois momentos desta largada, a fim de ilustrar os momentos distintos para as duas distâncias, embora o percurso tenha sido o mesmo, ao longo dos primeiros 3 (três) quilômetros, sendo este o ponto de retorno da corrida de 6 quilômetros. A foto 14 revela o momento e os primeiros participantes na distância de 10 quilômetros, enquanto que numa das fotos no apêndice deste trabalho é possível verificar os participantes posicionados para largarem na distância de 6 quilômetros, cerca de 500m atrás ${ }^{41}$.

\footnotetext{
${ }^{40}$ Tradicionalmente a corrida de reis em Brasília oferece aos participantes duas distâncias a serem percorridas, afim de aumentar o número de participantes;

${ }_{41}$ Importante esclarecer que geralmente as largadas nas corridas com distâncias de $5 \mathrm{~km}$ e $10 \mathrm{~km}$ (mais comuns entre as corridas), a largada é realizada num mesmo momento, sem distinção alguma. No entanto, na Corrida de Reis, por ter um grande número de inscritos, as largadas são feitas em locais e momentos distintos.
} 


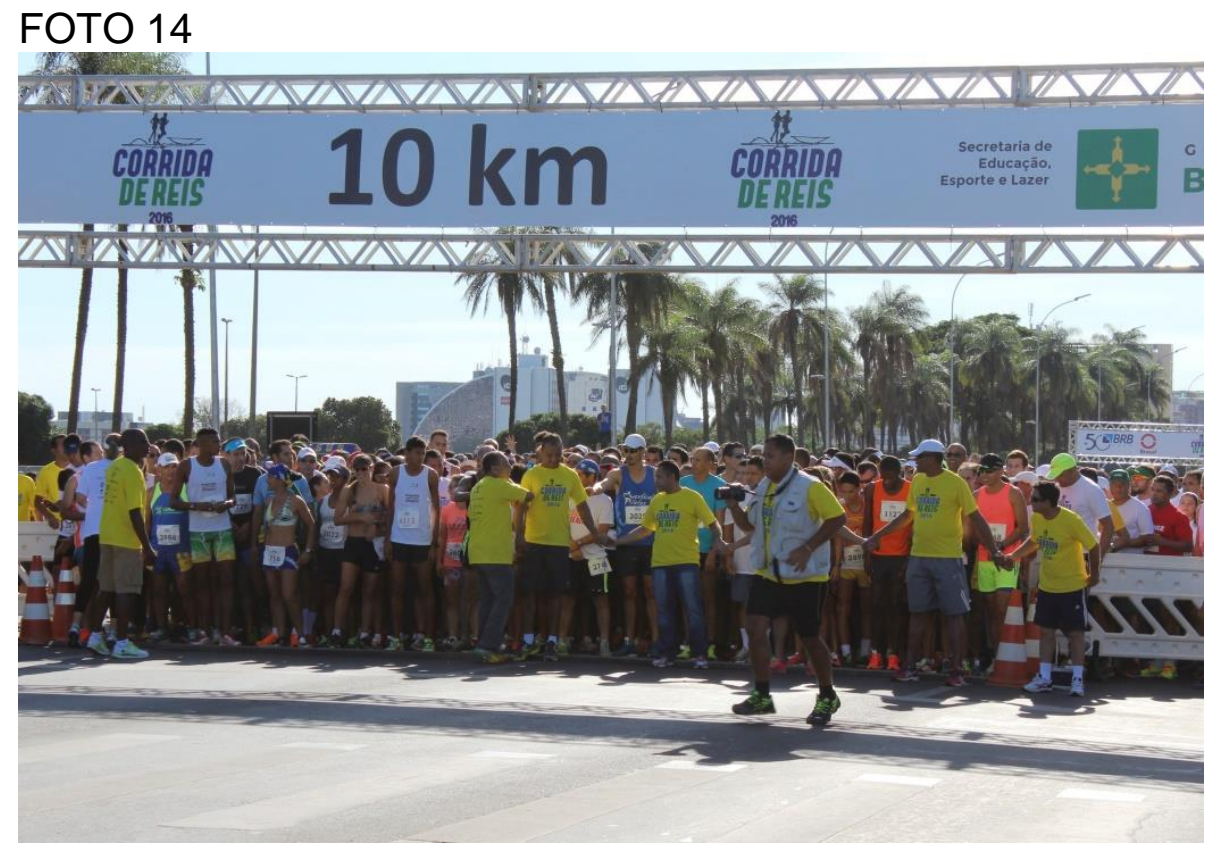

Fonte: ARRUDA (2016). Arquivo de pesquisa.

Por fim, registramos o momento após a chegada dos atletas, o momento que é entregue o reconhecimento da conclusão da corrida, o símbolo que é guardado por muitos e posto em local de destaque em suas casas, a medalha. Um ítem indispensável, guardado para ser entregue a apenas aqueles que finalizarem a corrida, como gesto a ser celebrado pelo esforço da finalização do percurso, do desafio, da superação.

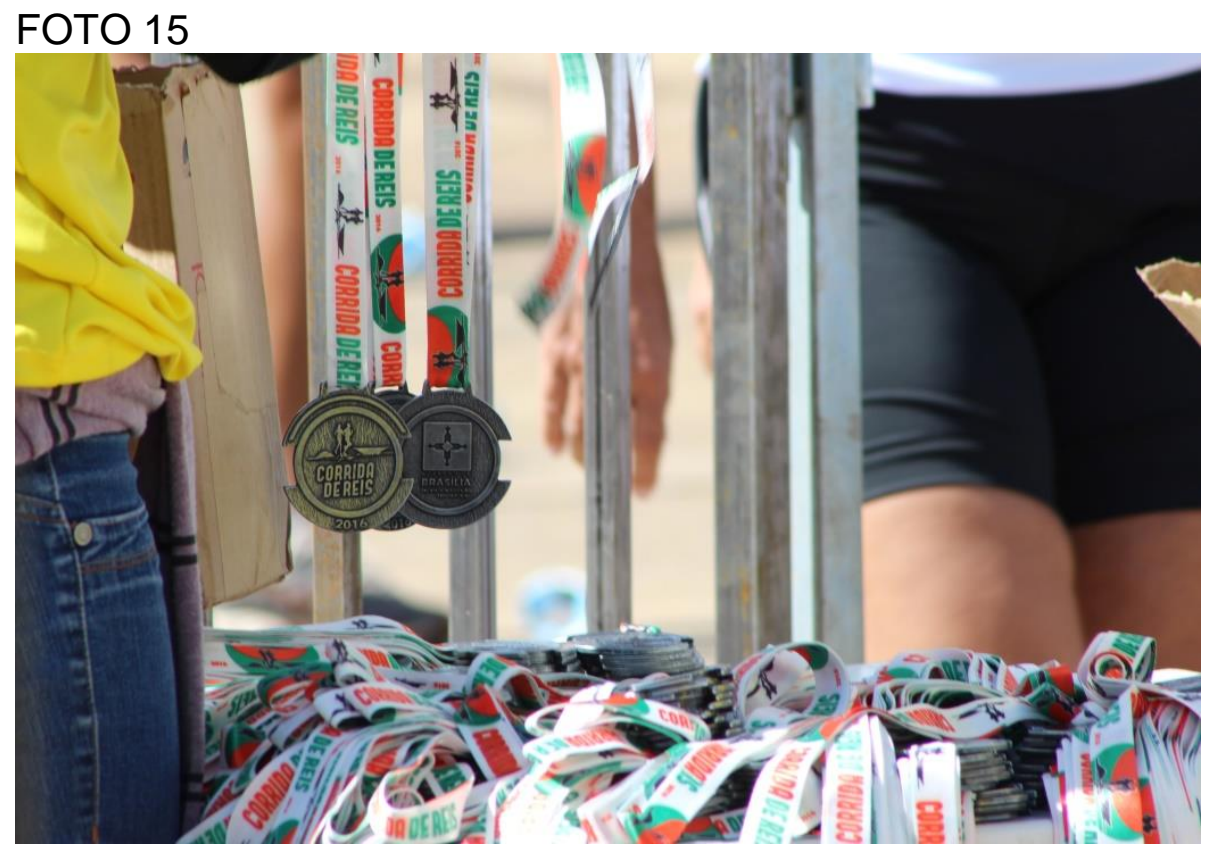

Fonte: ARRUDA (2016). Arquivo de pesquisa. 
E assim vivenciamos este dia com um olhar de pesquisador, atento às nuanças dos gestos e símbolos vivenciados pelos corredores desde sua chegada ao local da largada (conhecida também à arena da corrida), seus gestos e rituais em preparação à corrida e algumas percepções fundamentais para poder revelar alguns dos passos vivenciados pelos atletas amadores em função de uma corrida ${ }^{42}$.

Então, ritual, é uma manifestação religiosa ou ligada a certo grau de sacralização - no sentido amplo do termo - onde por meio de representações simbólicas suscita-se um estado liminar dos indivíduos, o que provoca uma reelaboração simbólica do espaço e tempo, que são relativizados (COSTA, 2013, p. 54).

Ao citar Turner, Costa nos faz refletir um sentido ainda mais especial sobre 0 momento liminar em que os corredores de rua certamente vivenciam em seu cotidiano de corridas. Para ele, o momento liminar acontece quando o corredor está 'despido' de suas indumentárias sociais. "Os indivíduos envolvidos no ritual têm uma forte tendência a desenvolver um sentido de grupo muito forte. O estado liminar suscita esta união ou sentimento de igualdade entre os indivíduos" (COSTA, 2013, p. 53).

\subsection{Ritos de Passagem}

Situação muito comum entre os corredores de rua é a mudança de objetivo ao longo das preparações para as corridas; mudanças estas associadas à sua evolução durante as preparações das corridas. Uma pessoa que apenas caminha e passa a querer correr; um corredor de 10 quilômetros que agora pretende se preparar para uma meia maratona ou até mesmo uma maratona, entre outros exemplos. Poderíamos atribuir a estas circunstâncias o que Gennep chamou de 'ritos de passagem'.

As transições ou as passagens nos rituais, como "gravidez e o parto, períodos de iniciação, noivados e casamentos, funerais, assim como mudanças de

\footnotetext{
${ }^{42}$ No entanto não trataremos, neste trabalho, o escopo relacionado a questões fisiológicas, anatômicas ou de rendimento e desempenho físico.
} 
estação ou fases da lua, plantio e colheita, ordenações e posses de novos cargos" (PEIRANO, 2003, p. 11), são alguns dos rituais de passagem.

Deixar para trás uma distância menor que se percorria como cotidiano (separação), destinar-se a se preparar para um novo desafio, ainda mais difícil de ser superado (margem) e poder sentir-se pronto para correr uma nova distância, como uma maratona ou até uma ultramaratona (agregação), são sem dúvidas momentos liminares na vida de um corredor de rua. No entanto Gennep (2011, p. 42) acrescenta: "na prática estamos longe de encontrar a equivalência dos três grupos, quer no que diz respeito à importância deles, quer no grau de elaboração que apresentam".

Propriamente sobre o ritual, Bittencourt et al. (2006) fez um breve apanhado dos autores clássicos que discutem o tema, como Claude Riviére (1997), citando:

\begin{abstract}
"Rituais são cíclicos e exercem três principais funções: a) introduzir um elemento separado do conjunto social do grupo, abrindo ao integrado a participação na identidade coletiva, como sugere os inúmeros ritos de iniciação e de passagem que conformam a vida social; b) resolver momentos de crise ao fazer reencontrar num todo harmonioso, as partes conflitantes ou elementos em desencaixe e; c) manter a estrutura social através de eventos cíclicos que simbolizem a coesão social, o sentimento de pertença e configure as identidades individuais e coletivas". (BITTENCOURT et al., 2006, pg. 25).
\end{abstract}

Em se tratando de ritual, Mariza Peirano ${ }^{43}$ muito escreveu sobre o tema, sendo também uma referência a ser considerada. Para ela, "em qualquer tempo ou lugar, a vida social é sempre marcada por rituais [...] evitamos uma definição rígida e absoluta do ritual. A compreensão do que é um ritual não pode ser antecipada" (PEIRANO, 2003, p. 03).

E assim sua afirmação contribui para ratificarmos a relação existente entre a corrida de rua e seus rituais, pois a natureza dos rituais não está em questão, tendo em vista que "eles podem ser profanos, religiosos, festivos, formais, informais ou até simples ou elaborados" (PEIRANO, 2003, p. 06).

Para um dos entrevistados, esta rotina também se dá ao se preparar para as corridas ao longo do ano, quando afirma:

\footnotetext{
${ }^{43}$ Socióloga, formada pela Universidade Federal do Rio de Janeiro (UFRJ), em 1970.
} 
"Então uma vez por semana nós temos a rotina de fazer as sessões, sessões de fisioterapia para soltar a musculatura, para verificar no treino da semana qual foi o grupo muscular que ficou mais comprometido, né, ah, tem algum ponto de tensão, tem algum ponto da musculatura que não está sentindo a vontade, que esteja dolorido, tudo é avaliado nessa sessão. Então, de acordo com esse diagnóstico é feita a manipulação muscular, né, para fazer liberação mio facial, né. Então isso também é outro cuidado que eu procuro tomar" (Luis).

Se para Bittencourt et al. os rituais são cíclicos, é comum que os atletas, ao serem perguntados por suas rotinas afim de melhorar seu rendimento ou evitar lesões relatem sobre os cuidados que eles tomam, como nos relata outra entrevistada:

\begin{abstract}
"Ter um tênis que é adaptado a minha pisada também faz toda diferença, porque você chega... do treino, você está inteiro, né? O tênis para a sua pisada é ideal. Mas fora essa questão desses... auxiliares da corrida, o que faz muita diferença para mim no treinamento é a questão... de você ter uma boa noite de sono no dia anterior... então assim, o sono implica diretamente no seu rendimento, e a questão da alimentação, então assim, a alimentação e sono são fundamentais" (Sueli).
\end{abstract}

É na fala da entrevistada, de nome fictício Sueli, que percebemos alguns rituais que se repetem, trazendo um contexto cíclico para os fatos. Ter o tênis adequado para sua pisada e assim concluir o treino sem maiores dores ou até lesões. E a entrevistada vai além, sendo questionada sobre que tipo de cuidados ela tem para que a corrida ou os treinos tenha um bom resultado. Para ela, alimentação e descanso trazem benefícios.

De fato, os pilares do treinamento são estímulo e descanso. Após um treino, seja ele longo ou curto, de baixa ou alta intensidade, é fundamental que haja repouso, para que o corpo possa absorver os benefícios do treino realizado.

E ainda quando ela se refere ao tênis certo, afirmamos que há uma relação direta entre o tipo de pisada que cada pessoa tem e o modelo de tênis mais adequado especificamente para esta pisada. Se a pisada é pronada, supinada ou neutra, a indústria de calçados para o mundo esportivo fabrica o tênis adequado para cada uma delas, no intuito de levar ao atleta o maior conforto possível, longe de lesões. E o ato de observar tais costumes com frequência e rotinização, ao longo da 
jornada de um corredor de rua, implica um sistema ritual, ao passo que costumamos repetir as mesmas ações em prol de resultados satisfatórios.

Para Pimentel (2008), o ritual exprimiria, sobretudo, sua condição cíclica, repetitiva, de retorno a si mesmo. Essa característica do rito na sociedade contemporânea permitiria um sentimento de segurança (PIMENTEL, 2008, p. 27). E é justamente esta uma das principais características relatadas pelos corredores, o cuidado contínuo, cíclico, rotineiro em torno de sua preparação e cuidado durante as corridas. 


\section{CONSIDERAÇÕES FINAIS: APROXIMANDO-SE DA LINHA DE CHEGADA}

E tendo percorrido alguns 'quilômetros' em busca do conhecimento e da reflexão sobre a corrida de rua, seus rituais e sacrifícios ao longo desta jornada, nos aproximamos da tão esperada 'linha de chegada'.

Como toda corrida tem seu início, meio e seu fim, também este trabalho se concluirá, no entanto muito distante de ser o final da corrida, tratando-se apenas de mais uma etapa a ser vencida. Diferente das corridas de nosso cotidiano, este trabalho teve por propósito direcionar um novo caminho, que dará continuidade em trabalhos posteriores, pois também se iniciou a partir da experiência vivenciada por pesquisadores que se debruçaram anteriormente.

Procuramos ao longo desta pesquisa entender a relação entre dois grandes temas discutidos amplamente nas ciências sociais: os rituais e o sacrifício do corpo, olhando-os para os mesmos com foco na corrida de rua - nosso objeto de estudo. Portanto, a corrida de rua foi por nós compreendida como um fenômeno sociocultural, que apresenta diferentes matizes, mas na atualidade ou contemporaneidade torna-se cada vez mais um fenômeno que se projeta para além dos aspectos fisiológicos, podendo ser entendida como uma prática corporal que envolve as dimensões biológica, psicológica e social.

Iniciamos nossa empreitada numa pesquisa sobre a origem de uma das corridas mais respeitadas entre os corredores de rua, em todo mundo, por sua história e contexto: a maratona. Aprofundamo-nos em desvendar um pouco mais da justificativa da distância de 42.195 metros desta prova. Realizamos um pequeno relato sobre nossa experiência em uma Maratona, na cidade de Buenos Aires.

Descrevemos em breves linhas algumas das primeiras corridas no Brasil, tendo como principal prova a corrida de São Silvestre e também as corridas de maior tradição em Brasília, citando a primeira Maratona de Brasília (realizada em 1984), a Corrida de Reis (através de um diário de campo e registros fotográficos) e as mais recentes Meia Maratona Internacional da Caixa e a Volta do Lago.

Chegamos então ao nosso principal desafio: debruçarmo-nos em desvendar a relação entre o sacrifício do corpo e os rituais associados à corrida de rua no cotidiano de alguns atletas amadores, que através de uma entrevista 
semiestruturada pudemos entender um pouco mais dessa relação e claro, baseado numa ampla literatura sobre estes temas.

Para tal, nos deparamos num desafio inicial: ao descobrir que poucos estudos foram feitos abraçando estas temáticas, precisaríamos de mais elementos a fim de fundamentar nosso trabalho. Desta forma, autores das ciências sociais e publicações em revistas nacionais de educação física se tornaram elementos chaves para o aprofundamento da literatura.

No cotidiano dos atletas amadores que praticam a corrida como prática corporal em suas rotinas, entendemos que como elemento subjetivo e a partir de um olhar mais sensível a estas categorias, o sacrifício do corpo e os elementos que compõem os rituais estão presentes nas corridas de rua, seja num treino cotidiano, numa corrida de cinco quilômetros ou até numa ultramaratona.

Percorremos alguns caminhos a fim de descrever o universo da corrida de rua a partir das experiências vivenciadas por alguns corredores de rua, neste trabalho ainda mais revelado através das entrevistas semiestruturadas. Destacamos aqui que a experiência das entrevistas ultrapassou as expectativas sobre as respostas, que sendo semiestruturadas, nos trouxeram desdobramentos subjetivos de tamanha importância para a compreensão das rotinas de cada corredor entrevistado. Além disso, identificamos e analisamos as categorias ritual e sacrifício, advindos das ciências sociais, na prática cotidiana da corrida de rua.

Entendemos que há muito que ser desvendado ao redor desta prática corporal chamada corrida; entendemos ainda que estes são temas a serem tratados com muito aprofundamento, visto que pouco se tem estudado sobre o assunto. Mas entendemos sobretudo que, na prática, há muito que se atentar com a comunidade de atletas amadores que buscam na corrida uma expectativa de melhora em suas vidas, em busca de maior socialização entre seus pares e em busca de uma vida mais saudável e duradoura.

Percebemos que rituais e sacrifícios fazem parte a todo o momento desta prática corporal. Desde o horário de acordar (para treinar, para correr, para se preparar para uma corrida), até o cuidado com o que se deve usar, vestir, comer, calçar para que se alcance os melhores resultados na corrida. Por mais que o objetivo de percorrer 5, 10, 21 ou 42 quilômetros, seja chegar ao final e colecionar mais uma medalha, este trabalho nos apresenta um universo muito mais amplo: de 
alegrias e frustações, de ansiedades e de anseios de concluir um grande objetivo: chegar onde foi planejado com êxito e pensar na próxima corrida!

E desta forma não apenas os treinos, não apenas o investimento financeiro, não apenas as vaidades que o mercado consumidor oferece aos atletas amadores, mas toda conexão existente entre a rotina cotidiana em busca da superação de seus objetivos, que aqui chamamos de ritual, adquirem uma importância de grau maior.

A dor, o sofrimento, o desconforto físico e mental enfrentados em suas rotinas, traduzidos para nós como os sacrifícios do corpo, não são um impedimento para seguir em frente, quilômetros após quilômetros.

Esperamos, finalmente, que novas pesquisas em torno da corrida de rua, um fenômeno sociocultural em crescimento nesta cidade e também no Brasil, possam tomar atenção de outros pesquisadores e esperamos também contribuir com tais pesquisas. 


\section{REFERÊNCIAS BIBLIOGRÁFICAS}

ALBINO, Beatriz Staimbach; VAZ, Alexandre Fernandez. O corpo e as técnicas para o embelezamento feminino: esquema da indústria cultural na Revista Boa Forma. Revista Movimento, Porto Alegre, v. 14, n. 01, p. 199-223, janeiro/abril, 2008;

BITENCOURT, Antonio Galdino et al. Ritual olímpico e os mitos da modernidade: implicações midiáticas na dialética universal/local. Pensar a Prática, v. 8, n. 1, p. 2136, 2006;

CAVALCANTI, Maria Laura Viveiros de Castro. Luzes e sombras no dia social: o símbolo ritual em Victor Turner. Revista Horizontes Antropológicos, Porto Alegre, ano 18, n. 37, p. 103-131, jan./jun. 2012;

COSTA, Grasielle Aires da. O conceito de ritual em Richard Schechner e Victor Turner: análises e comparações. Revista ASPAS, Universidade de São Paulo, vol. 3, n. 1, 2013;

CRUZ, Roberto Cachán. El deporte, proyección, espejo y símbolo cultural: reflexión sobre los deportes de sacrificio y su transmisión de valores en el contexto socioeducativo. Revista Movimento, Porto Alegre, v. 19, n. 03, p. 315-336, jul/set, 2013;

DAMATTA, Roberto. A casa e a rua. Espaço, cidadania, mulher e morte no Brasil. 5ํㅡㄹ. ed., Rio de Janeiro, 1997;

DE OLIVEIRA, Rita de Cássia Magalhães. (ENTRE) LINHAS DE UMA PESQUISA: 0 Diário de Campo como dispositivo de (in) formação na/da abordagem (Auto) biográfica. Revista Brasileira de Educação de Jovens e Adultos, v. 2, n. 4, p. 6987, 2014;

DALLARI, Martha Maria. Corrida de rua: um fenômeno sociocultural contemporâneo. 2009. Tese de Doutorado. Universidade de São Paulo;

DUARTE, Alexandre Ambiel Barros Gil; DE MENEZES, Celso Vianna Bezerra. Antropologia da Performance: a liminaridade $e$ as contradições do social. movimento, v. 2005, p. 2008, 1974;

FLICK, Uwe. Introdução à pesquisa qualitativa. 3ạ. Ed. - Porto Alegre: Artmed, 2009;

FONSECA, João José Saraiva da. Metodologia da pesquisa científica. Fortaleza: UEC, p. 65-75, 2002; 
GALLOWAY, Jeff. Manual de corrida: lições essenciais para correr com saúde e atingir melhor desempenho. São Paulo: Editora Gente, 2009;

GENNEP, Arnold Van. Os ritos de passagem: estudo sistemático dos ritos. $3^{\text {a }}$ ed. Petrópolis, Vozes, 2011;

HANZEN, Roger; VAZ, Alexandre Fernandez. Treino, culto e embelezamento do corpo: um estudo em academias de ginástica e musculação. Revista Brasileira de Ciências do Esporte, Campinas, v. 26. N. 1, p. 135-152, set, 2004;

HUIZINGA, Johan. Homo ludens: o jogo como elemento da cultura. 5edição. São Paulo: Perspectiva, 2014;

MAUSS, Marcel e HUBERT, Henri. Sobre o Sacrifício. São Paulo, SP. Editora Cosac Naify, 2013;

MATTHIESEN, Sara Quenzer; GINCIENE, Guy; DE FREITAS, Fernando Paulo Rosa. Registros da maratona em Jogos Olímpicos para a difusão em aulas de Educação Física. Revista Brasileira de Educação Física e Esporte, v. 26, n. 3, p. 463-471, 2012;

MAFFESOLI, Michel. El tiempo de las tribus: el ocaso del individualismo en las sociedades posmodernas. Siglo xxi, 2004;

MCDOUGALL, Christopher. Nascidos para correr: a experiência de descobrir uma nova vida. São Paulo: Globo, 2010;

DE MELLO, Gláucia Buratto Rodrigues. Dádiva, sacrifício e magia na simbólica espiritualidade eclética. outubro, n. 2015, 2015;

OLIVEIRA, Marcus Aurélio Taborda da; OLIVEIRA, Luciana Paiva Alves de; VAZ, Alexandre Fernandez. Sobre corporalidade e escolarização: contribuições para a reorientação das práticas escolares da disciplina de educação física. Revista Pensar a prática 12/3: 1-12, 2009;

PIERCE, Bill; MURR, Scott; MOSS, Ray. Treine menos, corra mais. São Paulo: Editora Gente, 2009;

PEIRANO, Mariza. Rituais Ontem e hoje. Rio de Janeiro, RJ: Editora Jorge Zahar, 2003;

PIMENTEL, Giuliano Gomes. Ritos e risco na prática do vôo livre. Movimento (ESEF/UFRGS), v. 14, n. 3, p. 13-32, 2008; 
RIGONI, Ana Carolina Capellini. Os usos do corpo: dos sacrifícios "primitivos" às religiões "atuais" - Resenha - Revista da Faculdade de Educação Física da UNICAMP, Campinas, v. 6, n. 1, p. 86-95, jan/abr, 2008;

RODRIGUES, Nuno Simões. Nos 2500 anos da Batalha de Maratona. Humanitas, v. 62 , p. 41-44, 2010;

ROJO, JEFERSON ROBERTO. CORRIDAS DE RUA, SUA HISTÓRIA E TRANSFORMAÇÕES. In: VII Congresso Sulbrasileiro de Ciências do Esporte. 2014;

SANTOS, Suely Xavier dos. Uma leitura sócio-antropológica do sacrifício: Estudo de caso Levítico 6.17-23. Revista Caminhando, v. 16 n. 2, p. 21-30, jul./dez, 2011;

SCALCO, Lucia Mury. Por isso corro demais... Notas etnográficas de uma corredora iniciante. Revista Brasileira de Sociologia da Emoção. RBSE 9 (25): 312-355, Abril de 2010;

SILVA, Alan Camargo e LUDORF, Sílvia Maria Agatti. GENNEP, A. V., Os ritos de passagem. Revista Pensar a Prática, Goiânia, v. 15, n. 4, p. 821-1113, out/dez 2012;

SILVA, Carlos Alberto Figueiredo; VOTRE, Sebastião Josué. Encanto e fascínio: dimensões da sedução na educação. Revista Pensar a prática, 12/3: 1-12, 2009;

THOMANZINI, Samuel Oliveira. Controle de si, dor e representação feminina entre lutadores(as) de mixed martial arts. Revista Pensar a prática 11/3: 281-290, 2008; TORRI, Giselle; BASSANI, Jaison José; VAZ, Alexandre Fernandez. Dor e tecnificação no contemporâneo culto ao corpo. Revista Pensar a Prática. 10/2: 261 273, jul/dez, 2007;

TURNER, Victor Witter. O processo ritual: estrutura e antiestrutura. Petrópolis, RJ: Vozes, 2013;

Dewey, Dilthey e drama: um ensaio em antropologia da experiência (primeira parte). Revista Cadernos de Campo, v. 13, p. 177-185, 1986;

VARELLA, Drauzio. Correr: o exercício, a cidade e o desafio da maratona. $1^{\underline{a}}$ ed. São Paulo: Companhia das Letras, 2015;

VAZ, Alexandre Fernandez. Técnica, Esporte, Rendimento. Revista Movimento, Porto Alegre, v. 7, p. 87-99, 2001;

- Reflexões de passagem sobre o lazer: notas sobre a pedagogia da indústria cultural. Revista Pensar a prática 9/1: 13-26, Jan./Jun, 2006. 


\section{APÊNDICES}

1. Termo de Consentimento Livre e Esclarecido, incluindo direito de uso da imagem;

2. Fotografias e arquivos de pesquisa 


\section{APÊNDICE 1 -Termo de Consentimento Livre e Esclarecido - TCLE}

O(a) Senhor(a) está sendo convidado(a) a participar do projeto "RITOS E SACRIFÍCIOS DO CORPO NAS CORRIDAS DE RUA: RELATOS E SIGNIFICADOS NO COTIDIANO DOS CORREDORES DE RUA". O projeto faz parte do programa de pós-graduação (nível mestrado) da Faculdade de Educação Física da UnB (Universidade de Brasília). Pretende-se, através desta pesquisa, compreender a relação que aproxima o ritual acerca das corridas de rua entre os atletas amadores, considerando o sacrifício corporal dos praticantes e os processos de socialização presentes nesta prática corporal.

Os pesquisadores envolvidos neste projeto são: o aluno, pesquisador Cláudio José de Arruda e sua orientadora Dulce Maria Filgueira de Almeida, ambos do programa de mestrado em Educação Física, linha de pesquisa de Estudos Sociais e Pedagógicos da Educação Física, Esporte e Lazer da Universidade de Brasília. Com eles, se poderá manter contato maiores esclarecimentos pelos telefones ou e-mails que são: (61) 8189-3300 ou claudio77ja@gmail.com (aluno Cláudio Arruda) e/ou (61) 9171-8303 ou dulce.filgueira@gmail.com (Orientadora Dulce Almeida).

Esta pesquisa apresenta riscos mínimos, salvo no caso de constrangimento, no entanto, não é a intenção do pesquisador constranger o pesquisado. Por isso, o pesquisador estará sempre tomando cuidados ao conduzir a pesquisa, pensando sempre na melhor forma de se posicionar perante os pesquisados e na melhor forma de falar com eles (com o intuito de minimizar os riscos). Além disso, o pesquisador se põe à disposição para conversar ou responder a qualquer pergunta que possa a vir a surgir por ocasião da intervenção. Espera-se que você se sinta a vontade durante a entrevista, bem como em outros momentos da pesquisa.

$\mathrm{O}$ (a) senhor(a) receberá todos os esclarecimentos necessários antes e no decorrer da pesquisa e the asseguramos que seu nome não aparecerá, sendo mantido o mais rigoroso sigilo através da omissão total de qualquer informação que permitam identificá-lo(a). Informamos que o(a) senhor(a) pode se recusar a responder (ou participar de qualquer procedimento), podendo desistir de participar da pesquisa em qualquer momento sem nenhum prejuízo para o(a) senhor(a). Caso 
haja algum dano direto ou indireto decorrente de sua participação na pesquisa, você poderá ser indenizado, obedecendo-se às disposições legais vigentes no Brasil.

Os resultados da pesquisa serão divulgados na Universidade de Brasília podendo ser publicados posteriormente. Os dados e materiais utilizados na pesquisa ficarão sob a guarda do pesquisador por um período de no mínimo cinco anos, após isso serão destruídos ou mantidos na instituição. Se o(a) Senhor(a) tiver qualquer dúvida em relação à pesquisa, por favor telefone para: Cláudio Arruda (61) 8189 3300 no horário: 8:00 às 18:00 (de segunda à sexta-feira) ou para Dulce Almeida, na Faculdade de Educação Física da UnB, telefone: (61) 3107-2512 e (61) 9171 8303, no mesmo horário. A ligação poderá ser feita a cobrar.

Este projeto foi aprovado pelo Comitê de Ética em Pesquisa da Faculdade de Ciências da Saúde (CEP/FS) da Universidade de Brasília. O CEP é composto por profissionais de diferentes áreas cuja função é defender os interesses dos participantes da pesquisa em sua integridade e dignidade e contribuir no desenvolvimento da pesquisa dentro de padrões éticos. As dúvidas com relação à assinatura do TCLE ou os direitos do participante da pesquisa podem ser obtidos através do telefone: (61) 3107-1947 ou do e-mail cepfs@unb.br ou cepfsunb@gmail.com, horário de atendimento de 10:00hs às 12:00hs e de 13:30hs às 15:30hs, de segunda a sexta-feira.

Este documento foi elaborado em duas vias, uma ficará com o pesquisador responsável e a outra com o Senhor(a).

Declaro que concordo em participar desse estudo e me foi dada a oportunidade de ler e esclarecer minhas dúvidas quanto ao estudo.

Participante da pesquisa / Nome e assinatura

Pesquisador Responsável / Nome e assinatura

Brasília, de 
APÊNDICE 2 - Fotografias e arquivos de pesquisa

Corrida de Reis 2016 / Corredores Aquecendo

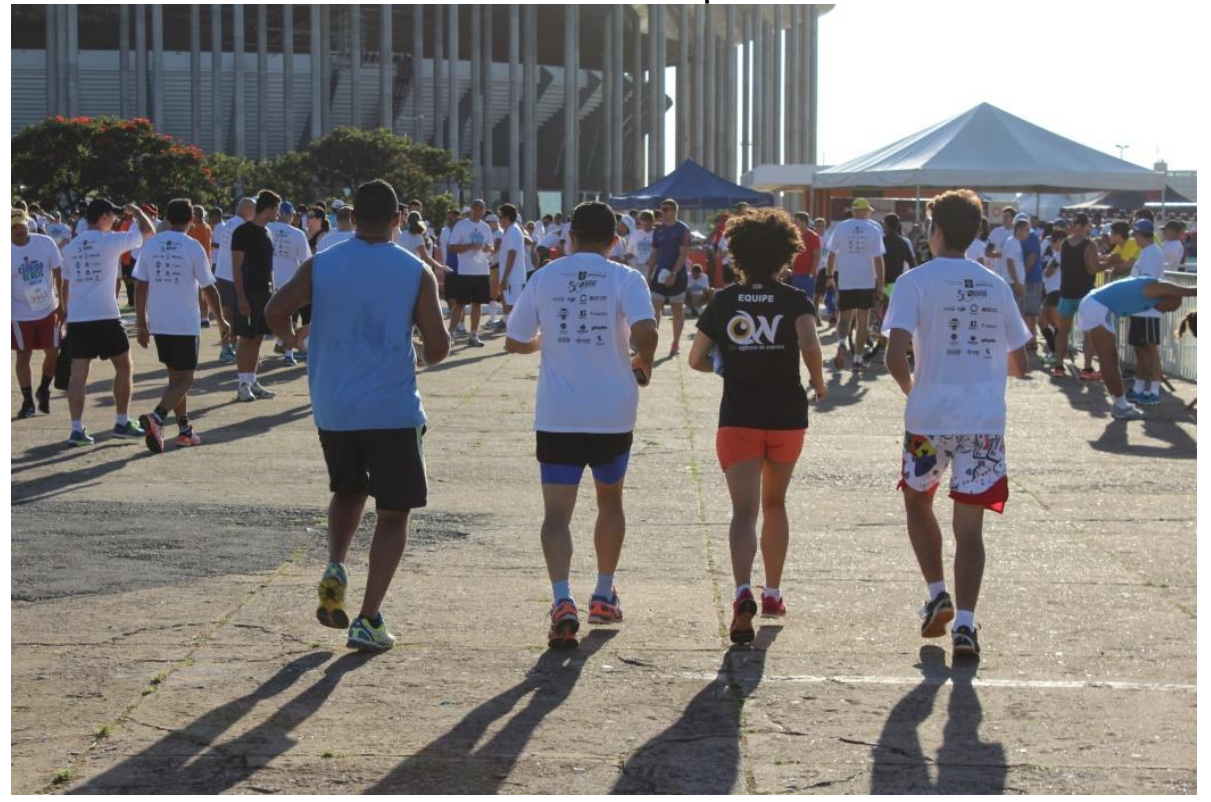

Fonte: autoria própria

Corrida de Reis 2016 / Atletas se registrando através de fotos antes da corrida

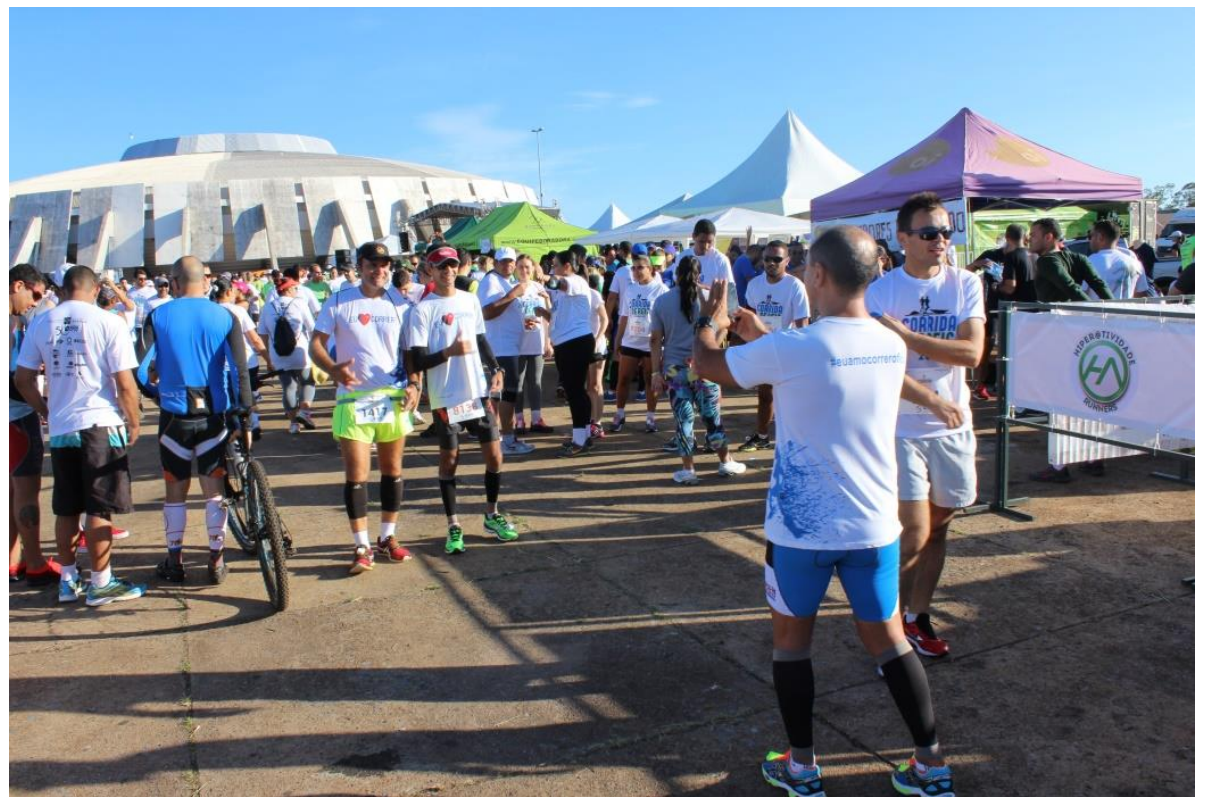

Fonte: autoria própria 
Corrida de Reis 2016 / A expectative da largada do atleta cadeirante à frente dos demais corredores

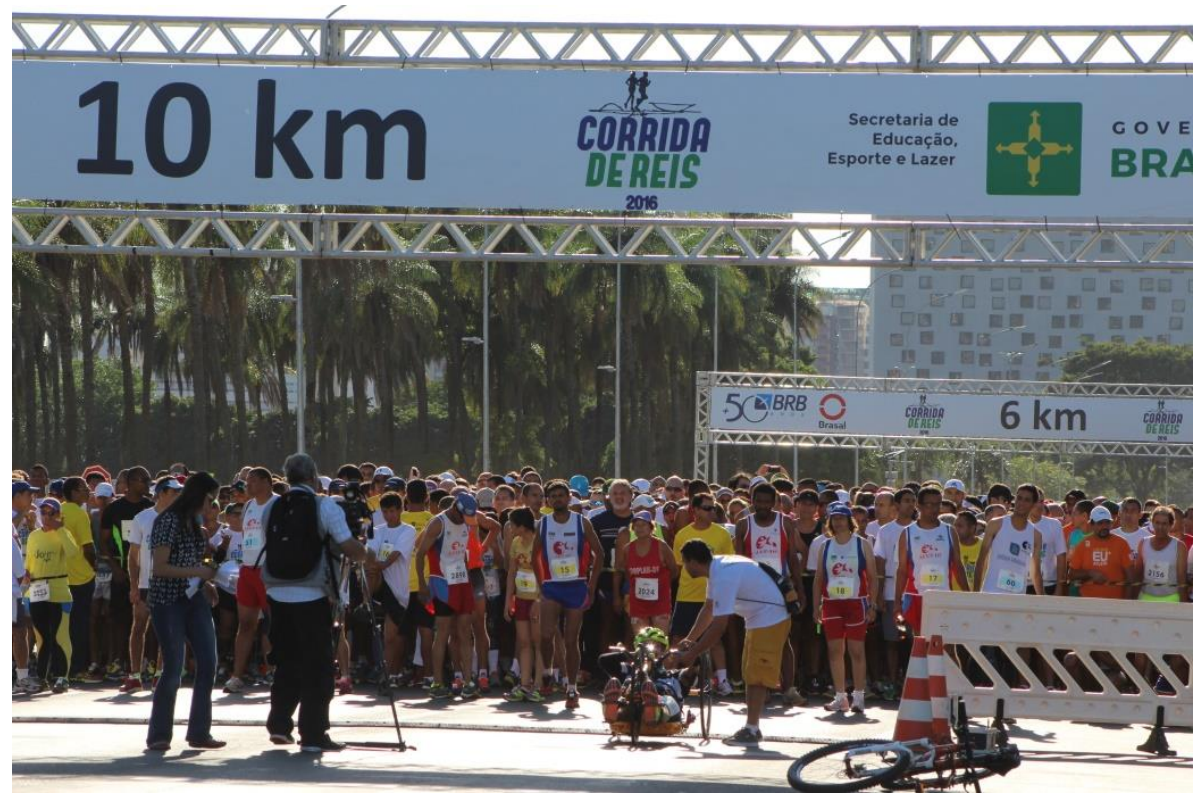

Fonte: autoria própria 


\section{LISTA DE ANEXOS}

Anexo I - Corrida de Reis, 1971 - registro da primeira Corrida de

Reis. .85

Anexo II - Cartaz oficial de divulgação da primeira Maratona ocorrida em Brasília, em 1984 86

Anexo III - Correio Braziliense - Registro da primeira Maratona de Brasília. .87

Anexo IV - Correio Braziliense - Registro da sexta edição da Maratona do aniversário de Brasília em 1996 .88

Anexo V - Cartaz de Divulgação da primeira edição da Ultramaratona Volta do Lago, patrocinada pela Caixa, 2004 .89

Anexo VI - Divulgação da $17^{a}$ edição da Meia Maratona Internacional Caixa, 2016 
Anexo I - Corrida de Reis, 1971 - registro da primeira Corrida de Reis.

\section{CORRIDA DE REIS DARÁ LARGADA AS 20h30m}
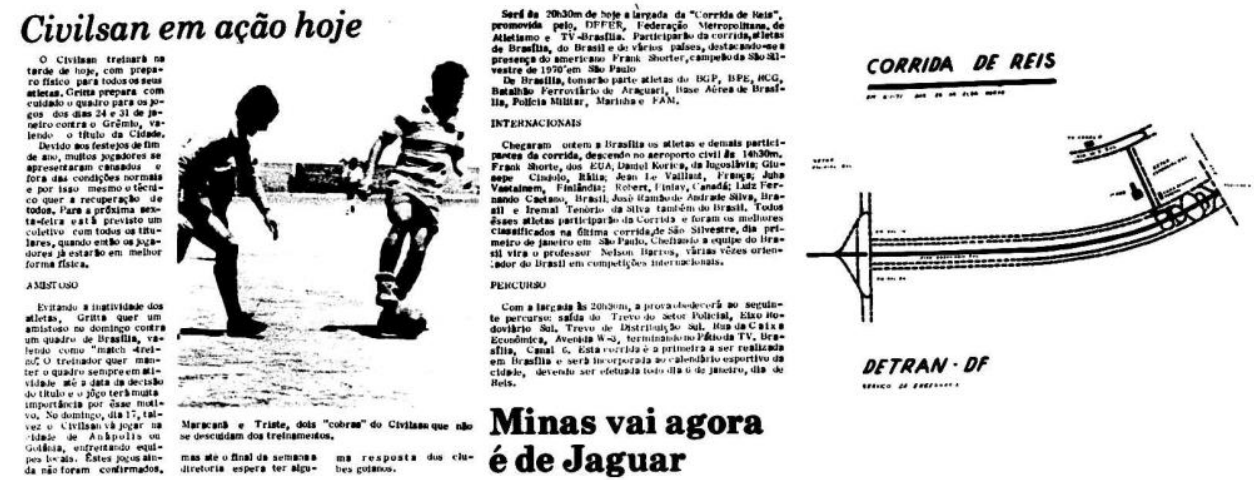

AS COISAS VÃO MUDAR

Minas vai agora de Jaguar

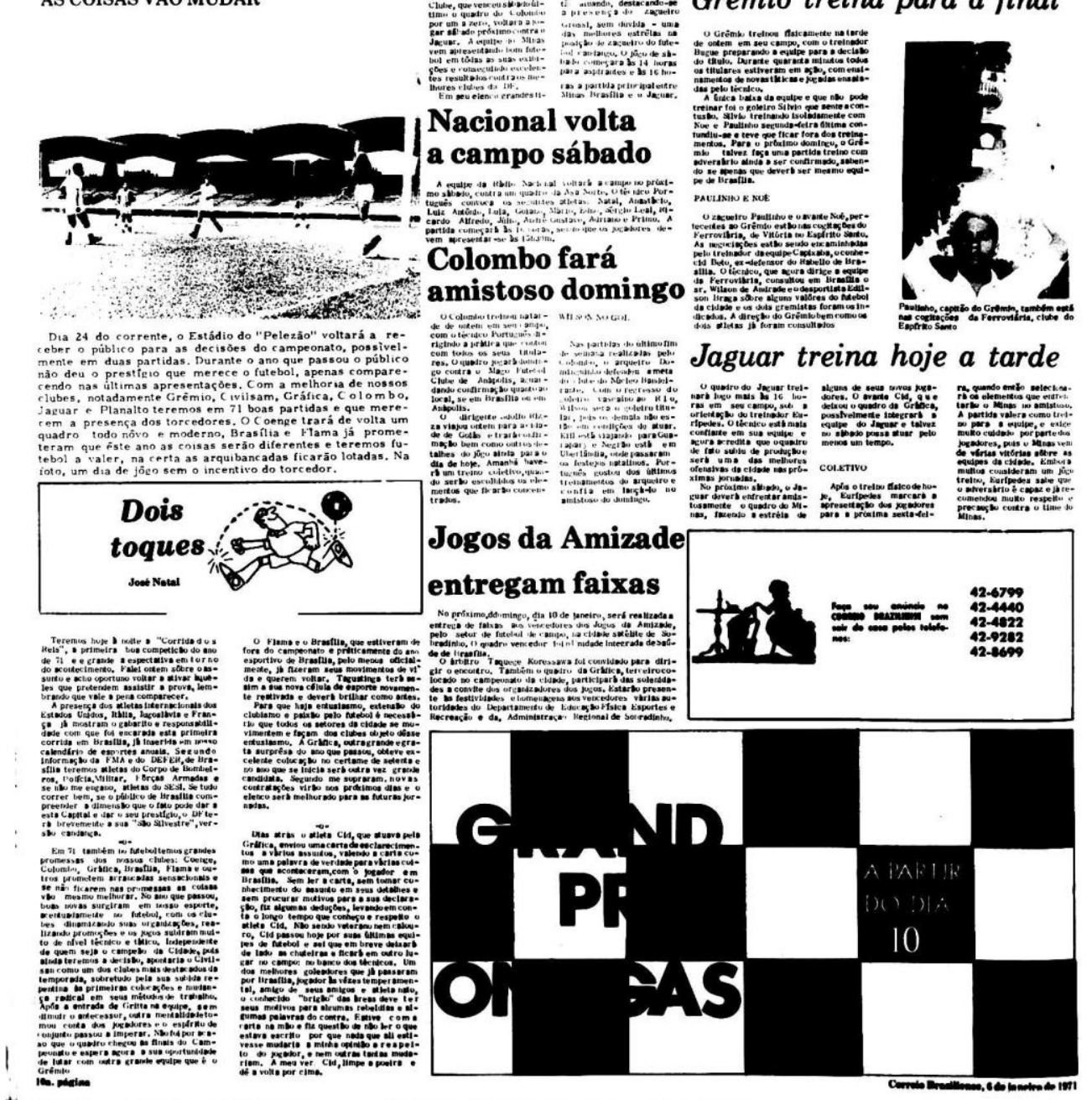
Braziliense).

Fonte: Correio Braziliense (CEDOC - Centro de Documentação do Correio 
Anexo II - Cartaz oficial de divulgação da primeira Maratona ocorrida em Brasília, em 1984.

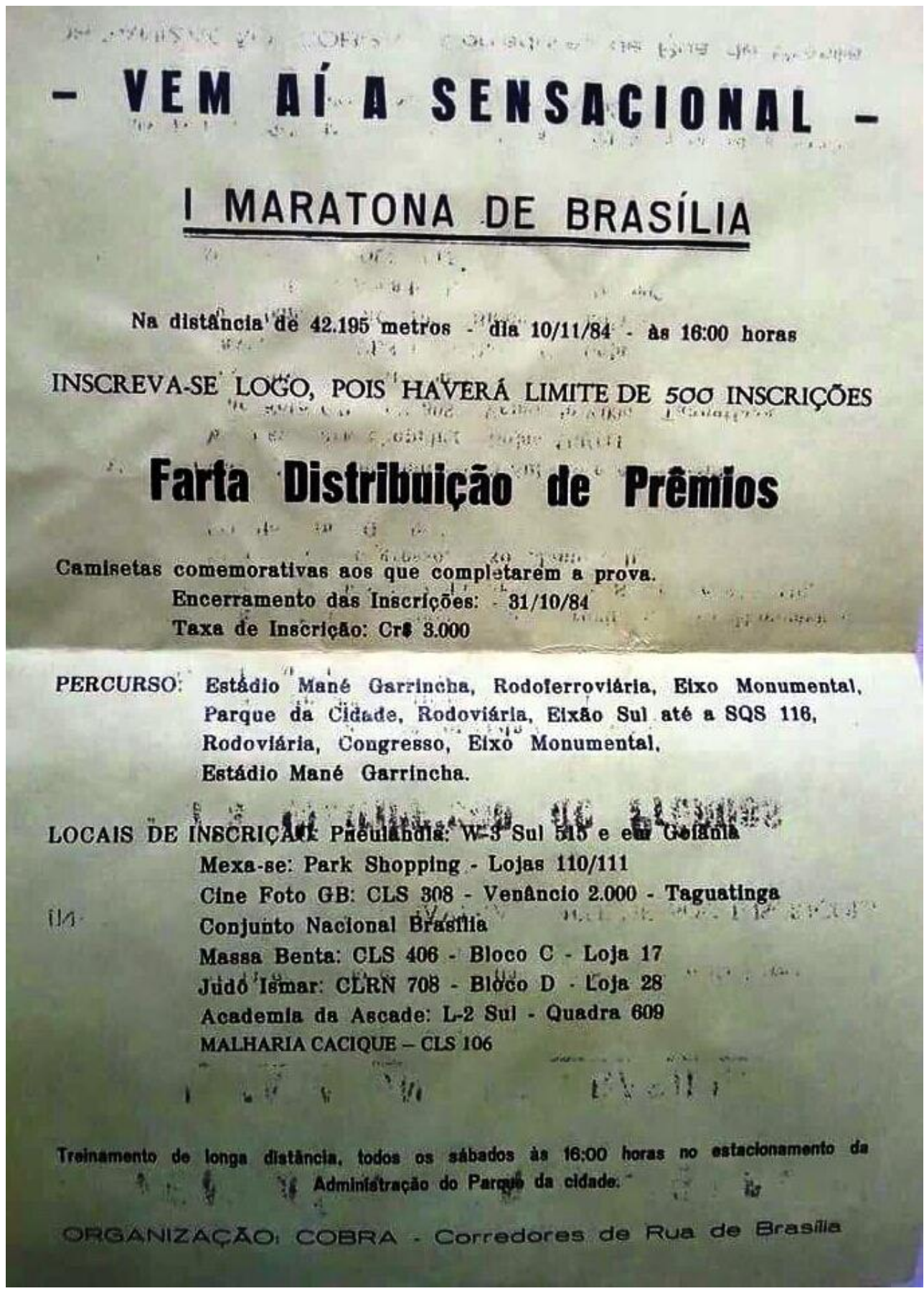

Fonte: arquivo anônimo. 
Anexo III - Correio Braziliense - Registro da primeira Maratona de Brasília.

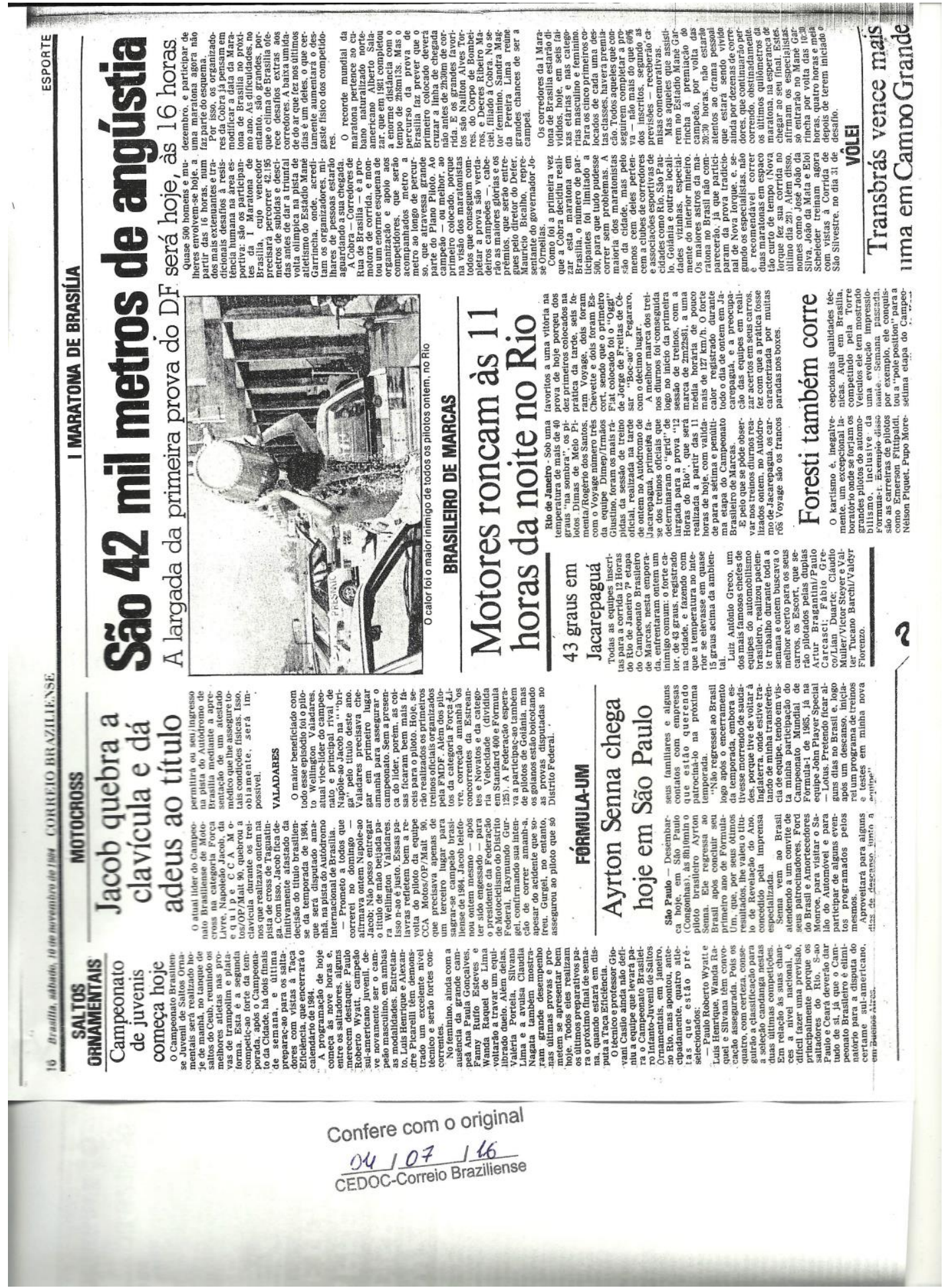

Fonte: Correio Braziliense (CEDOC). 
Anexo IV - Correio Braziliense - Registro da sexta edição da Maratona do aniversário de Brasília em 1996.
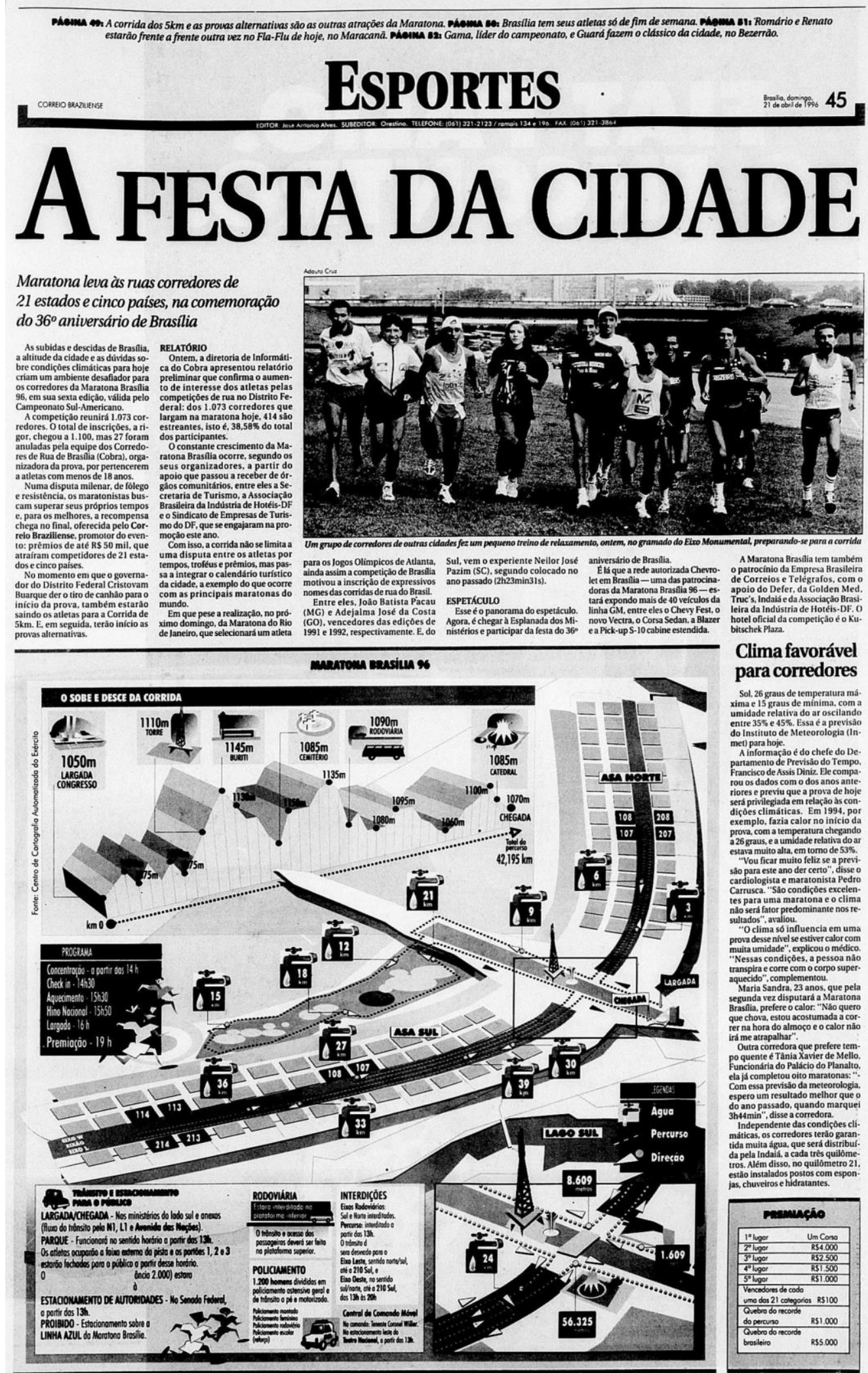

Fonte: Correio Braziliense (CEDOC). 
Anexo V - Cartaz de Divulgação da primeira edição da Ultramaratona Volta do Lago, patrocinada pela Caixa, 2004.
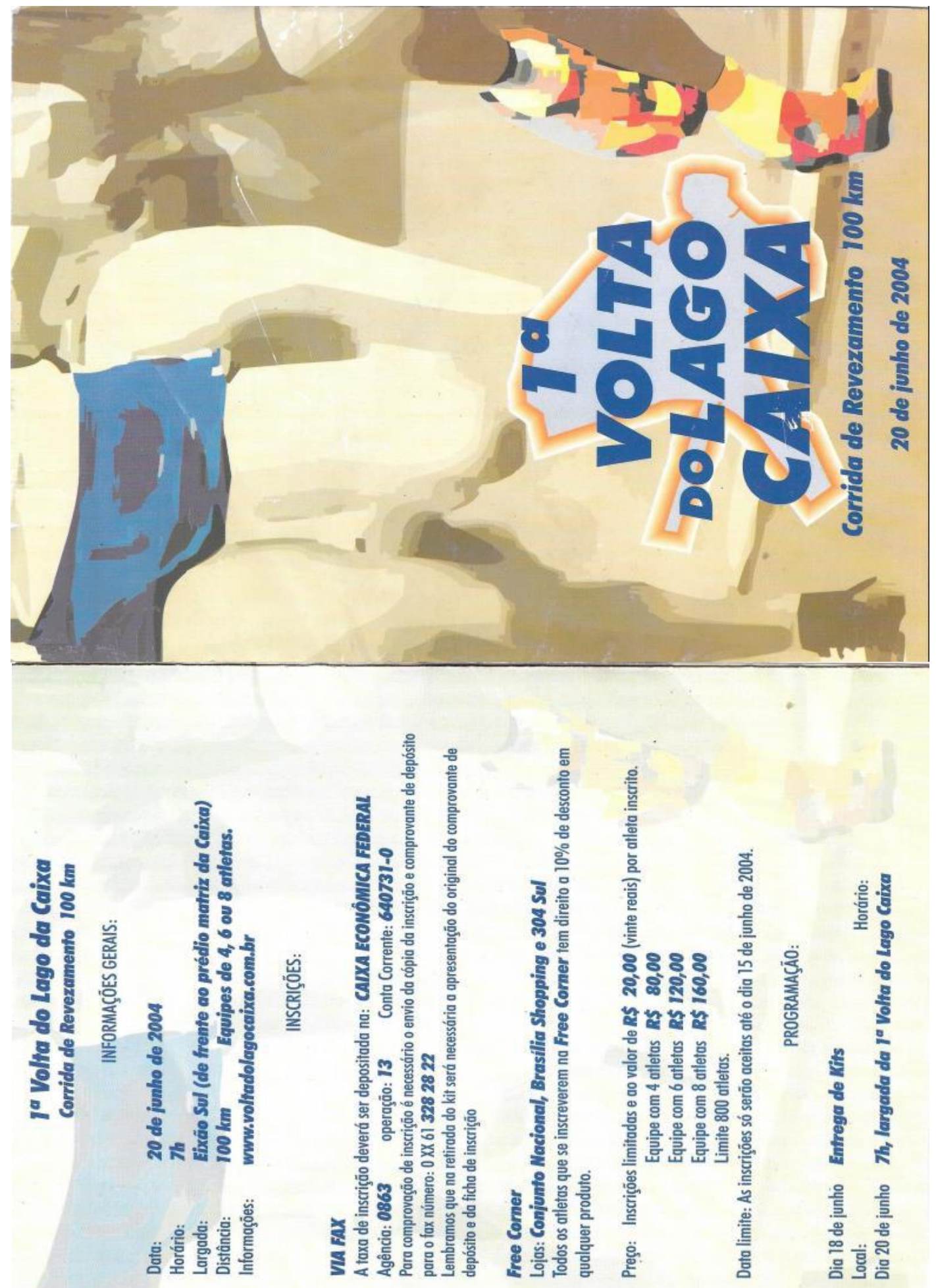

Fonte: AJR Esportes (empresa de Brasília promotora de eventos esportivos). 
ANEXO VI - Divulgação da $17^{a \mathfrak{a}}$ edição da Meia Maratona Internacional Caixa, 2016.

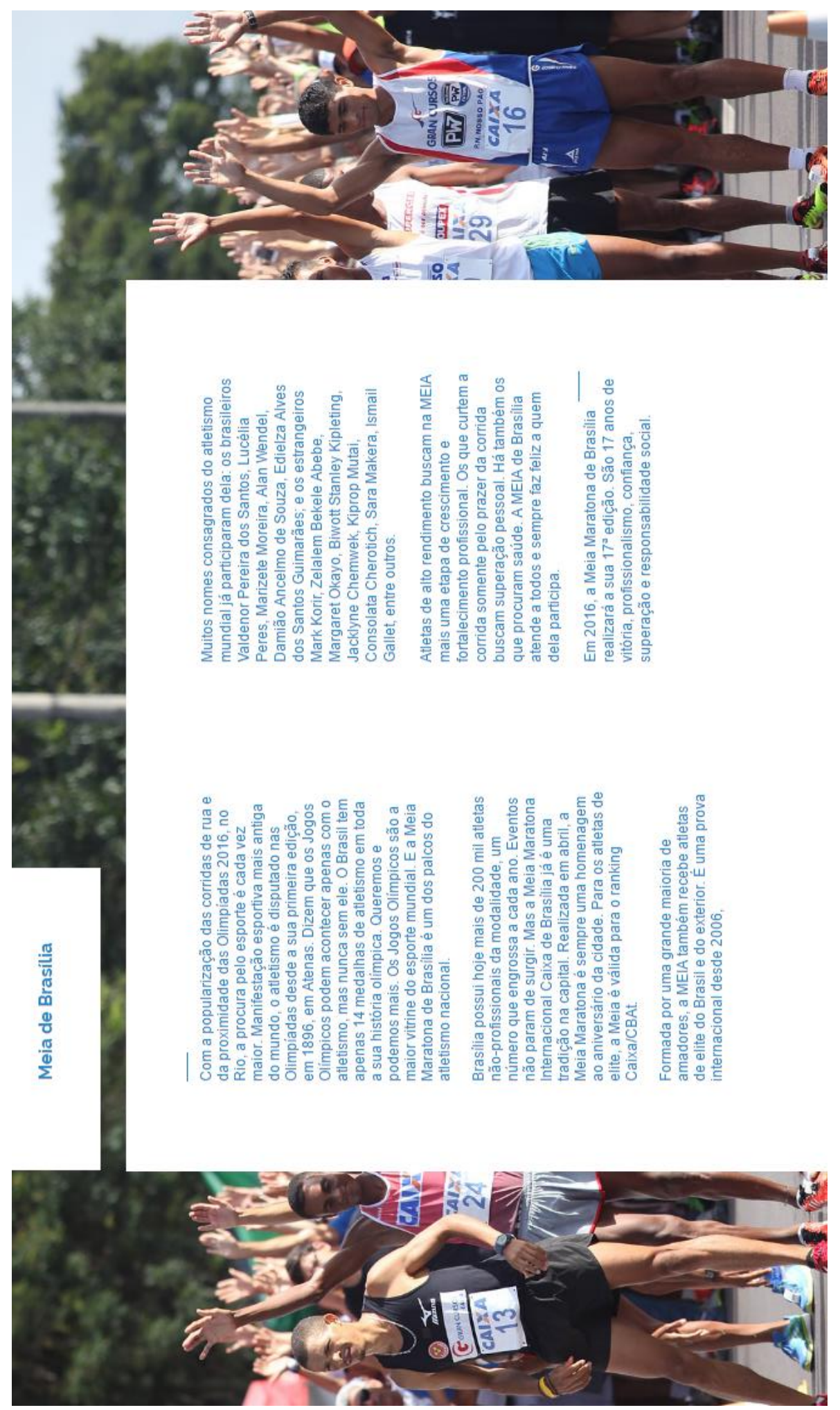

FONTE: http://www.meiamaratonacaixabrasilia.com.br 